Prepared in cooperation with the New Jersey Department of Environmental Protection

Use of a Ground-Water Flow Model to Delineate Contributing Areas to the Puchack Well Field, Pennsauken Township and Vicinity, Camden County, New Jersey

Scientific Investigations Report 2004-5101

U.S. Department of the Interior

U.S. Geological Survey 


\section{Use of a Ground-Water Flow Model to Delineate Contributing Areas to the Puchack Well Field, Pennsauken Township and Vicinity, Camden County, New Jersey}

By Daryll A. Pope and Martha K. Watt

Prepared in cooperation with the

New Jersey Department of Environmental Protection

Scientific Investigations Report 2004-5101 


\section{U.S. Department of the Interior \\ Gale A. Norton, Secretary \\ U.S. Geological Survey \\ Charles G. Groat, Director}

U.S. Geological Survey, Reston, Virginia: 2005

For sale by U.S. Geological Survey, Information Services
Box 25286, Denver Federal Center
Denver, C0 80225
For more information about the USGS and its products:
Telephone: 1-888-ASK-USGS
World Wide Web: http://www.usgs.gov/

Any use of trade, product, or firm names in this publication is for descriptive purposes only and does not imply endorsement by the U.S. Government.

Although this report is in the public domain, permission must be secured from the individual copyright owners to reproduce any copyrighted materials contained within this report. 


\section{Contents}

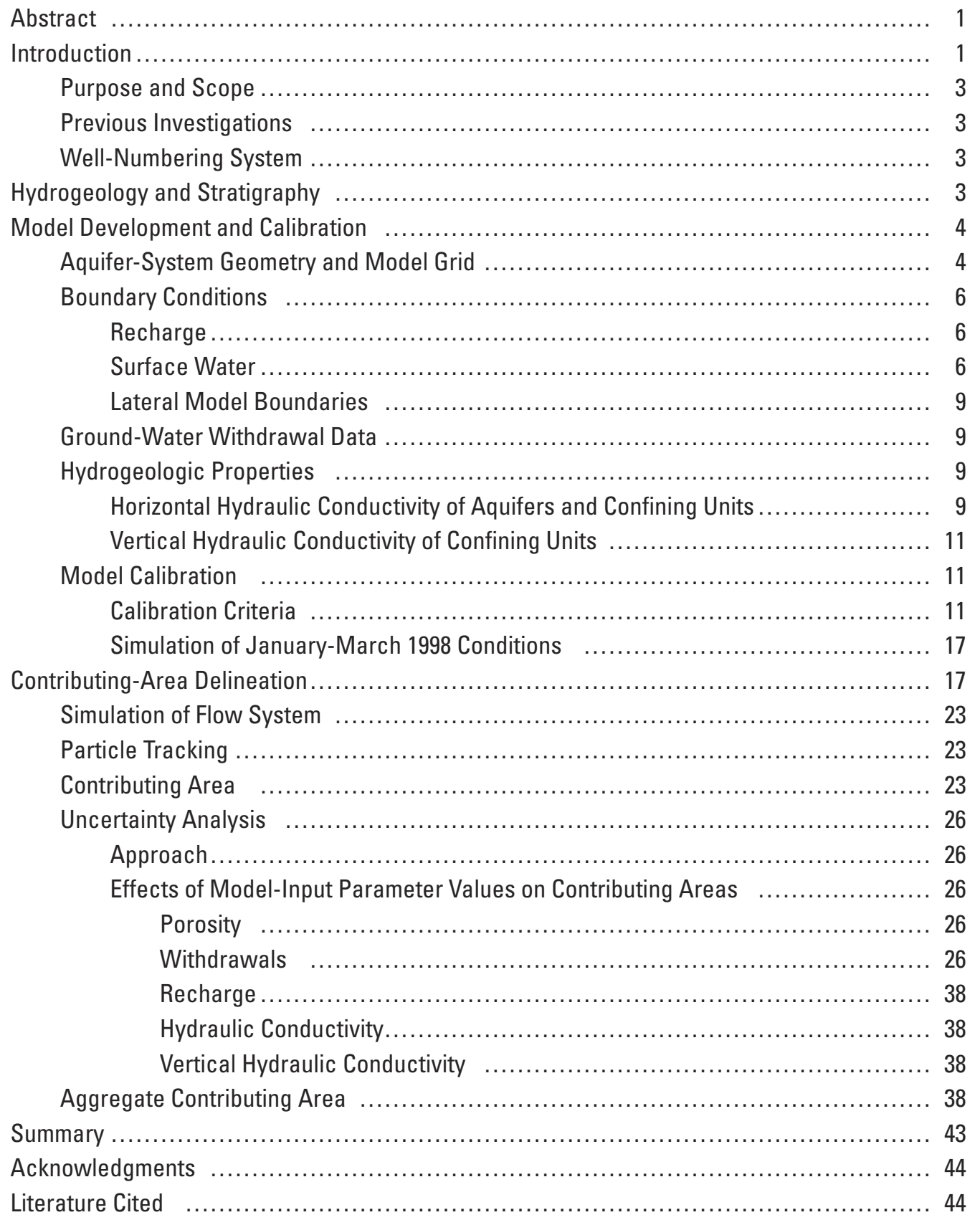




\section{Figures}

1-29. Maps Showing -

1. Location of the local model and ground-water withdrawal data for the delineation simulation, Pennsauken Township and vicinity, Camden County,

New Jersey.

2. Ground-water flow model grid used for contributing-area delineation, and outcrop areas of the Potomac-Raritan-Magothy aquifer system.............. 5

3. Recharge used in the ground-water flow model. ......................... 7

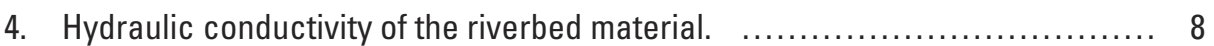

5. Average ground-water withdrawals during January-March 1998 in the

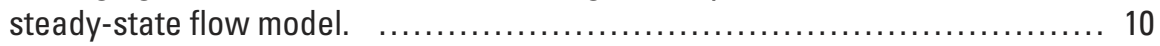

6. Horizontal hydraulic conductivity of the Lower aquifer of the Potomac-Raritan-Magothy aquifer system in the ground-water flow model. $\quad \ldots 12$

7. Vertical hydraulic conductivity in confining unit $\mathrm{C}-1$ in the ground-water flow model.

8. Vertical hydraulic conductivity in confining unit C-2a in the ground-water flow model

9. Vertical hydraulic conductivity in confining unit $\mathrm{C}-2 \mathrm{~b}$ in the ground-water flow model

10. Location of wells used to calibrate vertical hydraulic conductivity in the ground-water flow model

11. Simulated and measured potentiometric surfaces and residuals in the Middle aquifer of the Potomac-Raritan-Magothy aquifer system, January-March 1998.

12. Simulated and measured potentiometric surfaces and residuals in the Lower aquifer of the Potomac-Raritan-Magothy aquifer system, January-March 1998.

13. Differences between simulated and measured gradients across confining units C-2a and C-2b, January-March 1998.

14. Simulated contributing area to the Puchack well field in the delineation simulation

15. Simulated contributing area to individual wells in the Puchack well field 25

16. Simulated contributing area to Puchack well field when porosity is increased to 25 percent in aquifers and 30 percent in confining units.

17. Simulated contributing area to Puchack well field when porosity is decreased to 15 percent in aquifers and 20 percent in confining units.

18. Simulated contributing area to Puchack well field when withdrawals at the Morris/Delair well field are distributed in the northern part of the well field. 30

19. Simulated contributing area to Puchack well field when withdrawals at the Morris/Delair well field are distributed in the southern part of the well field 31

20. Simulated contributing area to Puchack well field when recharge is increased 29 percent.

21. Simulated contributing area to Puchack well field when recharge is decreased 32 percent.

22. Simulated contributing area to Puchack well field when the hydraulic conductivity of the Middle aquifer of the Potomac-Raritan-Magothy aquifer system is increased 50 percent 
23. Simulated contributing area to Puchack well field when the hydraulic conductivity of the Middle aquifer of the Potomac-Raritan-Magothy aquifer system is decreased 28 percent.

24. Simulated contributing area to Puchack well field when the hydraulic conductivity of the Lower aquifer of the Potomac-Raritan-Magothy aquifer system is increased 23 percent .... 36

25. Simulated contributing area to Puchack well field when the hydraulic conductivity of the Lower aquifer of the Potomac-Raritan-Magothy aquifer system is decreased 19 percent 37

26. Simulated contributing area to Puchack well field when the vertical hydraulic conductivity of the Middle aquifer of the Potomac-Raritan-Magothy aquifer system is increased 1,900 percent.

27. Simulated contributing area to Puchack well field when the vertical hydraulic conductivity of the Middle aquifer of the Potomac-Raritan-Magothy aquifer system is decreased 78 percent.

28. Number of model runs in which each area contributed flow to the Puchack well field in the uncertainty analysis.

29. Simulated aggregate contributing area to the Puchack well field including the effects of uncertainty analysis.

\section{Tables}

1. Well-construction data for wells used in the ground-water flow model, Pennsauken Township and vicinity, Camden County, New Jersey

2. Local hydrogeologic framework used in this study, corresponding model layers used in the ground-water flow model, and comparison to the regional hydrogeologic framework as described in previous studies $\ldots \ldots \ldots \ldots \ldots \ldots \ldots \ldots$

3. Ground-water withdrawal data used in the ground-water flow model $\ldots \ldots \ldots \ldots \ldots 11$

4. Wells with aquifer-test data and estimates of hydraulic conductivity .............. 13

5. Simulated and measured head differences at nested wells. .................... 22

6. Model runs and parameter changes in the ground-water flow model .............. 27 


\section{Conversion Factors}

\begin{tabular}{lcl}
\hline Multiply & By & To obtain \\
\hline inch (in.) & Length & \\
foot (ft) & 2.54 & centimeter $(\mathrm{cm})$ \\
\hline \multicolumn{3}{l}{ meter $(\mathrm{m})$}
\end{tabular}

Vertical coordinate information is referenced to the National Geodetic Vertical Datum of 1929 (NGVD of 1929).

Horizontal coordinate information is referenced to the North American Datum of 1983 (NAD 83).

Altitude, as used in this report, refers to distance above the vertical datum. 


\title{
Use of a Ground-Water Flow Model to Delineate Contributing Areas to the Puchack Well Field, Pennsauken Township and Vicinity, Camden County, New Jersey
}

\author{
By Daryll A. Pope and Martha K. Watt
}

\section{Abstract}

The New Jersey Department of Environmental Protection (NJDEP) Well Head Protection Program, developed in response to the 1986 Federal Safe Drinking Water Act Amendments, requires delineation of Well Head Protection Areas (WHPA's), commonly called contributing areas, for all public and non-community water-supply wells in New Jersey. Typically, WHPA's for public community water-supply wells in New Jersey are delineated using a two-dimensional ground-water flow model incorporating the regional hydraulic gradient; however, NJDEP guidelines allow for the use of a three-dimensional flow model to delineate contributing areas to wells in complex hydrogeologic settings.

The Puchack well field in Pennsauken Township, Camden County, N.J., is an area of strong hydraulic connection between the Lower aquifer of the PotomacRaritan-Magothy aquifer system and the Delaware River. Interactions among and within the public-supply well fields in the area are complex.

To delineate the contributing area to the Puchack well field, the U.S. Geological Survey, in cooperation with the NJDEP, developed an 11-layer ground-water flow model of the Potomac-Raritan-Magothy aquifer system in the Pennsauken Township area to simulate flow in the vicinity of the well field. The model incorporates the interaction between the aquifer system and the Delaware River, and includes boundary flows from an existing regional model of the Camden area. Recharge used in the model ranged from 4.5 to 14 inches per year, and horizontal hydraulic conductivity ranged from 50 to 250 feet per day. Values of vertical hydraulic conductivity ranging from 0.001 to 0.5 feet per day were assigned to zones created on the basis of variations in hydrogeologic conditions observed in geophysical logs from wells.

A steady-state simulation was used to calibrate the model to synoptic water-level data collected in March 1998. Near the Puchack well field, simulated heads generally were within 1 foot of the measured heads in both the Middle and Lower aquifers. Simulated water-level differences across the confining units at most of the nested wells were within \pm 0.5 feet of the differences calculated from measured water levels.

The existing flow model was modified to meet NJDEP guidelines for delineating contributing areas in complex hydrogeologic settings. These modifications included rediscretizing the model grid to a finer grid and preparing the water-use data set for use in the rediscretized model. The contributing area to the Puchack well field was delineated by means of particle tracking.

An uncertainty analysis was conducted in which 36 model-input parameters were both increased and decreased until the resulting change in simulated heads exceeded the model-calibration criterion of \pm 5 feet at any model cell. Porosity most affected the size and shape of the contributing area. The distribution of withdrawals at the Morris/Delair well field and variations in recharge affected both the size and shape of contributing area to the Puchack well field and the source of water to the Puchack wells.

The results of the uncertainty analysis were combined to determine the "aggregate" contributing area to the Puchack well field - a composite of areas on the land surface that contributed flow to the Puchack well field in less than 12 years in any uncertainty simulation. The shape of the aggregate contributing area was most similar to that associated with a reduction in porosity, which indirectly affected the size and shape of the contributing areas by changing travel time.

\section{Introduction}

The 1986 Federal Safe Drinking Water Act Amendments (Section 1428, P.L. 93-523, 42 USC 300 et seq.) directed all States to develop a Well Head Protection Program for all public community and non-community water-supply wells. In 1991, a Well Head Protection Program was approved in New Jersey that aims to prevent contamination of the ground-water resource, which provides drinking water to approximately 
42 percent of New Jersey's population. Delineation of a Well Head Protection Area (WHPA), or the area from which a well draws its water within a specific time frame, is one aspect of the Well Head Protection Program. Areas designated as WHPA's become a priority for efforts to prevent and mitigate ground-water contamination (Spayd and Johnson, 2003).

The New Jersey Department of Environmental Protection (NJDEP) delineated WHPA's for all water-supply wells in New Jersey. Each WHPA consists of three "tiers" representing the time of travel to the well. The travel times associated with each of the three tiers are shown below.

\section{Tier $1 \quad 0$ to 2 years}

Tier 2 greater than 2 years to 5 years

Tier 3 greater than 5 years to 12 years
The NJDEP delineated WHPA's (contributing areas) for public community water-supply wells using the "combined model/CFR method," which combines a Calculated Fixed Radius (CFR) analysis and a two-dimensional flow model. The CFR analysis defines a radius around the well on the basis of pumping rate, time of travel, effective porosity, and aquifer thickness. The "combined model/CFR method" combines the CFR analysis with a two-dimensional flow model to incorporate the hydraulic gradient, aquifer transmissivity, saturated thickness, and anisotropy. The State guidelines also allow, however, for the use of a three-dimensional ground-water flow model (an "advanced delineation") in areas where hydrologic conditions are complex (Spayd and Johnson, 2003), such as the Pennsauken Township area in Camden County, N.J. (fig. 1).

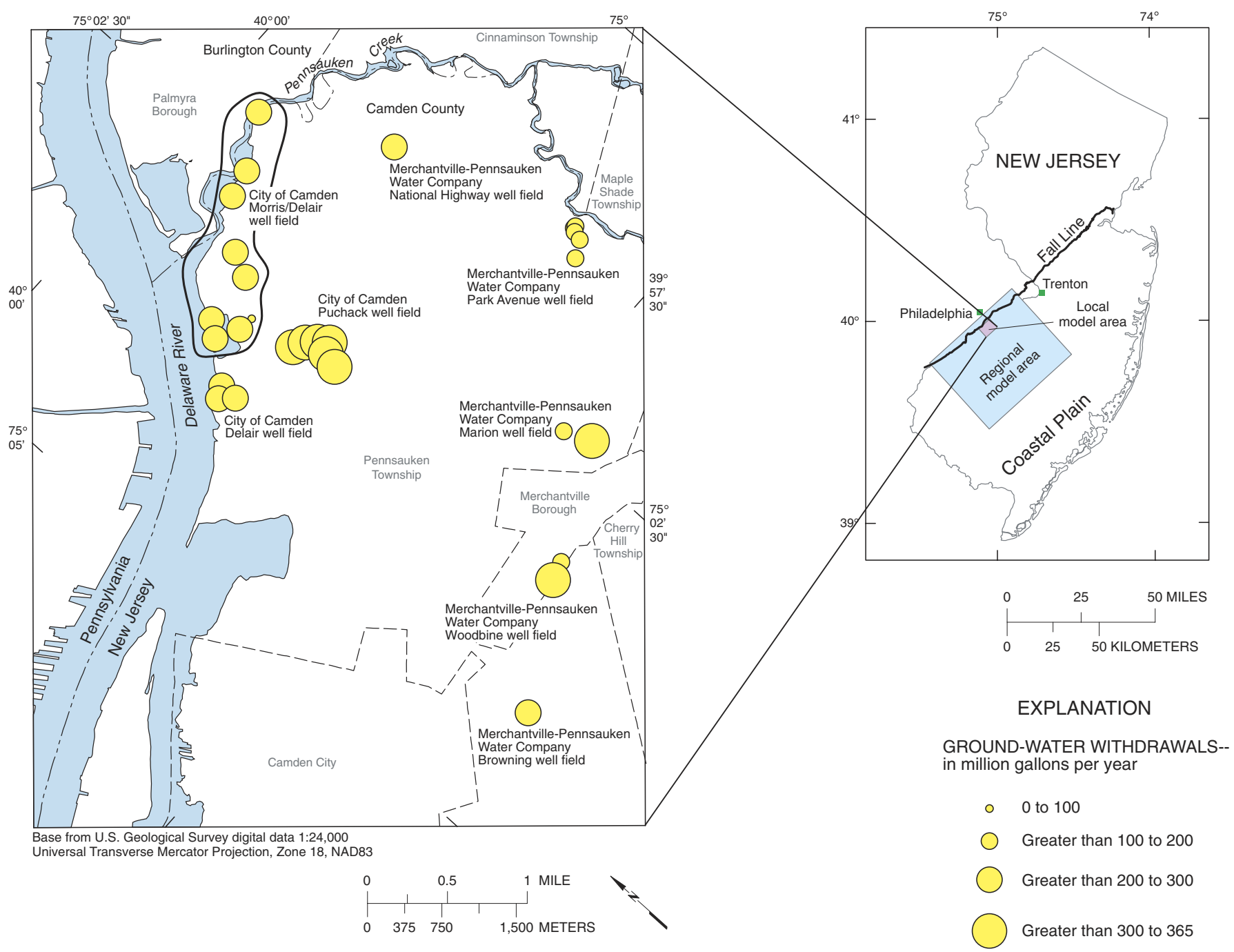

Figure 1. Location of the local model and ground-water withdrawal data for the delineation simulation, Pennsauken Township and vicinity, Camden County, New Jersey. 
The Potomac-Raritan-Magothy aquifer system has been an important source of water supply in northwestern Camden County for many years. In the Pennsauken Township area, this aquifer system is the source of potable water to the City of Camden and the Merchantville-Pennsauken Water Company. As part of the effort to maintain the quality of the water supply, the U.S. Geological Survey (USGS), in cooperation with the NJDEP, delineated the contributing area to the Puchack well field using a three-dimensional ground-water flow model.

\section{Purpose and Scope}

This report documents the delineation of the contributing area to the Puchack well field in Pennsauken Township, New Jersey, using a three-dimensional ground-water flow model. Hydrogeology, stratigraphy, and hydraulic properties of the Potomac-Raritan-Magothy aquifer system are described, and ground-water withdrawal data and estimates of ground-water recharge rates are presented. The report describes the approach used to calibrate the flow model and the results of the model calibration. The flow model was calibrated using water levels measured in March 1998 at 78 wells and vertical differences in water levels measured in 15 nests of wells completed in different aquifers. The flow model is used to delineate the contributing area to the Puchack well field using particle-tracking analysis that calculates the travel times of water to wells. Contributing areas with travel times of 2,5, and 12 years were estimated and the effects of variability in model parameters on the contributing-area size and shape were evaluated. Thirty-six model runs were done in which parameters such as porosity, hydraulic conductivity, and recharge were systematically varied until simulated water levels changed $5 \mathrm{ft}$ from calibrated values. Results of uncertainty analysis, done to test the sensitivity of the model and obtain conservative estimates of the contributing areas to the wells, are used to create an aggregate contributing area for the Puchack well field (a composite of areas on the land surface that contributed flow to the Puchack well field in less than 12 years in any uncertainty simulation).

\section{Previous Investigations}

The hydrogeologic framework of the Coastal Plain and ground-water flow in the vicinity of Pennsauken Township are described in several regional studies. Zapecza (1989) describes the hydrogeologic framework of the New Jersey Coastal Plain. Martin (1998) describes ground-water flow in the New Jersey Coastal Plain. Farlekas and others (1976) describe the hydrogeology of Camden County. Navoy and Carleton (1995) describe the hydrogeology of the Camden County area and present a simulation of the regional ground-water-flow system that provides lateral and vertical boundary flows for the local model described in this report. Walker and Jacobsen (2004) present the stratigraphy of the Pennsauken area along with water-level and water-quality data.

\section{Well-Numbering System}

The well-numbering system used in this report consists of a county-code number followed by a sequence number of the well within the county. County codes used in this report are 5 for Burlington County and 7 for Camden County. For example, well number 7-528 represents the 528th well inventoried in Camden County. Construction details for wells referred to in this report are shown in table 1 (at the end of the report).

\section{Hydrogeology and Stratigraphy}

The Potomac-Raritan-Magothy aquifer system is composed of the wedge-shaped sequence of Cretaceous sediments that make up the Potomac Group and the Raritan and Magothy Formations. These sediments constitute sand and gravel aquifers with intervening silt and clay confining units that thicken and dip from the western edge of the Coastal Plain at the Fall Line toward the southeast (Zapecza, 1989). The sediments are of fluvial-deltaic-marginal marine origin (Farlekas and others, 1976) and represent a complex depositional and erosional environment. The basal unit of the Potomac Group lies directly on the erosional, pre-Cretaceous bedrock surface.

The hydrogeology and stratigraphy of the PotomacRaritan-Magothy aquifer system in the study area as described in detail by Walker and Jacobsen (2004) are compared to the previously described hydrogeologic framework of the Coastal Plain (Navoy and Carleton, 1995; Zapecza, 1989; Farlekas and others, 1976) in table 2.

In previous studies of the area, the Potomac-RaritanMagothy aquifer system has been described as consisting of the Upper, Middle, and Lower aquifers and two intervening confining units (table 2). The Upper aquifer consists of sands of the Magothy Formation, and the Middle and Lower aquifers are composed of sands of the Raritan Formation and Potomac Group. These sediments crop out as thin bands along both sides of the Delaware River in Pennsylvania and New Jersey and are exposed in the bed of the Delaware River through fluvial dissection and dredging (fig. 2). In downdip areas to the east, the aquifer system is overlain the Merchantville-Woodbury confining unit.

In Pennsauken Township and vicinity, permeable layers of sand and gravel that make up the Pennsauken Formation and Quaternary deposits cap the outcrops of the Cretaceous sediments that form the Potomac-Raritan-Magothy aquifer system (Farlekas and others, 1976) throughout most of their extent. Sands and gravels of the Pennsauken Formation are believed to have been deposited in a fluvial environment in which a series of downcutting channels were incised into the underlying sediments (Owens and Minard, 1979). The Quaternary deposits grade from gravel and gravelly sand at Trenton, N.J., to clayey silt at Philadelphia, Pa.; the differences in these sediments probably represent a change in depositional environment. The Tertiary and Quaternary surficial units are 
Table 2. Local hydrogeologic framework used in this study, corresponding model layers used in the groundwater flow model, and comparison to the regional hydrogeologic framework as described in previous studies, Pennsauken Township and vicinity, Camden County, New Jersey.

\begin{tabular}{|c|c|c|c|c|}
\hline \multirow{2}{*}{$\begin{array}{c}\begin{array}{c}\text { Previously described } \\
\text { framework } \\
\text { (5 layers) }\end{array} \\
\text { Hydrogeologic unit }\end{array}$} & \multicolumn{4}{|c|}{ Framework (11 layers) used in the ground-water flow model in this report } \\
\hline & Model layer & $\begin{array}{l}\text { Model-layer } \\
\text { designation }\end{array}$ & $\begin{array}{c}\text { Model-layer } \\
\text { number }\end{array}$ & Major hydrogeologic unit \\
\hline Upper aquifer & Aquifer & A-1 & 1 & Upper aquifer \\
\hline Confining unit & Confining unit & $\mathrm{C}-1$ & 2 & Confining unit \\
\hline \multirow{3}{*}{ Middle aquifer } & Upper sand & A-2a & 3 & \\
\hline & Interbedded confining unit & A-2c1 & 4 & Middle aquifer \\
\hline & Lower sand & $A-2 b$ & 5 & \\
\hline \multirow{3}{*}{ Confining unit } & Upper confining unit & $\mathrm{C}-2 \mathrm{a}$ & 6 & Confining unit \\
\hline & Intermediate sand & $\mathrm{C}-2 \mathrm{AI}$ & 7 & \\
\hline & Lower confining unit & $\mathrm{C}-2 \mathrm{~b}$ & 8 & \\
\hline \multirow{3}{*}{ Lower aquifer } & Upper zone & A-3a & 9 & Lower aquifer \\
\hline & Middle zone & $A-3 b$ & 10 & \\
\hline & Lower zone & $A-3 c$ & 11 & \\
\hline Bedrock confining unit & Bedrock confining unit & & & Underlying clay or bedrock \\
\hline
\end{tabular}

hydraulically connected to the underlying Cretaceous sediments and, therefore, are considered to be part of the PotomacRaritan-Magothy aquifer system.

Because of the depositional environment of the sediments that comprise the aquifer system, discontinuities in individual units are common. Throughout the thickness of the Cretaceous sediments, channels have been cut and filled. Thus, major confining units can contain sand lenses that are local waterbearing zones, and aquifers can contain clay lenses that serve as local confining units. Major confining units also pinch out in some areas. As a result, the hydraulic connections among the sedimentary units can be complex.

\section{Model Development and Calibration}

A three-dimensional, finite-difference ground-water flow model was used to simulate ground-water flow in the Potomac-Raritan-Magothy aquifer system in Pennsauken Township and surrounding areas. The ground-water flow system was simulated using the USGS modular model MODFLOW-96, developed by Harbaugh and McDonald (1996). The Flow and Head Boundary (FHB1) Package (Leake and Lilly, 1997) was used to input the boundary flows from a regional model of the Camden area (Navoy and Carleton, 1995). For this report, the flow model (fig. 1) was calibrated using average-withdrawal data for January-March 1998 and water levels measured in March 1998.

\section{Aquifer-System Geometry and Model Grid}

Walker and Jacobsen (2004) subdivided the hydrogeologic framework of the Potomac-Raritan-Magothy aquifer system into a detailed 11-layer framework for use in the local ground-water flow model. The most important differences between this detailed framework and the regional 5-layer framework included modifications to the representation of the confining unit between the Middle and Lower aquifers and differences in the variability of hydraulic properties in the Lower aquifer. The uppermost unit (A-1) represents the Upper aquifer of the Potomac-Raritan-Magothy aquifer system and generally corresponds to the sand of the Magothy Formation and the overlying Miocene and Pleistocene deposits. The Upper aquifer is modeled as unconfined in its outcrop area (fig. 2). Where the Upper aquifer is overlain by the MerchantvilleWoodbury confining unit, it is modeled as a confined aquifer. Because the units dip, all of the layers have both unconfined and confined areas. In MODFLOW, only the uppermost layer can be modeled as unconfined (transmissivity varies with water level); therefore, the Upper aquifer is modeled in this manner. All other layers are modeled as confined units. Where these units crop out, they are modeled, wherever possible, as unconfined units, either by specifying appropriate recharge values or applying river boundaries along with storage factors that reflect unconfined conditions (specific yield). The effect of fixed transmissivity in the outcrop areas of these other units is considered to be negligible because changes in water levels are small compared to the model layer thicknesses. 


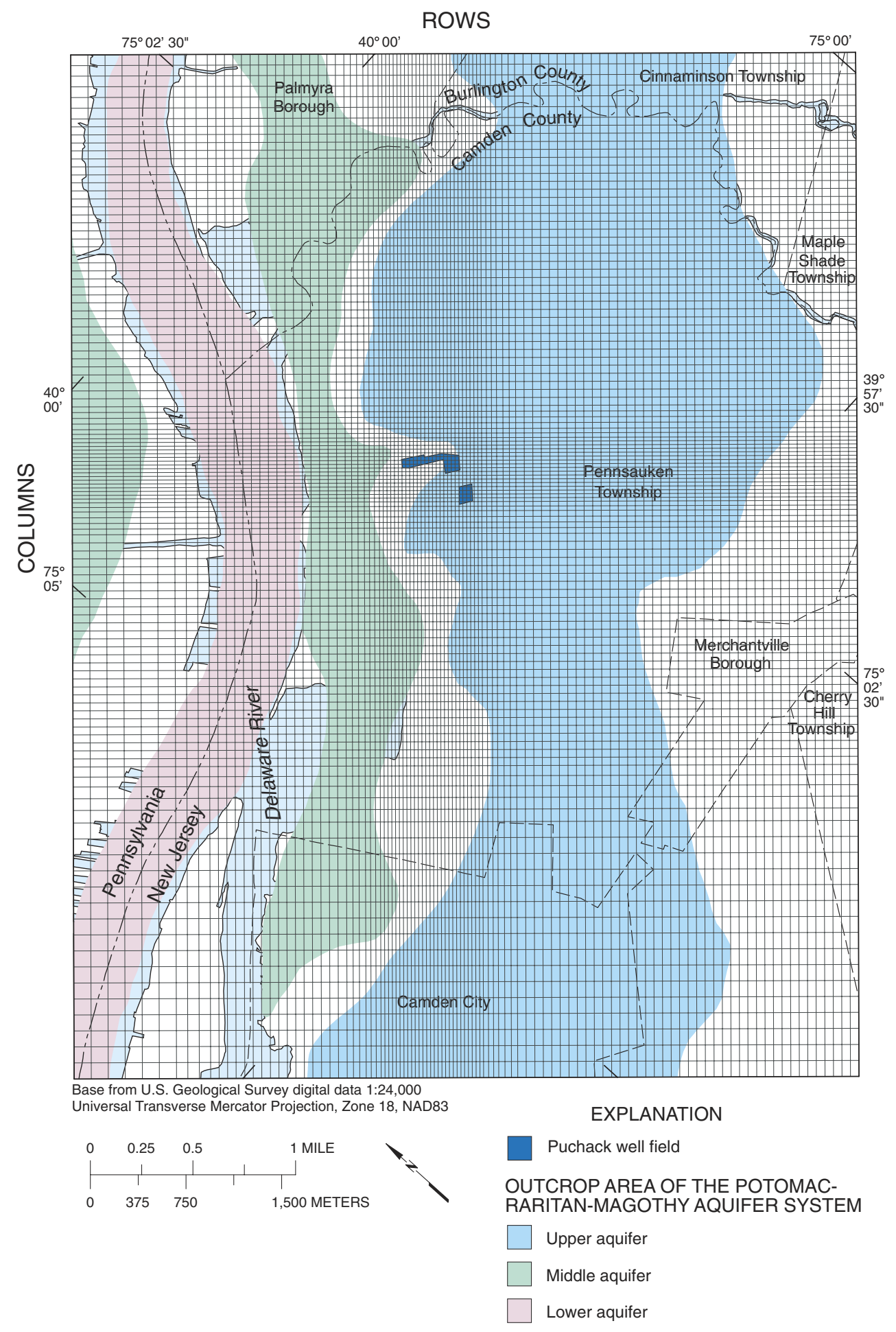

Figure 2. Ground-water flow model grid used for contributing-area delineation, and outcrop areas of the Potomac-Raritan-Magothy aquifer system, Pennsauken Township and vicinity, Camden County, New Jersey. 
The confining unit overlying the Middle aquifer is represented by a single model layer $(\mathrm{C}-1)$. The Middle aquifer is modeled as two sand units (A-2a and A-2b) and a thin intervening clay $(\mathrm{A}-2 \mathrm{c} 1)$. In most areas, the heads in units $\mathrm{A}-2 \mathrm{a}$ and $\mathrm{A}-2 \mathrm{~b}$ are similar.

The confining unit between the Middle and Lower aquifers is represented by three model layers - a low permeability layer (C-2a), a sandy unit (C-2AI) referred to in this report as the Intermediate sand, and an underlying layer that ranges from clay to sand (C-2b). Measured water levels in nested wells and data from well logs indicate that layer $\mathrm{C}-2 \mathrm{~b}$ is more permeable than layer $\mathrm{C}-2 \mathrm{a}$. In areas where the lower unit $(\mathrm{C}-2 \mathrm{~b})$ is more permeable, the Intermediate sand $(\mathrm{C}-2 \mathrm{AI})$ is in direct connection with the underlying Lower aquifer.

The Lower aquifer is represented by three sand units (A-3a, A-3b, and A-3c). The three layers allow the model to represent observed differences in conductivity, from least permeable in the uppermost part of the aquifer (near confining unit C-2b) to most permeable in the deepest part. The outcrop area of the Lower aquifer, as shown in figure 2, generally coincides with the Delaware River, and the aquifer is in direct contact with riverbed sediments. The lowest of these units, A-3c, represents a permeable gravel that is present throughout much of the model area. The base of the flow system is weathered bedrock or a clay unit overlying the bedrock (C3), which is considered to be impermeable.

The local flow model used for steady-state calibration consists of 85 rows, 108 columns, and 11 layers that represent both aquifers and confining units. Cell sizes used in the model range from 206 by $219 \mathrm{ft}$ near the Puchack well field to 412 by $440 \mathrm{ft}$ at the edge of the model area. After calibration, the model was rediscretized to comply with NJDEP guidelines for delineating contributing areas. The model grid used for contributing-area delineation, along with the outcrop areas of the major aquifers, are shown in figure 2 . The rediscretized local model has 104 rows and 121 columns but maintains the same 11 layers vertically. Cell sizes range from 97 by $98 \mathrm{ft}$ near the Puchack well field to 412 by $440 \mathrm{ft}$ at the edge of the model.

\section{Boundary Conditions}

Model-boundary conditions are recharge due to precipitation, flow to and from the Delaware River and smaller tributary streams (surface water), and specified flow at lateral boundaries. In this section, the final model-calibration parameters for the boundary conditions are described and details of their application are provided.

\section{Recharge}

The simulated outcrop areas of the aquifer and confining units receive recharge by means of the MODFLOW-96 Recharge package (Harbaugh and McDonald, 1996). Recharge is applied to the uppermost active cell at any location, except at river cells and where the Upper aquifer is confined; these areas do not receive recharge. Recharge zones and rates used in the model are shown in figure 3 . Recharge zones were created using generalized land-use categories obtained from the New Jersey Integrated Terrain Unit (ITU) GIS digital data set for 1986 (New Jersey Department of Environmental Protection, 1996). The major land-use categories used to represent variations in ground-water recharge are open land, residential, landfill, commercial-industrial, and impervious. Recharge rates were assumed to be highest in open-land areas and lowest in impervious areas. The impervious category represents areas where land adjacent to the Delaware River has been filled and built up. On the basis of field visits, these areas are assumed to be relatively impermeable.

Simulated recharge rates (shown on fig. 3) range from 0 to 14 inches per year and are consistent with rates used in other models throughout the New Jersey Coastal Plain (Navoy and Carleton, 1995; Martin, 1998).

\section{Surface Water}

The main surface-water body in the model area is the Delaware River and the largest tributary is Pennsauken Creek. Results of previous studies (Navoy and Carleton, 1995; Farlekas and others, 1976) and local aquifer tests (Ground Water Associates, Inc., 1995) indicate that the ground-water flow system in the study area is in hydraulic connection with the river and that the river contributes a large percentage of the inflow to the ground-water flow system. The Delaware River and its tributaries are tidal within the study area. Although river stage varies nearly $6 \mathrm{ft}$ with each tidal cycle, it is the average state that is important for long-term ground-water model calibration (Navoy and Carleton, 1995). In order to simulate average annual conditions, the river stage in the model was assumed to be $0.5 \mathrm{ft}$ above the NGVD of 1929 for all river cells. Riverbed sediments were assumed to be $10 \mathrm{ft}$ thick in the main stem of the Delaware River and $3 \mathrm{ft}$ thick in Pennsauken Creek. The zones of riverbed hydraulic conductivity, riverbed sediment thickness, and river stage used in this model are the same as those used by Navoy and Carleton (1995) in their model of the Camden area (fig. 4). The riverbed hydraulic conductivity zones from Navoy and Carleton (1995) were determined using surface-geophysical data collected by Duran (1986). Calibrated values of the riverbed hydraulic conductivity are shown in figure 4.

Flow in the Delaware River and Pennsauken Creek were simulated using the MODFLOW-96 River Package (Harbaugh and McDonald, 1996). The riverbed conductance (Criv) at each designated river cell (used as input to the River Package in the model) is calculated from the area of the river cell (area), the bed thickness $(M)$, and the riverbed hydraulic conductivity (Kriv):

$$
\text { Criv }=\left(\text { Kriv }^{*} \text { area }\right) / M .
$$




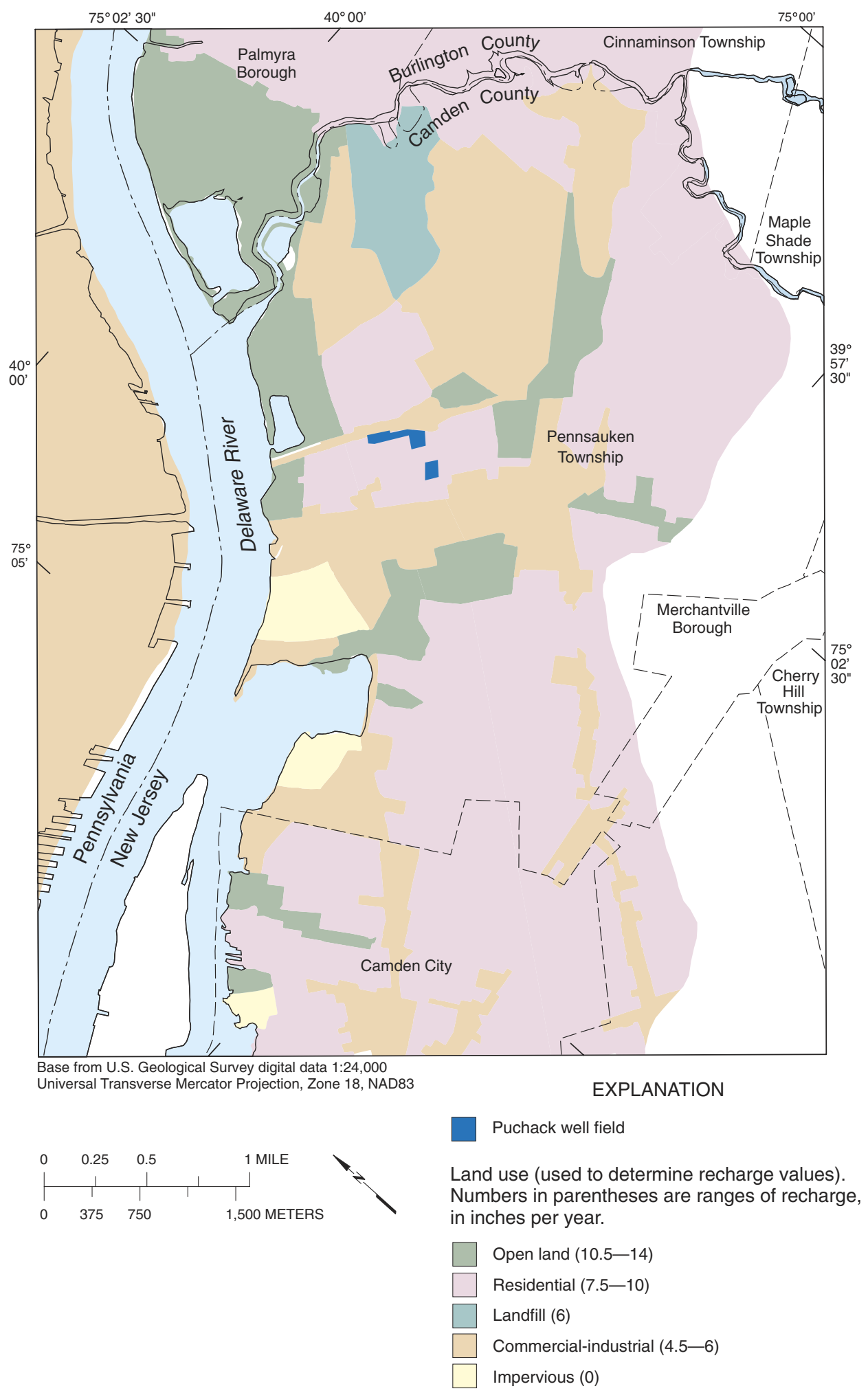

Figure 3. Recharge used in the ground-water flow model, Pennsauken Township and vicinity, Camden County, New Jersey. 


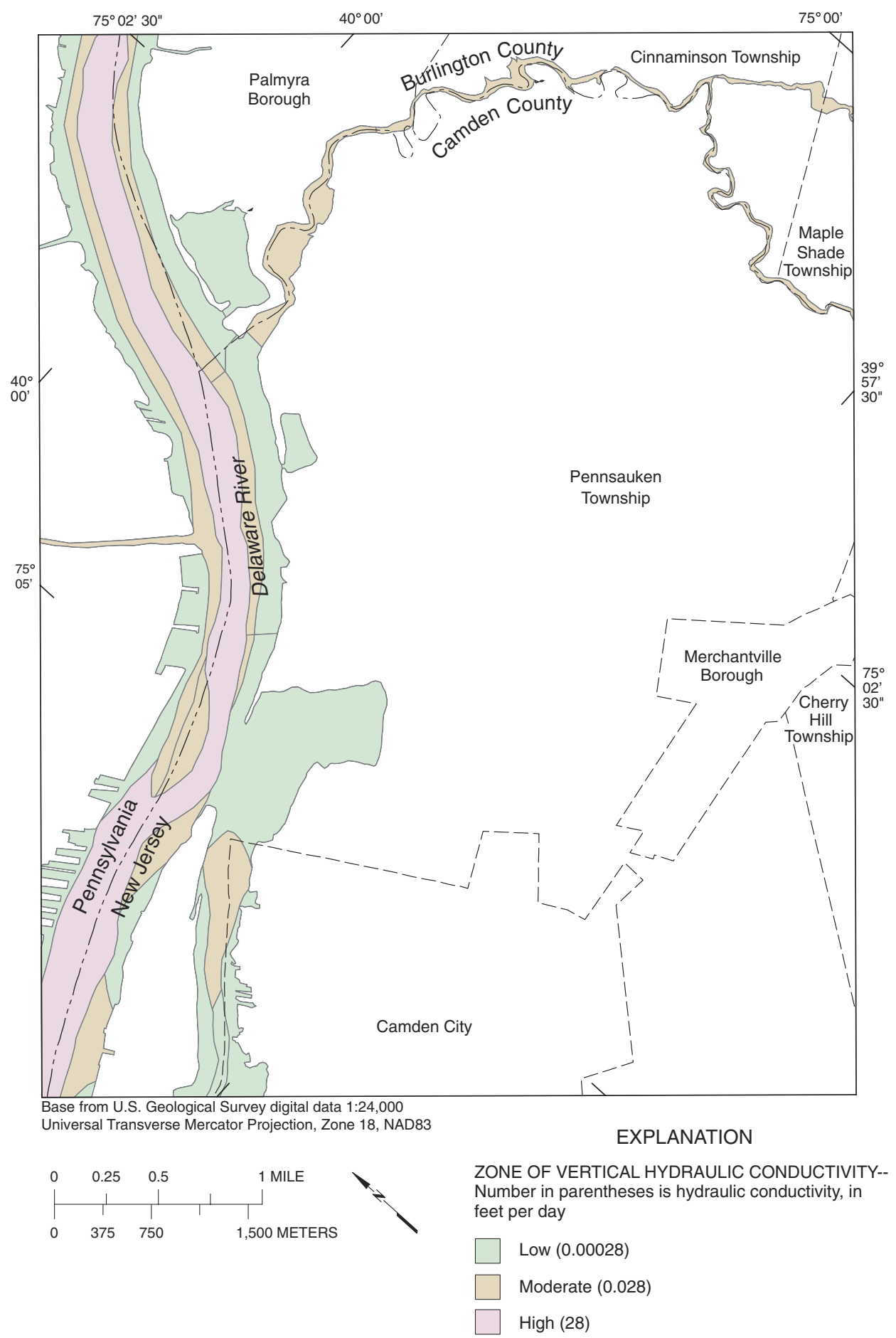

Figure 4. Hydraulic conductivity of the riverbed material, Pennsauken Township and vicinity, Camden County, New Jersey. 


\section{Lateral Model Boundaries}

The Potomac-Raritan-Magothy aquifer system is used heavily for ground-water supplies in the area. Explicit simulation of effects of these regional ground-water withdrawals would require a larger model area that includes hydrologic boundaries and withdrawal centers. This approach was impractical because of the level of detail needed in the local model area. Therefore, a regional-scale, model of the Potomac-Raritan-Magothy aquifer system in Camden County and parts of Burlington and Gloucester Counties (Navoy and Carleton, 1995) was used to provide steady-state boundary fluxes to the local model. This approach allowed the regional effects that occur outside the model area to be included in the local model.

Boundary flows were assigned to local model layers representing the Upper aquifer (A-1), the Middle aquifer (A-2a and A-2b), and the Lower aquifer (A-3a, A-3b, and A-3c) using the Flow and Head Boundary (FHB) package (Leake and Lilly, 1997). Flows were not assigned to confining-unit layers because the regional model used a quasi-threedimensional approach in which the flow in the confining units was not simulated. Boundary flows from the Upper aquifer in the regional model were assigned to unit A-1. In the Upper aquifer, the fluxes along both the lateral and downgradient edges of the local model were important because flow volumes were large perpendicular to the local model boundaries near Pennsauken Creek to the north and the Cooper River to the south. Boundary flows from the Middle aquifer in the regional model were divided equally between local-model units A-2a and A-2b. Boundary flows from the Lower aquifer in the regional model were divided equally among local-model units A-3a, A-3b, and A-3c.

\section{Ground-Water Withdrawal Data}

Monthly withdrawal data for public-supply wells in the local model area in 1998 were obtained from NJDEP Bureau of Water Allocation files. In some cases, however, only one value was reported for a well field because its wells were not metered individually at the time of data collection. To estimate withdrawals for individual wells, the reported withdrawal value for a well field was divided by the number of wells in that well field that were active at the time. Reported pump capacities at certain wells also were used to disaggregate the monthly data.

In many cases, the screens of the public-supply wells cross more than one model layer. Therefore, the percentage of the well screen in each model layer was estimated and multiplied by the total withdrawal for the well to calculate the withdrawal for that model layer. This approach was considered to be reasonable because horizontal hydraulic conductivities were similar for model layers within the major (Middle and Lower) aquifers.

The distribution of ground-water withdrawals from public-supply wells in the model area is shown in figure 5. Aver- age withdrawals for January-March 1998 that were used in the model calibration are shown in figure 5 and table 3.

\section{Hydrogeologic Properties}

Available hydraulic-conductivity data from aquifer tests, well acceptance tests, and results of previous simulations were used to assign initial values in the model. Hydraulic conductivities of aquifers and confining units were adjusted during model calibration in order to obtain a good fit to the observed flow system. The calibrated values of horizontal hydraulic conductivity for the aquifers and vertical hydraulic conductivity for the confining units are described in the following sections.

\section{Horizontal Hydraulic Conductivity of Aquifers and Confining Units}

Calibrated values of horizontal hydraulic conductivity in the Potomac-Raritan-Magothy aquifer system used in the model ranged from 50 to $250 \mathrm{ft} / \mathrm{d}$. The vertical hydraulic conductivity of the aquifer units was assumed to be one-tenth the horizontal hydraulic conductivity to account for bedding planes and laminations within the sediments (Anderson and Woessner, 1991).

The horizontal hydraulic conductivity of the Upper aquifer (A1) was simulated as a uniform value of $50 \mathrm{ft} / \mathrm{d}$. The horizontal hydraulic conductivity of the Middle aquifer (A-2a and A-2b) used in the model was $60 \mathrm{ft} / \mathrm{d}$. The Intermediate sand (C-2AI) was simulated using a hydraulic conductivity of $100 \mathrm{ft} / \mathrm{d}$. The horizontal hydraulic conductivity of the confining layer within the Middle aquifer $(\mathrm{A}-2 \mathrm{c} 1)$ is $4 \mathrm{ft} / \mathrm{d}$. The horizontal hydraulic conductivity was assumed to be 10 times the vertical hydraulic conductivity for all other confining-unit layers.

All the layers in the Lower aquifer consist of permeable sands with relatively high hydraulic conductivity (130$250 \mathrm{ft} / \mathrm{d}$ ). The two upper layers (A3-a and A3-b) are composed of coarse sands. The lowermost layer in the Lower aquifer (A-3c) represents very coarse and highly conductive sands and gravels. The extent of layer A3-c and the zones of hydraulic conductivity within it (determined from well logs) are shown in figure 6 . Horizontal hydraulic-conductivity values estimated from specific-capacity data from public-supply wells are shown in figure 6 and table 4. Estimates were made for wells with a specific-capacity test with a pumping rate of at least $500 \mathrm{gal} / \mathrm{min}$ for a minimum of 8 hours. The transmissivity of the aquifer in the vicinity of these wells was estimated from specific-capacity data using the Theis equation (Heath, 1983). The horizontal hydraulic conductivity of layers A-3a, A-3b, and the portion of $\mathrm{A}-3 \mathrm{c}$ where the gravel unit is not present is $130 \mathrm{ft} / \mathrm{d}$. The conductivity of the permeable sand and gravel portions of A3-c is $250 \mathrm{ft} / \mathrm{d}$. The conductivity values used in the model generally are lower than those estimated from specific-capacity data. 


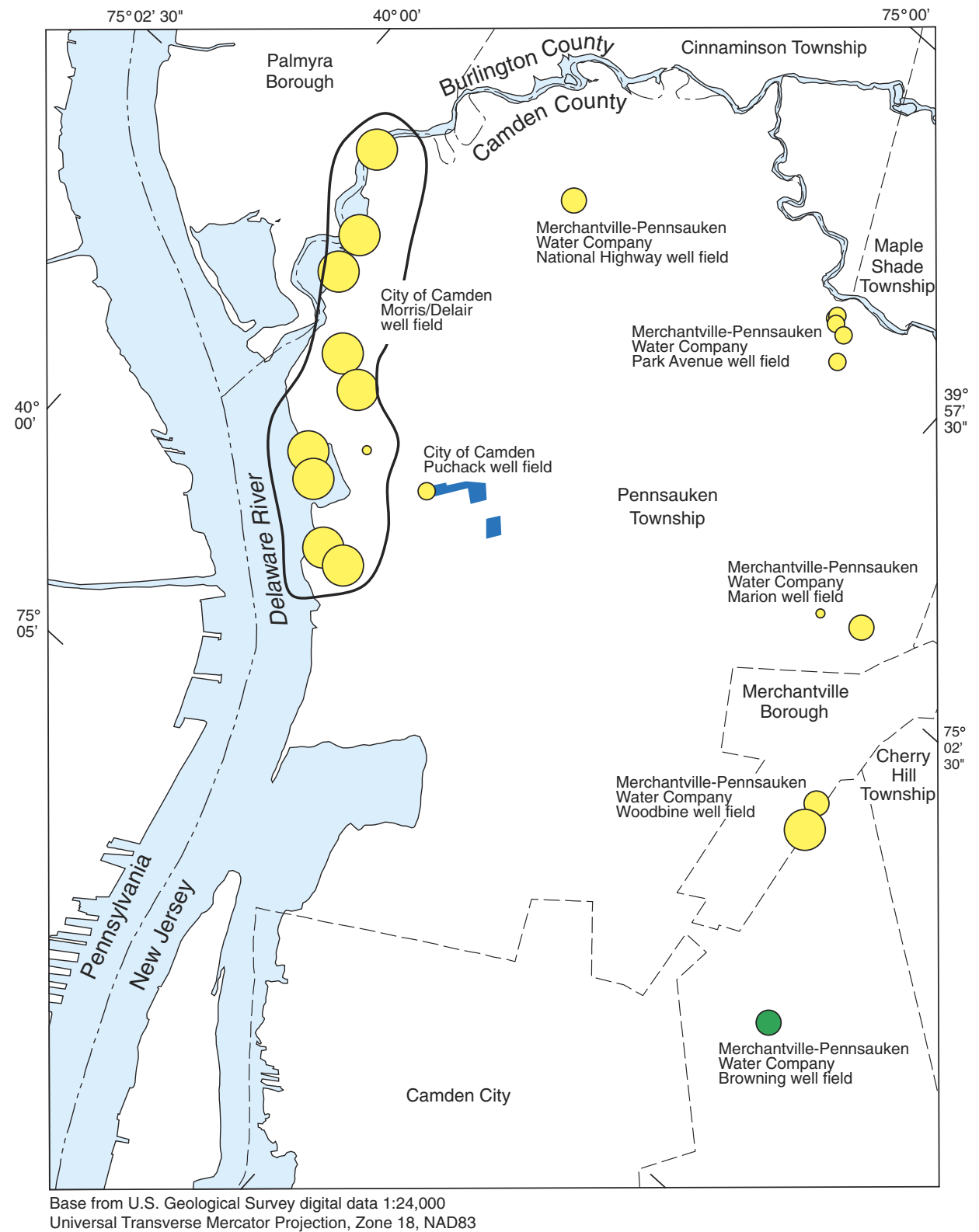

ection, Zone 18, NAD8

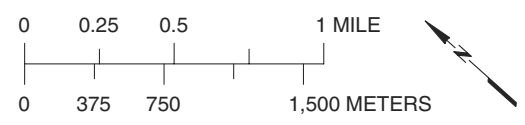

EXPLANATION

Puchack well field

GROUND-WATER WITHDRAWALS--From the Middle aquifer of the Potomac-Raritan-Magothy aquifer system, January-March 1998, in million gallons per month

Greater than 50 to 75

GROUND-WATER WITHDRAWALS--From the Lower aquifer of the Potomac-Raritan-Magothy aquifer system, January-March 1998, in million gallons per month
○ Less than 20
Greater than 50 to 75
Greater than 20 to 50
Greater than 75

Figure 5. Average ground-water withdrawals during January-March 1998 in the steady-state flow model, Pennsauken Township and vicinity, Camden County, New Jersey. 
Table 3. Ground-water withdrawal data used in the ground-water flow model, Pennsauken Township and vicinity, Camden County, New Jersey.

[NJDEP, New Jersey Department of Environmental Protection; calibration withdrawals are average water use during January-March 1998; delineation withdrawals are 1998 withdrawals for all wells except Puchack wells; withdrawals for each Puchack well is 1 million gallons per day]

\begin{tabular}{|c|c|c|c|c|}
\hline \multirow{2}{*}{$\begin{array}{c}\text { U.S. } \\
\text { Geological } \\
\text { Survey well } \\
\text { number }\end{array}$} & \multirow{2}{*}{$\begin{array}{c}\text { NJDEP } \\
\text { well } \\
\text { permit } \\
\text { number }\end{array}$} & \multirow{2}{*}{ Well name } & \multicolumn{2}{|c|}{$\begin{array}{c}\text { Withdrawals, } \\
\text { in million gallons }\end{array}$} \\
\hline & & & $\begin{array}{l}\text { Calibration } \\
\text { (3 months) }\end{array}$ & $\begin{array}{c}\text { Delineation } \\
\text { (1 year) }\end{array}$ \\
\hline \multicolumn{5}{|c|}{ City of Camden } \\
\hline $7-368$ & $51-00053$ & DELAIR 1 & 86.80 & 288.1 \\
\hline $7-369$ & 51-00054 & DELAIR 2 & 0 & 288.1 \\
\hline $7-370$ & 51-00055 & DELAIR 3 & 86.80 & 288.1 \\
\hline $7-390$ & $51-00050$ & MORRIS 1 & 89.90 & 288.1 \\
\hline $7-386$ & $31-00945$ & MORRIS 3 & 89.90 & 288.1 \\
\hline $7-382$ & $31-04252$ & MORRIS 4 & 89.90 & 288.1 \\
\hline $7-373$ & $51-00051$ & MORRIS 6 & 19.40 & 79.0 \\
\hline $7-375$ & 31-00944 & MORRIS 8 & 78.0 & 288.1 \\
\hline $7-379$ & $31-04251$ & MORRIS 10 & 89.90 & 288.1 \\
\hline $7-545$ & $31-15745$ & MORRIS 11 & 0 & 288.1 \\
\hline $7-586$ & $31-16814$ & MORRIS 12 & 89.90 & 288.1 \\
\hline $7-587$ & $31-16813$ & MORRIS 13 & 89.90 & 288.1 \\
\hline $7-1070$ & $31-56691$ & MORRIS 14 & 0 & 288.1 \\
\hline $7-1071$ & $31-57430$ & MORRIS 15 & 0 & 288.1 \\
\hline $7-366$ & $51-00056$ & PUCHACK 1 & 67.0 & 365.0 \\
\hline $7-363$ & $51-00057$ & PUCHACK 2 & 0 & 365.0 \\
\hline $7-367$ & $51-00058$ & PUCHACK 3 & 0 & 365.0 \\
\hline $7-358$ & $31-05450$ & PUCHACK 6 & 0 & 365.0 \\
\hline $7-359$ & 51-00059 & PUCHACK 5 & 0 & 365.0 \\
\hline $7-528$ & $31-08526$ & PUCHACK 7 & 0 & 365.0 \\
\hline \multicolumn{5}{|c|}{ Merchantville-Pennsauken Water Company } \\
\hline $7-319$ & $31-05641$ & BROWNING 1 & 62.08 & 258.0 \\
\hline $7-335$ & $31-02915$ & MARION 1 & 2.65 & 126.8 \\
\hline $7-332$ & $31-04641$ & MARION 2 & 62.30 & 311.0 \\
\hline $7-602$ & $31-19207$ & NATIONAL HWY 2 & 69.40 & 260.0 \\
\hline $7-349$ & $31-00010$ & PARK AVE 1 & 41.76 & 156.2 \\
\hline $7-350$ & $51-00064$ & PARK AVE 2 & 41.76 & 156.2 \\
\hline $7-348$ & $31-03534$ & PARK AVE 3 & 41.76 & 156.2 \\
\hline $7-345$ & $31-00011$ & PARK AVE 5 & 41.76 & 156.2 \\
\hline $7-530$ & $31-14564$ & 4R-A/PARK AVE 6 & 41.76 & 156.2 \\
\hline $7-320$ & $31-04642$ & WOODBINE 1 & 50.60 & 169.8 \\
\hline $7-560$ & $31-14563$ & WOODBINE 2 & 103.26 & 347.6 \\
\hline
\end{tabular}




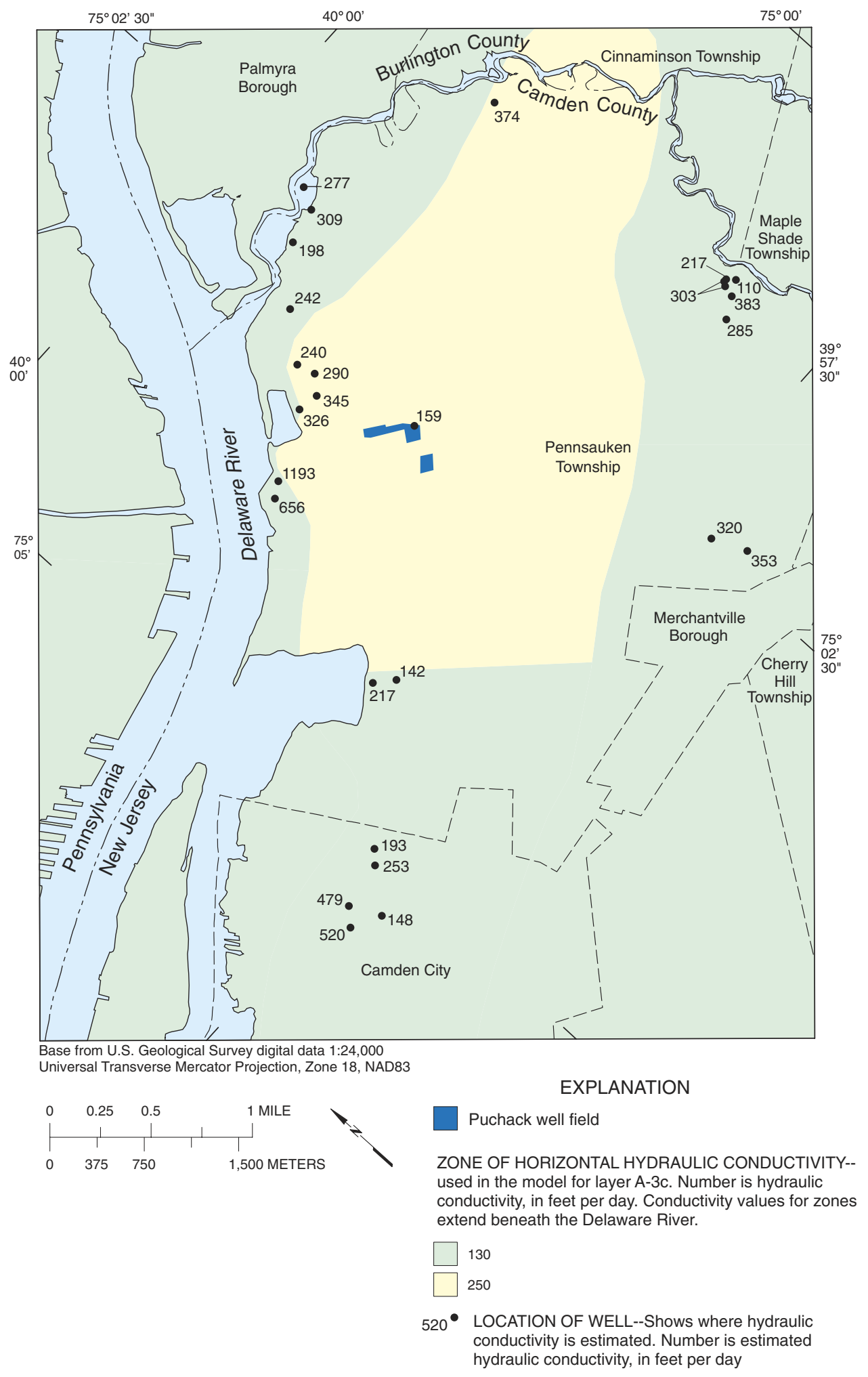

Figure 6. Horizontal hydraulic conductivity of the Lower aquifer of the Potomac-RaritanMagothy aquifer system in the ground-water flow model, Pennsauken Township and vicinity, Camden County, New Jersey. 
Table 4. Wells with aquifer-test data and estimates of hydraulic conductivity, Pennsauken Township and vicinity, Camden County, New Jersey.

[*, well has multiple screened intervals; --, data not available]

\begin{tabular}{|c|c|c|c|c|c|c|}
\hline $\begin{array}{l}\text { U.S. Geological } \\
\text { Survey well } \\
\text { number }\end{array}$ & Well name & $\begin{array}{l}\text { Depth of well } \\
\text { (feet below land } \\
\text { surface) }\end{array}$ & $\begin{array}{l}\text { Well diameter } \\
\text { (inches) }\end{array}$ & $\begin{array}{l}\text { Estimated } \\
\text { hydraulic } \\
\text { conductivity } \\
\text { (feet per day) }\end{array}$ & $\begin{array}{l}\text { Length of test } \\
\text { (hours) }\end{array}$ & $\begin{array}{c}\text { Discharge } \\
\text { during test } \\
\text { (gallons per } \\
\text { minute) }\end{array}$ \\
\hline $7-109$ & CAMDEN DIV 46 & 178 & 12 & 520 & 8 & 1,400 \\
\hline $7-111$ & CAMDEN DIV 50 & 170 & 12 & 479 & 8 & 1,000 \\
\hline $7-325$ & BROWNING RD 2 & 240 & -- & 293 & -- & -- \\
\hline $7-332$ & MARION 2 & 258 & 12 & 353 & 8 & 1,000 \\
\hline $7-335$ & MARION 1 & 278 & 12 & 320 & 8 & 1,020 \\
\hline $7-341$ & DELA GARDEN 2 & 145 & 12 & 217 & 8 & 728 \\
\hline $7-342$ & DELA GARDEN 1A & 139 & 12 & 142 & 8 & 882 \\
\hline $7-344$ & PARK AVE REP 4 & 178 & 8 & 360 & 12 & 530 \\
\hline $7-345$ & PARK AVE 5 & 288 & 12 & 383 & 8 & 1,010 \\
\hline $7-346$ & PARK AVE 3A & 260 & 11 & 110 & 24 & 720 \\
\hline $7-347$ & PARK AVE 4 & 181 & 10 & 306 & 12 & 600 \\
\hline $7-348$ & MPWC PARK AVE 3 & 275 & 12 & 303 & 8 & 1,030 \\
\hline $7-349$ & PARK AVE 1 & 270 & 12 & 217 & 8 & 1,010 \\
\hline $7-350$ & PARK AVE 2 & 257 & 12 & 303 & 8 & 1,000 \\
\hline $7-369$ & DELAIR 2 & 146 & 26 & $656 *$ & 8 & 1,330 \\
\hline $7-370$ & DELAIR 3 & 132 & 26 & $1,193 *$ & 8 & 1,850 \\
\hline $7-373$ & MORRIS 6 & 138 & 26 & 345 & 8 & 1,700 \\
\hline $7-374$ & MORRIS 9/9N & 143 & 26 & $290 *$ & 8 & 1,900 \\
\hline $7-377$ & MORRIS 7 & 120 & 26 & 240 & 8 & 1,680 \\
\hline $7-379$ & MORRIS 10 & 118 & 18 & 242 & 8 & 1,450 \\
\hline $7-382$ & MORRIS 4A & 134 & 18 & 198 & 8 & 1,590 \\
\hline $7-386$ & MORRIS 3A & 107 & 18 & 309 & 8 & 1,000 \\
\hline $7-388$ & MORRIS 5 & 115 & 26 & 277 & 8 & 1,630 \\
\hline $7-528$ & PUCHACK 7 & 180 & 18 & 159 & 8 & 1,290 \\
\hline $7-530$ & 4R-A/PARK AVE 6 & 270 & 36 & 285 & 8 & 1,520 \\
\hline $7-545$ & MORRIS 11 & 149 & 16 & 326 & 24 & 2,030 \\
\hline $7-547$ & 54 & 200 & 16 & 193 & 24 & 1,210 \\
\hline $7-597$ & 55 & 176 & -- & 148 & -- & -- \\
\hline $7-602$ & NATIONAL HWY 2 & 206 & 12 & 374 & 8 & 1,240 \\
\hline $7-724$ & CLEVELAND AVE PW 53 & 194 & 16 & 253 & 24 & 1,210 \\
\hline
\end{tabular}




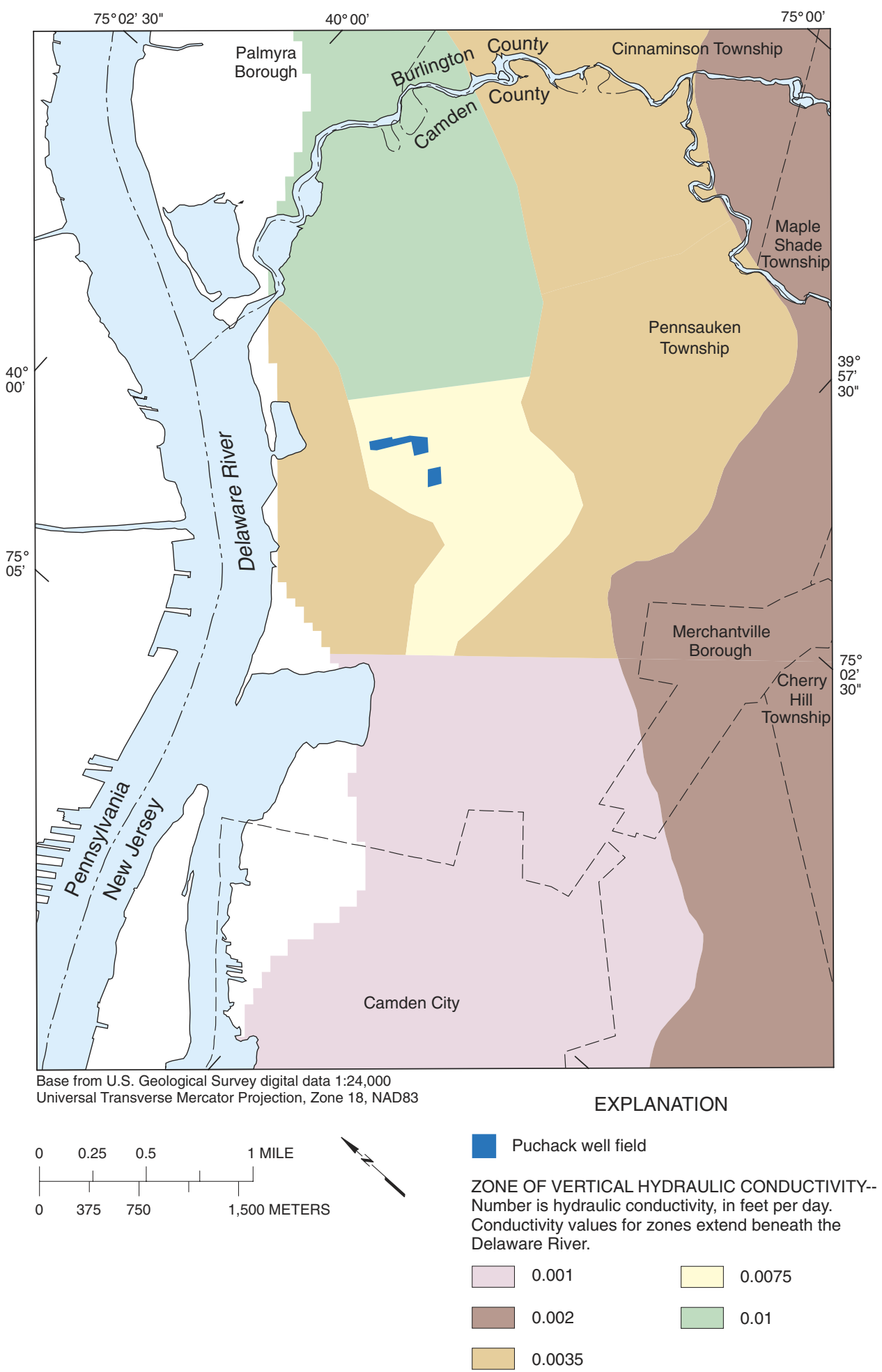

Figure 7. Vertical hydraulic conductivity in confining unit C-1 (between the Upper and Middle aquifers of the Potomac-Raritan-Magothy aquifer system) in the ground-water flow model, Pennsauken Township and vicinity, Camden County, New Jersey. 


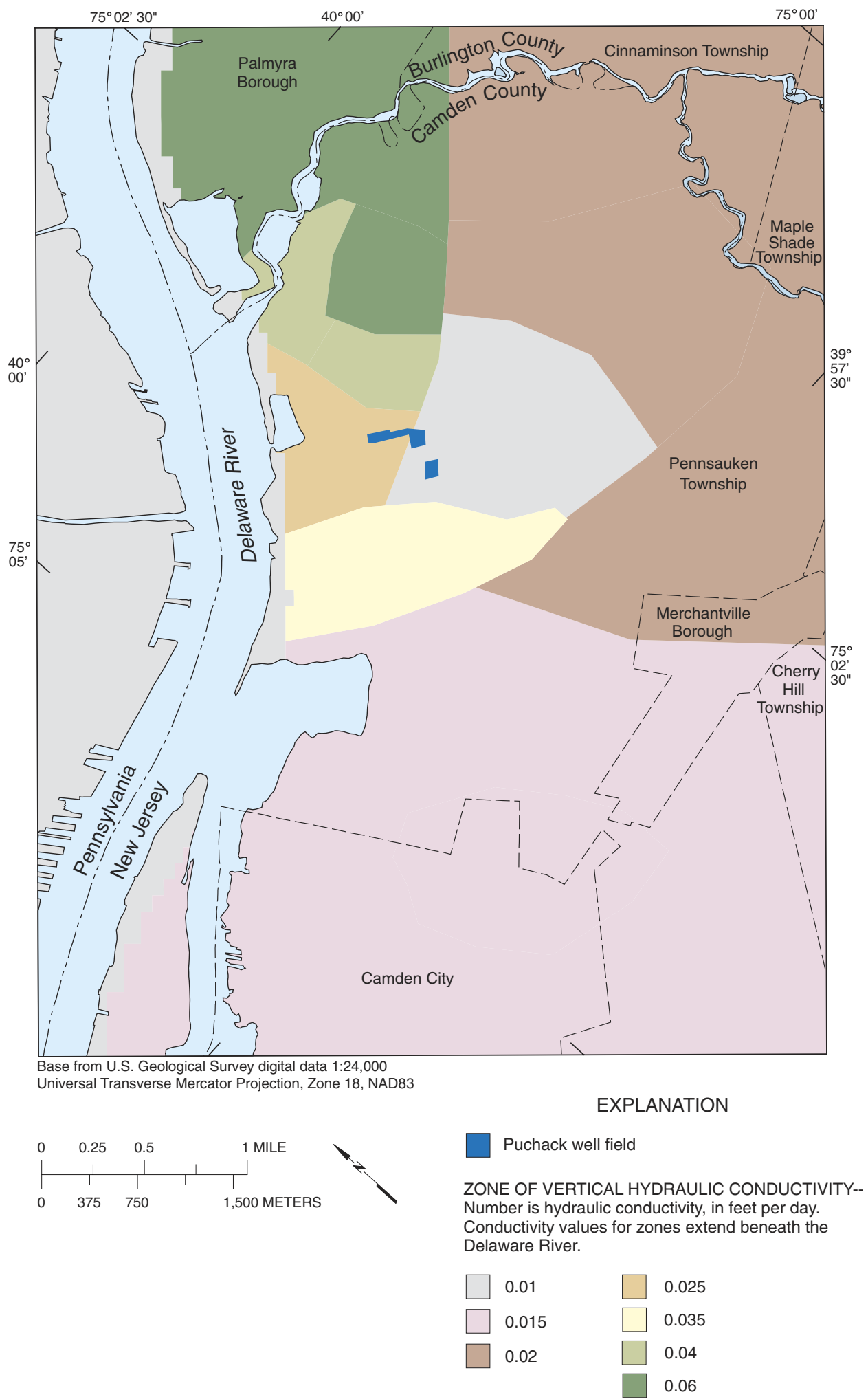

Figure 8. Vertical hydraulic conductivity in confining unit C-2a (between the Middle aquifer of the Potomac-Raritan-Magothy aquifer system and the Intermediate sand) in the ground-water flow model, Pennsauken Township and vicinity, Camden County, New Jersey. 


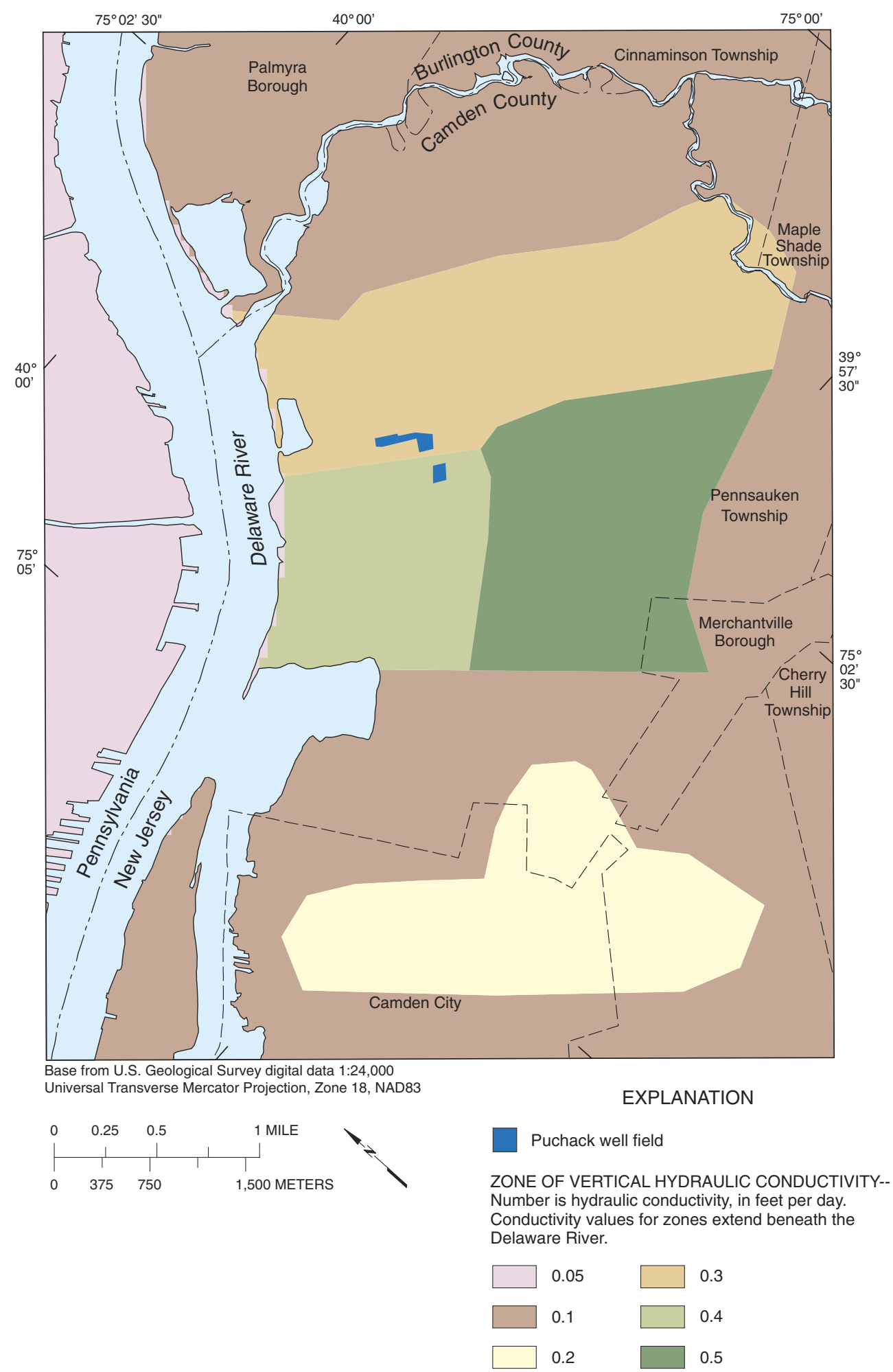

Figure 9. Vertical hydraulic conductivity in confining unit C-2b (between the Intermediate sand and the Lower aquifer of the Potomac-Raritan-Magothy aquifer system) in the ground-water flow model, Pennsauken Township and vicinity, Camden County, New Jersey. 
Water levels measured in March 1998 were compared to average January-March simulated heads. The calibration criterion was that the simulated heads be within $\pm 5 \mathrm{ft}$ of the measured heads. Water-level differences across confining units were used to help calibrate confining-unit vertical hydraulic conductivities. Where multiple wells were screened in different units (nested wells), the simulated and observed vertical differences in water levels were calculated. The calibration criterion was that the water-level differences be within $\pm 1 \mathrm{ft}$ of each other. Well nests that were used to determine vertical hydraulic conductivity are shown in figure 10 .

\section{Simulation of January-March 1998 Conditions}

The model-calibration target was the set of water levels measured in March 1998. Average withdrawal data for January-March 1998 are shown in table 3 and figure 5. Only one well in the Puchack well field -Puchack 1-was pumping; the average withdrawal for that well during January-March 1998 was $0.74 \mathrm{Mgal} / \mathrm{d}$.

The water levels in the Upper aquifer were not calibrated because few measurements of water levels in the unconfined parts of the Upper aquifer were available. The Upper aquifer was included in the model primarily to provide a pathway for vertical flow to reach the Middle aquifer and to serve as a boundary condition for the Middle aquifer. In much of the model area, the sands that make up the Upper aquifer are unsaturated as a result of pumping from the Lower aquifer.

The simulated and observed potentiometric surfaces in the Middle and Lower aquifers for January-March 1998 are shown in figures 11 and 12, respectively. Near the Puchack well field, the simulated heads at the wells generally are within $1 \mathrm{ft}$ of the measured heads in both aquifers. In the Middle aquifer, residuals generally are larger and more variable in the area north of the well field than near it (fig. 11). In the Lower aquifer (fig. 12), residuals are larger in areas distant from the well field than near it. The few wells for which residuals exceed the 5 - $\mathrm{ft}$ criterion are at or near withdrawal centers. In addition, measured water levels could be affected by as much as \pm 5 to $10 \mathrm{ft}$ at wells for which surveyed land-surface altitudes were not available and, therefore, where altitudes were estimated from contour maps. Differences between the simulated and observed gradient across confining units are shown in figure 13; the observed and simulated water-level measurements are listed in table 5. Most of the residuals were in the range of $\pm 0.5 \mathrm{ft}$, although a few were larger. The residual at MW-3 was larger than $1 \mathrm{ft}$, possibly because the measurements span both confining-unit layers $\mathrm{C}-2 \mathrm{a}$ and $\mathrm{C}-2 \mathrm{~b}$.

\section{Contributing-Area Delineation}

As discussed previously, contributing-area delineations are required for all public community water-supply (CWS) and non-community water-supply (NCWS) wells in New Jersey. Contributing areas for all wells were delineated by the
NJDEP in accordance with delineation guidelines. For CWS wells, contributing areas were delineated by combining a Calculated Fixed Radius (CFR) analysis with a two-dimensional flow model. Post-processing programs rotate the contributing areas 20 degrees clockwise and counter-clockwise, using the well as a pivot point, to account for variability in the accuracy of the estimated hydraulic gradient. The NJDEP guidelines also allow the use of a three-dimensional flow model where hydrologic conditions are complex, such as in the vicinity of the Puchack well field in Pennsauken Township, New Jersey. The contributing area to this well field was delineated by using the local ground-water flow model.

Delineation of contributing areas for the Puchack well field using a CFR analysis together with a two-dimensional flow model is difficult because

(1) well-field interference from surrounding well fields (especially the Morris/Delair well field (fig. 1)) affects the contributing area to the Puchack well field,

(2) the Puchack well field consists of multiple supply wells pumped in proximity to each other,

(3) the ground-water flow system is hydraulically connected to the Delaware River. More than 90 per cent of the flow to wells adjacent to the river (Morris/ Delair well field) is estimated to be derived from the river. More than 80 percent of the flow to the Puchack well field is estimated to be derived from the river, and

(4) although the Lower aquifer is confined in the area, downward vertical flow is substantial because withdrawals from the Lower aquifer are large.

Contributing areas for the community water-supply wells in New Jersey were subdivided into three tiers corresponding to the ranges of travel time to the well specified by NJDEP:

Tier $1 \quad 0$ to 2 years

Tier 2 greater than 2 years to 5 years

Tier 3 greater than 5 years to 12 years

In order to determine the effects of variations in model parameters on the size and shape of the contributing area, each parameter was varied (as explained in the "Uncertainty Analysis" section) and a contributing area was determined for each simulation. The contributing area delineated using the calibrated model parameters is designated as the "delineation" contributing area. After contributing areas were delineated for each variation in model data, all of the data for the 37 contributing-area delineations were analyzed together. This process resulted in a map showing the number of simulations in which each model cell contributed water to the Puchack well field within the 12-year travel time to show the uncertainty in the contributing-area delineation. An aggregate contributing area that encompasses all areas that contributed flow to the Puchack well field within the 12-year time frame also was produced. Tiers were assigned by using the minimum travel time for each area. 


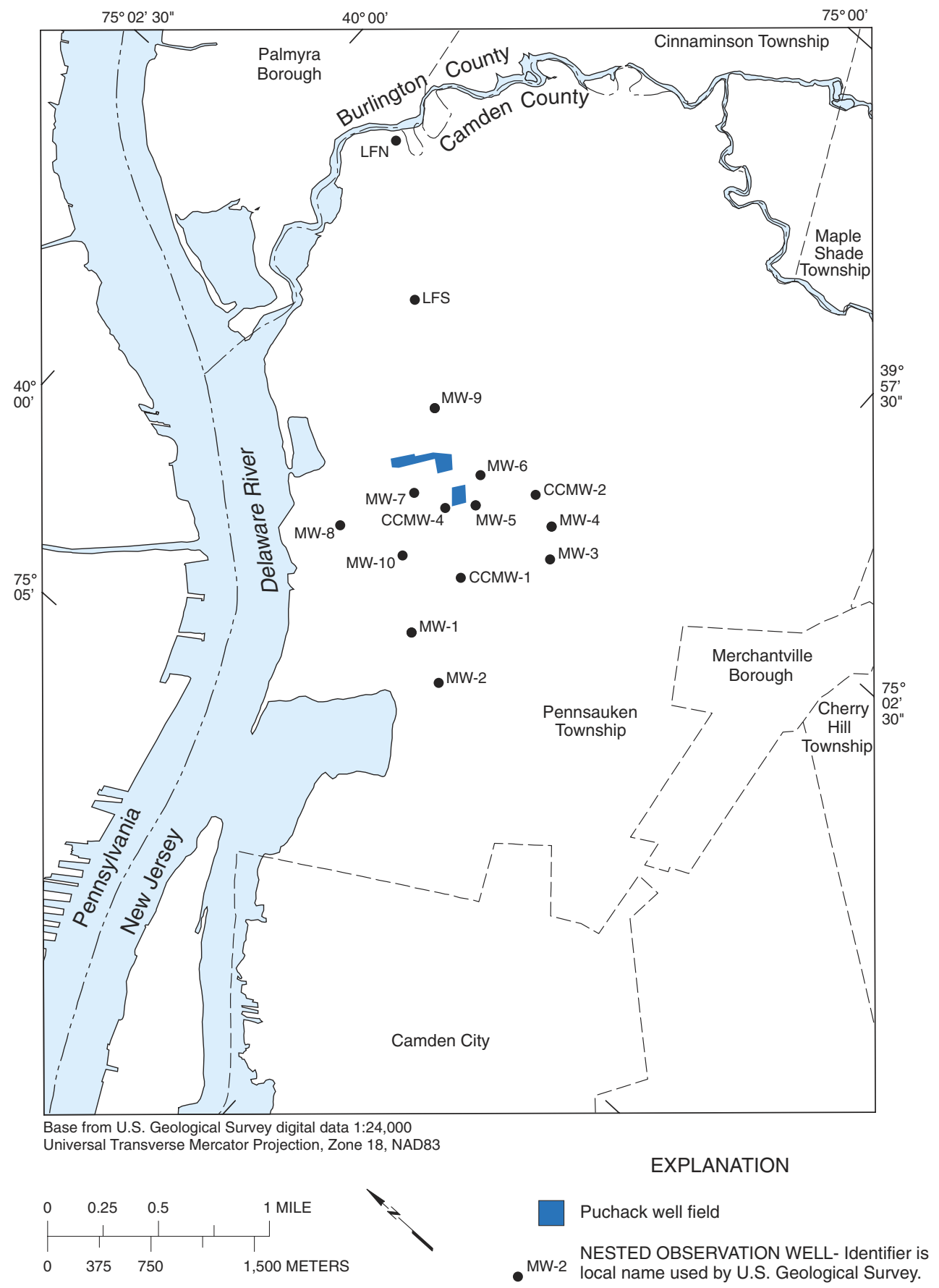

Figure 10. Location of wells used to calibrate vertical hydraulic conductivity in the groundwater flow model, Pennsauken Township and vicinity, Camden County, New Jersey. 


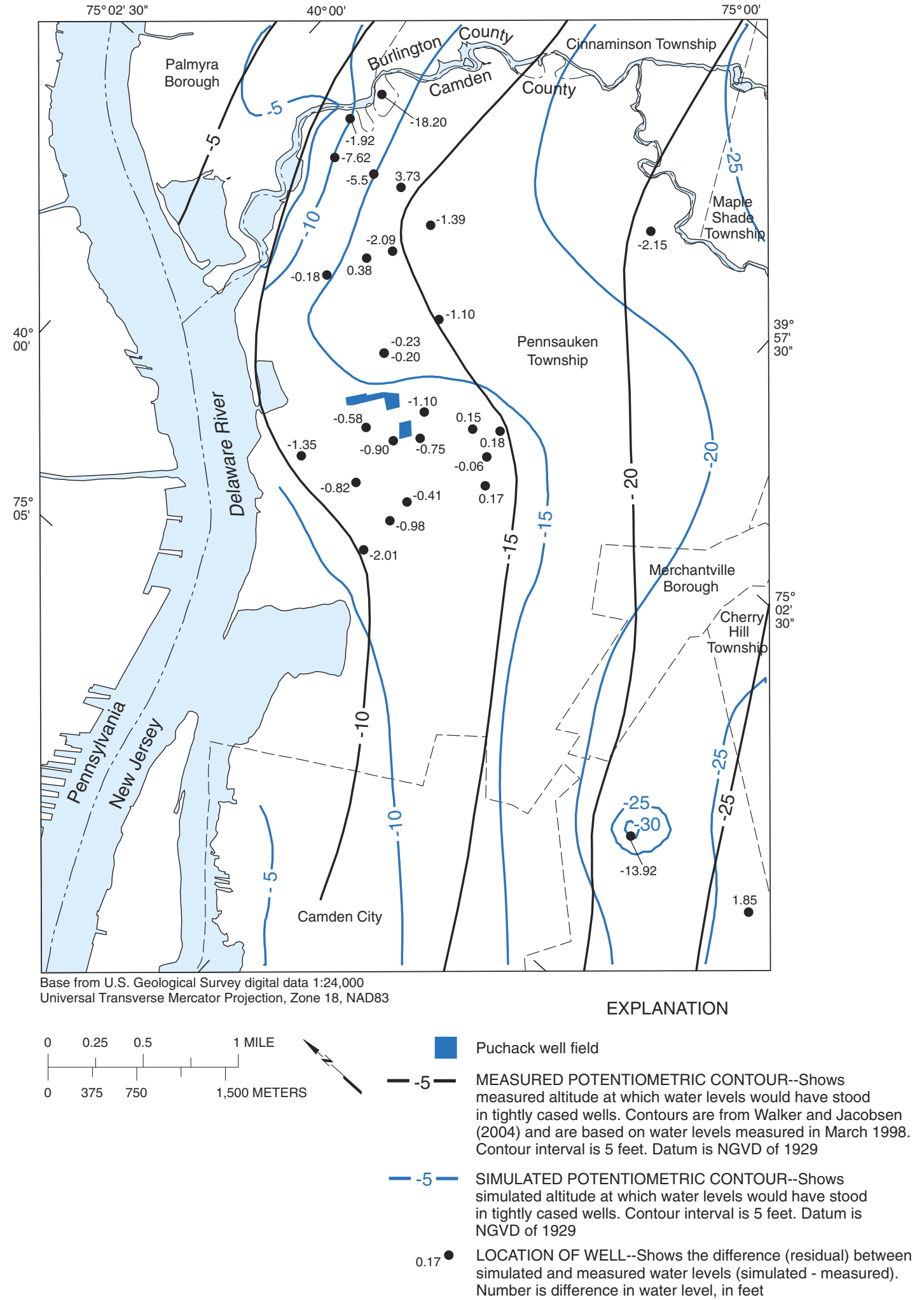

Figure 11. Simulated and measured potentiometric surfaces and residuals in the Middle aquifer of the Potomac-Raritan-Magothy aquifer system, Pennsauken Township and vicinity, Camden County, New Jersey, January-March 1998. 


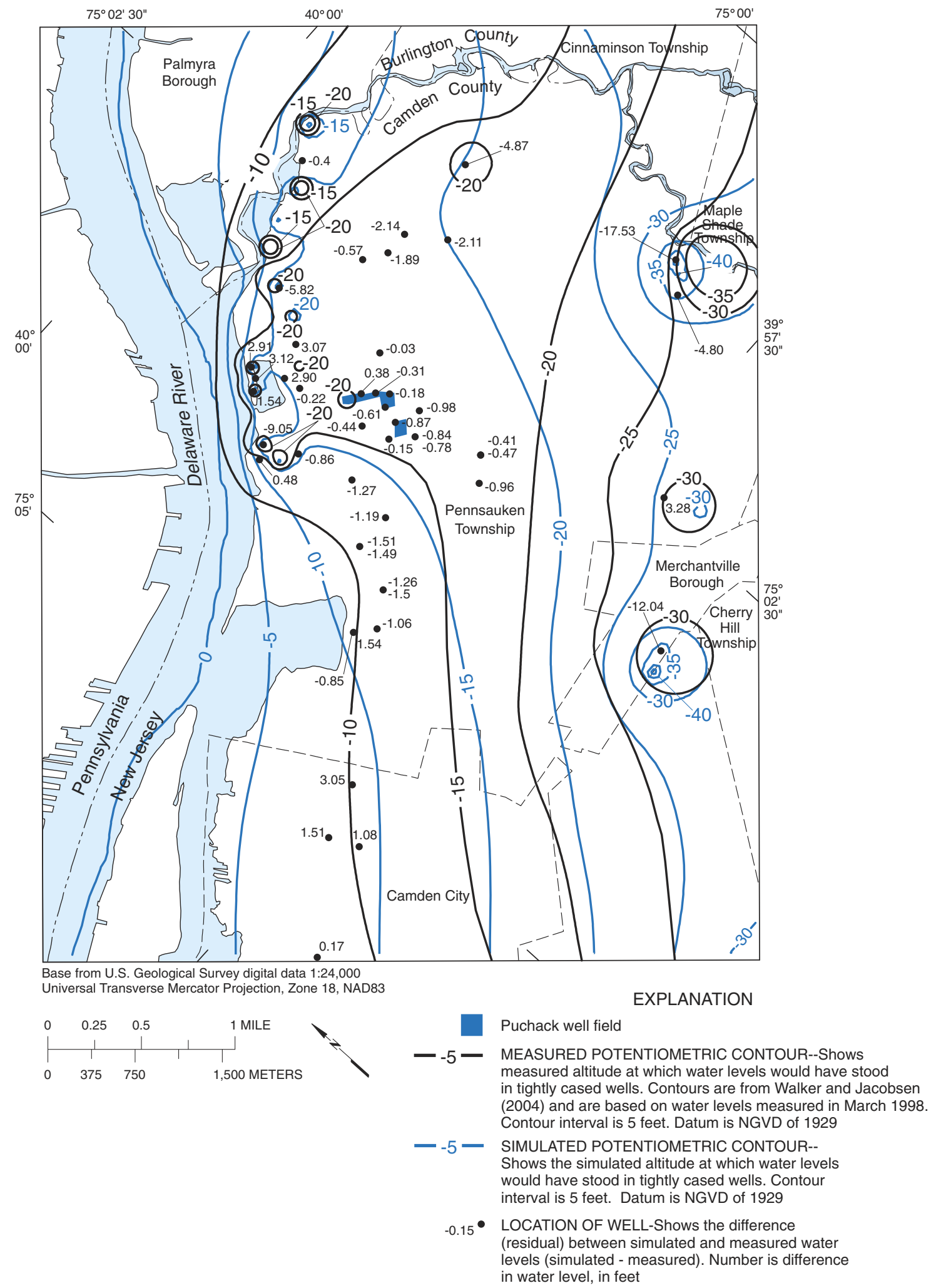

Figure 12. Simulated and measured potentiometric surfaces and residuals in the Lower aquifer of the Potomac-Raritan-Magothy aquifer system, Pennsauken Township and vicinity, Camden County, New Jersey, January-March 1998. 

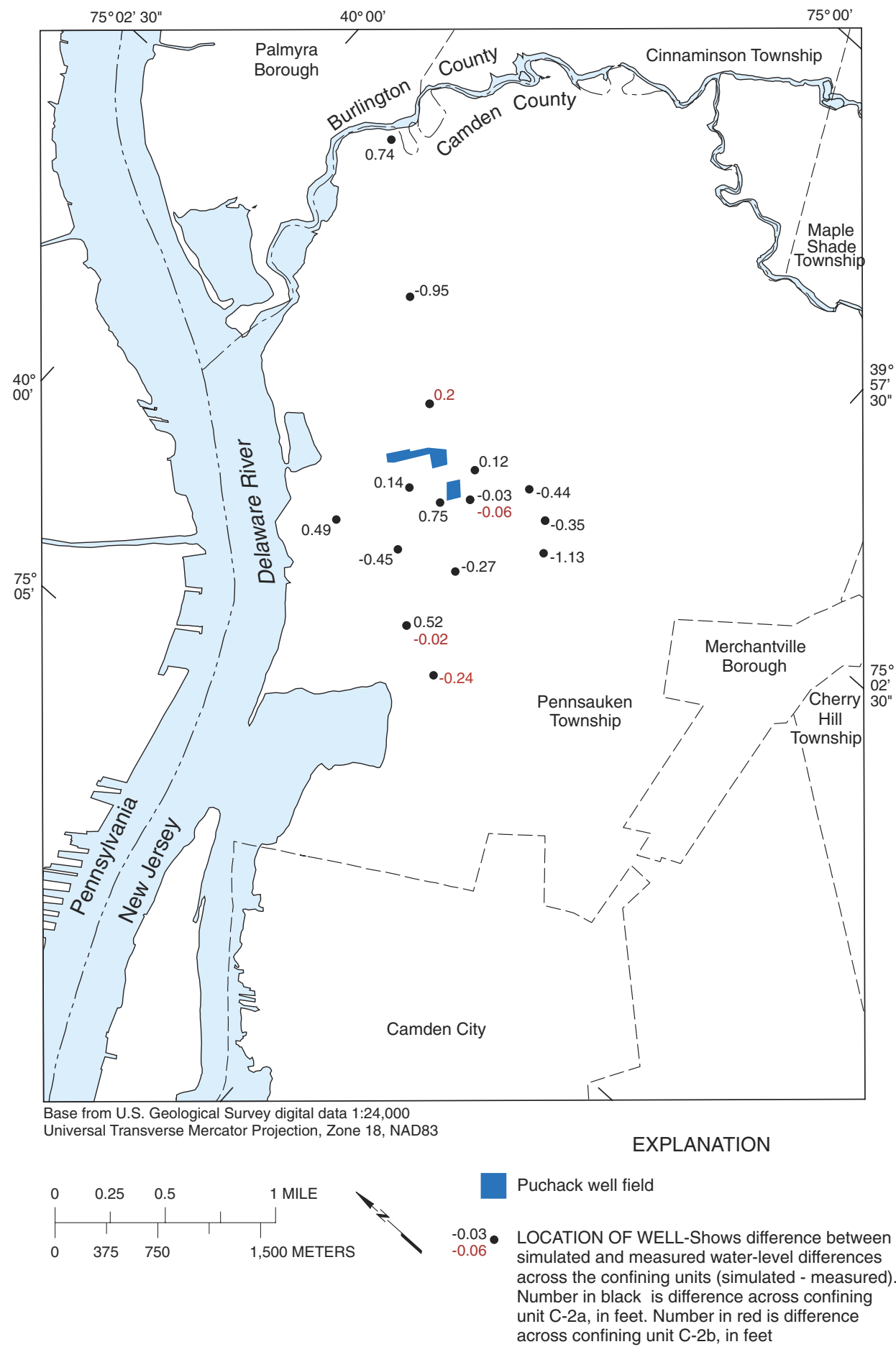

Figure 13. Differences between simulated and measured gradients across confining units C-2a (between the Middle aquifer of the Potomac-Raritan-Magothy aquifer system and the Intermediate sand) and C-2b (between the Intermediate sand and the Lower aquifer of the Potomac-Raritan-Magothy aquifer system), Pennsauken Township and vicinity, Camden County, New Jersey, January-March 1998. 
Table 5. Simulated and measured head differences at nested wells, Pennsauken Township and vicinity, Camden County, New Jersey. [Well locations shown in figure 10; NGVD29, National Geodetic Vertical Datum of 1929]

\begin{tabular}{|c|c|c|c|c|c|c|c|c|}
\hline Nest identifier & $\begin{array}{l}\text { U.S. Geological } \\
\text { Survey well } \\
\text { number }\end{array}$ & $\begin{array}{l}\text { Model layer } \\
\text { (table 2) }\end{array}$ & $\begin{array}{l}\text { Measured altitude } \\
\text { of water level } \\
\text { with respect to } \\
\text { NGVD29 } \\
\text { (feet) }\end{array}$ & $\begin{array}{c}\text { Measured } \\
\text { water-level } \\
\text { difference }^{1} \\
\text { (feet) }\end{array}$ & $\begin{array}{l}\text { Simulated } \\
\text { altitude of water } \\
\text { level with } \\
\text { respect to } \\
\text { NGVD29 } \\
\text { (feet) }\end{array}$ & $\begin{array}{c}\text { Simulated- } \\
\text { water-level } \\
\text { difference } \\
\text { (feet) }\end{array}$ & Residual $^{2}$ & Confining unit \\
\hline CCMW-1 & $\begin{array}{l}7-852 \\
7-851\end{array}$ & $\begin{array}{l}5 \\
7\end{array}$ & $\begin{array}{l}-12.88 \\
-14.00\end{array}$ & -1.12 & $\begin{array}{l}-13.29 \\
-14.68\end{array}$ & -1.39 & -0.27 & $\mathrm{C}-2 \mathrm{a}$ \\
\hline CCMW-4 & $\begin{array}{l}7-856 \\
7-855\end{array}$ & $\begin{array}{r}3 \\
10\end{array}$ & $\begin{array}{l}-12.89 \\
-15.97\end{array}$ & -3.08 & $\begin{array}{l}-13.79 \\
-16.12\end{array}$ & -2.33 & .75 & ${ }^{3} \mathrm{C}-2$ \\
\hline MW-1 & $\begin{array}{l}7-907 \\
7-908 \\
7-906\end{array}$ & $\begin{array}{r}5 \\
7 \\
11\end{array}$ & $\begin{array}{r}-9.34 \\
-10.47 \\
-10.77\end{array}$ & $\begin{array}{l}-1.13 \\
-.3\end{array}$ & $\begin{array}{l}-11.35 \\
-11.96 \\
-12.28\end{array}$ & $\begin{array}{l}-.61 \\
-.32\end{array}$ & $\begin{array}{r}.52 \\
-.02\end{array}$ & $\begin{array}{l}C-2 a \\
C-2 b\end{array}$ \\
\hline MW-3 & $\begin{array}{l}7-911 \\
7-912\end{array}$ & $\begin{array}{r}5 \\
11\end{array}$ & $\begin{array}{l}-14.65 \\
-16.39\end{array}$ & -1.74 & $\begin{array}{l}-14.48 \\
-17.35\end{array}$ & -2.87 & -1.13 & ${ }^{3} \mathrm{C}-2$ \\
\hline MW-4 & $\begin{array}{l}7-913 \\
7-914 \\
7-915\end{array}$ & $\begin{array}{r}5 \\
9 \\
11\end{array}$ & $\begin{array}{l}-14.42 \\
-17.38 \\
-17.32\end{array}$ & $\begin{array}{r}-2.96 \\
.06\end{array}$ & $\begin{array}{l}-14.48 \\
-17.79 \\
-17.79\end{array}$ & $\begin{array}{l}-3.31 \\
0\end{array}$ & $\begin{array}{l}-.35 \\
-.06\end{array}$ & $\begin{array}{l}{ }^{3} \mathrm{C}-2 \\
\mathrm{~A}-3 \mathrm{a}, \mathrm{A}-3 \mathrm{~b}\end{array}$ \\
\hline MW-5 & $\begin{array}{l}7-916 \\
7-917 \\
7-918\end{array}$ & $\begin{array}{r}3 \\
7 \\
10\end{array}$ & $\begin{array}{l}-13.23 \\
-15.82 \\
-15.82\end{array}$ & $\begin{array}{l}-2.59 \\
0\end{array}$ & $\begin{array}{l}-13.98 \\
-16.60 \\
-16.66\end{array}$ & $\begin{array}{r}-2.62 \\
-.06\end{array}$ & $\begin{array}{l}-.03 \\
-.06\end{array}$ & $\begin{array}{l}A-2 c 1, C-2 a \\
C-2 b\end{array}$ \\
\hline MW-6 & $\begin{array}{l}7-919 \\
7-920\end{array}$ & $\begin{array}{r}3 \\
11\end{array}$ & $\begin{array}{l}-13.20 \\
-16.34\end{array}$ & -3.14 & $\begin{array}{l}-14.30 \\
-17.32\end{array}$ & -3.02 & .12 & $\begin{array}{c}\mathrm{A}-2 \mathrm{c} 1, \mathrm{C}-2 \mathrm{a} \\
\mathrm{C}-2 \mathrm{~b}\end{array}$ \\
\hline MW-10 & $\begin{array}{l}7-928 \\
7-929\end{array}$ & $\begin{array}{r}5 \\
11\end{array}$ & $\begin{array}{l}-12.13 \\
-12.65\end{array}$ & -.52 & $\begin{array}{l}-12.95 \\
-13.92\end{array}$ & -.97 & -.45 & ${ }^{3} \mathrm{C}-2$ \\
\hline LFN & $\begin{array}{l}7-964 \\
7-965\end{array}$ & $\begin{array}{l}3 \\
7\end{array}$ & $\begin{array}{r}-8.43 \\
-11.82\end{array}$ & -3.39 & $\begin{array}{l}-10.35 \\
-13.00\end{array}$ & -2.65 & .74 & A-2c1, C-2a \\
\hline LFS & $\begin{array}{l}7-960 \\
7-961\end{array}$ & $\begin{array}{r}5 \\
10\end{array}$ & $\begin{array}{l}-16.57 \\
-16.63\end{array}$ & -.06 & $\begin{array}{l}-16.19 \\
-17.20\end{array}$ & -1.01 & -.95 & ${ }^{3} \mathrm{C}-2$ \\
\hline
\end{tabular}

${ }^{1}$ The water-level difference is the head at the well below the confining unit minus the head at the well above the confining unit. Negative differences indicate a downward gradient.

${ }^{2}$ The residual is the simulated difference minus the measured difference.

${ }^{3} \mathrm{C}-2$ denotes confining unit composed of both C-2a and C-2b. No wells are available to determine the vertical gradient in the Intermediate sand at these locations. 


\section{Simulation of Flow System}

Where necessary, the existing flow model was modified to meet NJDEP guidelines for contributing-area delineations in complex settings (Spayd and Johnson, 2003). These modifications included rediscretizing the model grid in the horizontal direction and preparing the water-use data set for use in delineation as described below. In other cases, however, the calibrated model already met these NJDEP guidelines.

NJDEP guidelines state that the model cell containing the well whose contributing area is to be delineated may not exceed $100 \mathrm{ft}$ in length or width and that the maximum cell size in the model must be less than $500 \mathrm{ft}$ on a side. Modelcell sizes in the calibrated model range from 206 by $219 \mathrm{ft}$ to 412 by $440 \mathrm{ft}$. In the rediscretized model, the smallest cells were 97 by $98 \mathrm{ft}$ and the largest cells, near the model boundaries, remained at 412 by $440 \mathrm{ft}$. The fine grid size is required in order to define the location of the supply well to within $100 \mathrm{ft}$. Reducing the size of the model cells containing wells allows the wells to be located more accurately but does not affect the calibration of the flow model.

NJDEP guidelines also state that the individual model layers may not exceed $100 \mathrm{ft}$ in thickness. The 11 model layers used to account for vertical and horizontal variability in hydraulic parameters in the Puchack model met this criterion.

Ground-water withdrawal data was prepared for input to the revised model. Because withdrawals from the Puchack well field were reduced greatly during the 1980's and ultimately ceased in 1998 due to chromium contamination, the contributing area was delineated using a hypothetical data set. The major difference between the delineation withdrawals data set and the calibration withdrawals data set (January-March 1998) is that the delineation data set is based on the assumption that the wells in the Puchack well field were pumping at full capacity, although this was not actually the case in 1998. Ground-water withdrawal data from surrounding well fields were specified using the average withdrawals for 1998 (listed as "delineation withdrawals" in table 3).

\section{Particle Tracking}

The particle-tracking computer program MODPATH (Pollack, 1994) was used with the rediscretized model to determine the areas on the land surface that contribute flow to the Puchack well field. MODPATH allows a hypothetical particle to be placed at any location within the model. The position of the particle is then calculated at successive intervals of simulated time as it moves through the flow field until it reaches a model boundary or discharge point. To calculate these positions, estimates of porosity are required. Porosity was estimated to be 20 percent for aquifer units and 25 percent for confining units. These values were estimated using typical values for sand and clay units and are similar to NJDEP's recommended value of 25 percent (Spayd and Johnson, 2003).
Nine particles were placed at the surface of each model cell such that each particle would be at the center of a polygon that subdivides the model cell into three polygons along both the row and the column. This procedure effectively subdivides each cell into nine polygons for contributing-area delineation. The particles were then forward-tracked until they terminated, either by discharging to a well or by reaching a model boundary (flow boundary or the river). MODPATH particle starting locations and the cell at which the flow path terminated were converted to Geographic Information System (GIS) data using MODTOOLS (Orzol, 1997). Results were analyzed to identify starting locations of particles that terminated at any of the Puchack wells. Tier designations were assigned using the travel time computed by the particle-tracking program. This approach allowed the delineation of the contributing areas and tiers to be finer and smoother than that achieved by using the original model-grid cells. The same approach was used to delineate the contributing area to each individual well in the Puchack well field by grouping the data on the basis of the particular well to which the particle discharged.

\section{Contributing Area}

The contributing area for the Puchack well field determined by using the rediscretized model and the delineation water-use data set described in the previous section is shown in figure 14. The three tiers required for delineation of a Well Head Protection Area are shown, as well as the well-field contributing area from which the travel time was greater than 12 years. The effect of withdrawals from nearby well fields on the contributing area to the Puchack well field is the capture of the areas updip from the Puchack well field by the Morris and Delair well fields (commonly referred to in combination as the Morris/Delair well field) operated by the City of Camden Water Department. A large percentage of the withdrawals from these well fields is derived from the Delaware River; consequently, the Puchack well field intercepts flow from the Delaware River only in a small strip between the Morris and Delair well fields (travel time less than 2 yrs) and from areas south of the Morris/Delair well field. The particle-tracking results indicate the necessity to use the three-dimensional flow model to delineate the contributing area accurately. If the effects of withdrawals from the Morris/Delair well field had not been considered, the resulting contributing area would have been smaller because the Puchack well field would have received more flow from the Delaware River. In contrast, if the contribution from the Delaware River had not been considered, the area contributing water to the Puchack well field would have been larger than the area shown in figure 14.

The individual contributing areas for the six wells in the Puchack well field are shown in figure 15. The contributing areas for Puchack 1 and Puchack 2 are much smaller than those for the other wells because these wells are nearest the river and therefore receive a larger percentage of their withdrawals from the river. 


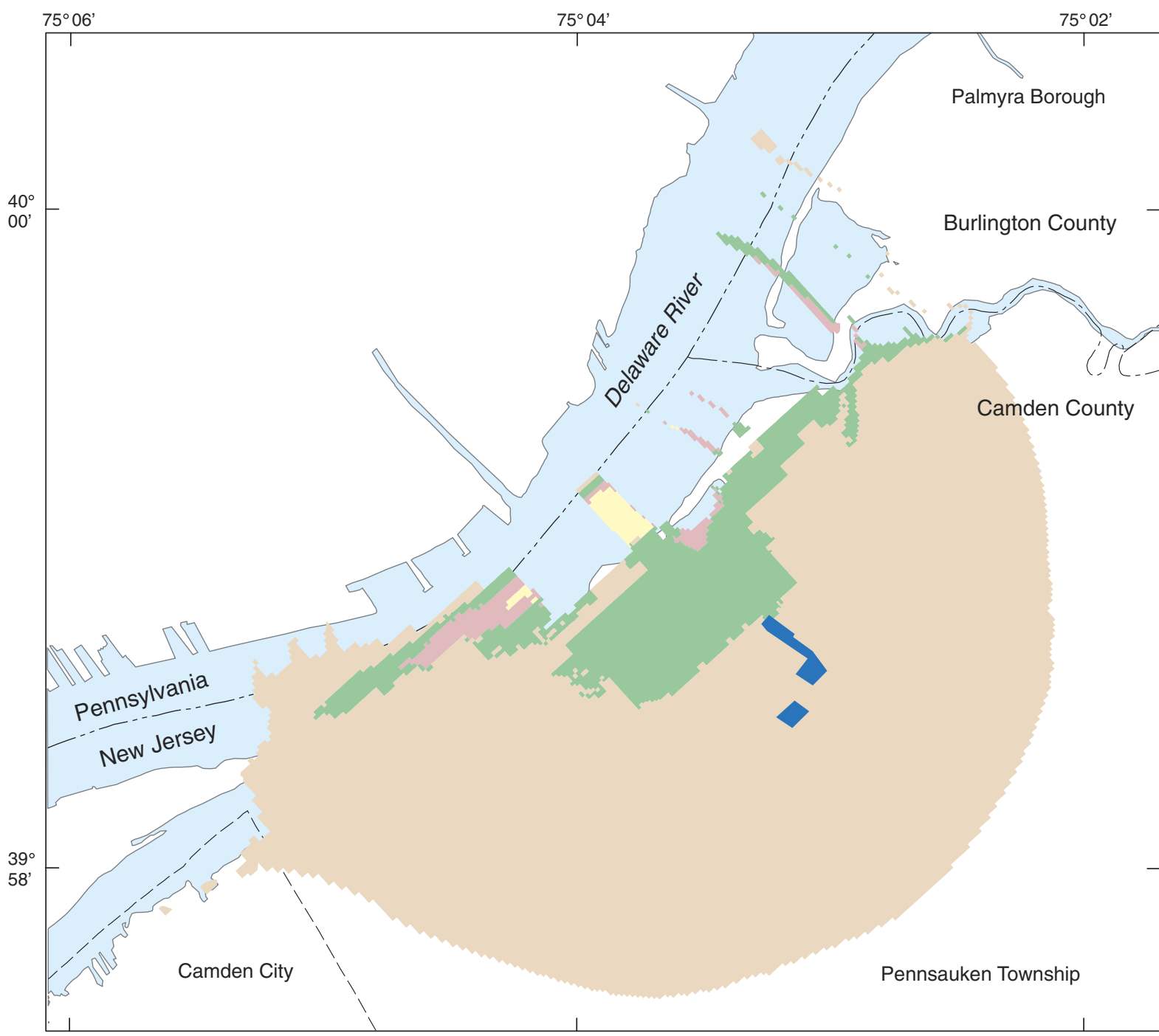

Base from U.S. Geological Survey digital data 1:24,000 Universal Transverse Mercator Projection, Zone 18, NAD83

EXPLANATION

Puchack well field

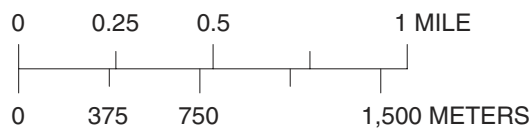

TRAVEL TIME, IN YEARS

Less than or equal to 2

Greater than 2 to 5

Greater than 5 to 12

Greater than 12

Figure 14. Simulated contributing area to the Puchack well field in the delineation simulation, Pennsauken Township and vicinity, Camden County, New Jersey. 

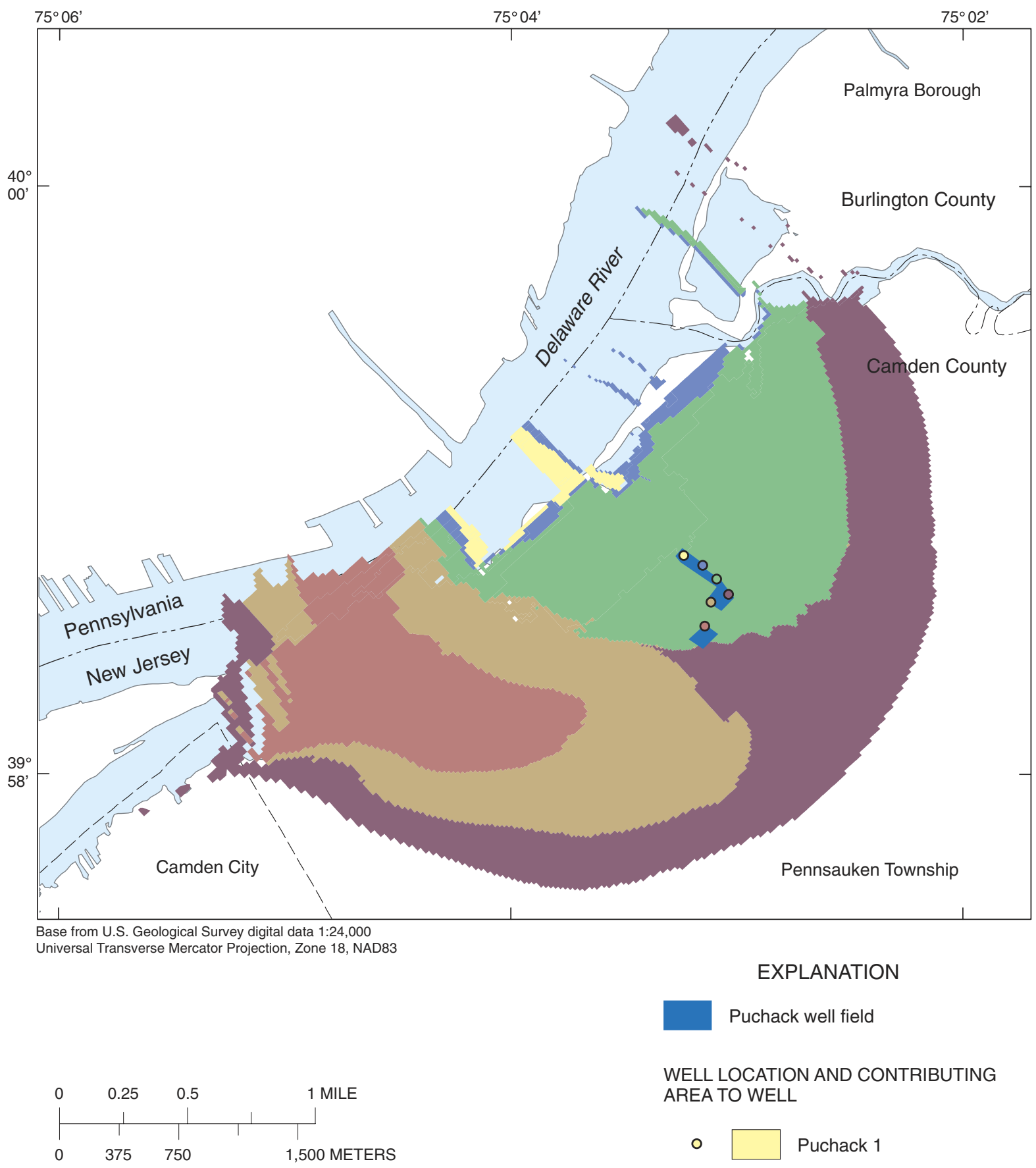

WELL LOCATION AND CONTRIBUTING AREA TO WELL
○ $\square$ Puchack 1
○ $\quad$ Puchack 2
○ $\square$ Puchack 3
○ $\square$ Puchack 5
○ $\square$ Puchack 6
○ $\quad$ Puchack 7

Figure 15. Simulated contributing area to individual wells in the Puchack well field, Pennsauken Township and vicinity, Camden County, New Jersey. 


\section{Uncertainty Analysis}

An uncertainty analysis was conducted to demonstrate the effects of changing model-input parameters on the simulated contributing area to the Puchack well field. The set of parameters used in a flow-model calibration is not unique. Different combinations of parameters could be used to obtain model results that meet the calibration criteria. Therefore, variations in model-input parameters can have a substantial effect on the size and shape of the contributing area without necessarily invalidating the model calibration.

\section{Approach}

For this analysis, the model parameters were adjusted individually until the head change would result in a model that could no longer be considered "calibrated." The parameters and the range over which they were varied are listed in table 6. In most cases, the "appropriate range" (referred to in Spayd and Johnson, 2003) to be considered in the evaluation of model sensitivity to parameter values was determined by calculating the change (increase and decrease) in each parameter that would result in a maximum head change of $\pm 5 \mathrm{ft}$ (the model-calibration criterion for heads) anywhere in the active model area.

For five parameters related to recharge, withdrawals, and porosity, the 5 -ft criterion was not applicable. For these parameters, values were changed as described below. Porosity could not be evaluated using the 5 - $\mathrm{ft}$ criterion because porosity is not used in the flow model and does not affect the simulated heads; however, porosity is important in the determination of ground-water travel times. In the uncertainty analysis, porosity was varied by \pm 5 percent.

To evaluate the effects of variations in ground-water withdrawals, the well field that would have the largest effect on the contributing area of the Puchack well field (the Morris/ Delair well field) was selected. Wells in the Morris/Delair well field are along the Delaware River and Pennsauken Creek, a tributary. Simulation results show that wells in the southern part of the well field receive a larger percentage of flow from the Delaware River than do wells in the northern part of the well field. To bracket possible effects of pumping from the Morris/Delair well field, two distributions of withdrawals were simulated in which all of the withdrawals from the well field were attributed to wells in either the northern or the southern part of the well field.

To evaluate the effect of applying a uniform recharge rate (rather than the spatially varied rate used in the calibrated model), a uniform recharge rate was calculated to provide the same recharge as in the calibrated model. The 5 -ft threshold was applicable to this change. Once specified, however, the uniform recharge was both increased and decreased until the 5 -ft criterion was met.

\section{Effects of Model-Input Parameter Values on Contributing Areas}

Thirty-six simulations were made in which individual parameter values were varied. The 5 -ft head-change criterion was used to evaluate the ranges of values for horizontal and vertical hydraulic conductivity, riverbed hydraulic conductivity, and some recharge parameters. The final model parameter estimates and the percentage increases and decreases to each parameter required to cause a \pm 5 -ft maximum head change for these runs are shown in table 6 . The magnitude of the percent increases and decreases can be used as an indicator of model sensitivity to that parameter. Variations in parameters to which the 5-ft head-change criterion was not applied also are shown in table 6.

Contributing areas were delineated for each of the model runs shown in table 6 . The resulting contributing areas were compared visually with the contributing area to the Puchack well field from the delineation simulation (fig. 14). Contributing areas from several selected model runs are shown in figures 16 through 25 . In general, these model runs were selected as examples because of large differences in the shape, size, or tier distribution of the contributing area from that of the basic delineation.

\section{Porosity}

Porosity had the greatest effect on the size and shape of the contributing area associated with each of the travel-time tiers. Changes to porosity changed the time required for individual particles to reach the well field. Decreasing the porosity to 15 percent in aquifers and 20 percent in confining units (fig. 17) expanded the size of the contributing areas associated with the 2-to-5-year and 5-to-12-year travel times, because the particle velocity increases as porosity decreases.

\section{Withdrawals}

The distribution of withdrawals from the Morris/Delair well field also affected the size and shape of the contributing area to the Puchack well field. When all of the withdrawals were applied to the wells in the northern part of the well field (fig. 18), the contributing area was similar to that in the delineation simulation except that the area in the Delaware River immediately updip from the well field with a travel time of 2 to 5 years was larger (wider). Also, compared to the delineation simulation, a greater percentage of the withdrawals from the Puchack well field was derived from the Delaware River. When all of the withdrawals were applied to the southern part of the Morris/Delair well field (fig. 19), the area of the 2-to5 -year travel-time zone updip from the well field was smaller and the overall contributing area was larger (especially north of the well field). In this case, a smaller percentage of the withdrawals from the Puchack well field was derived from the river and a greater percentage was derived from areas north of the Puchack well field. 


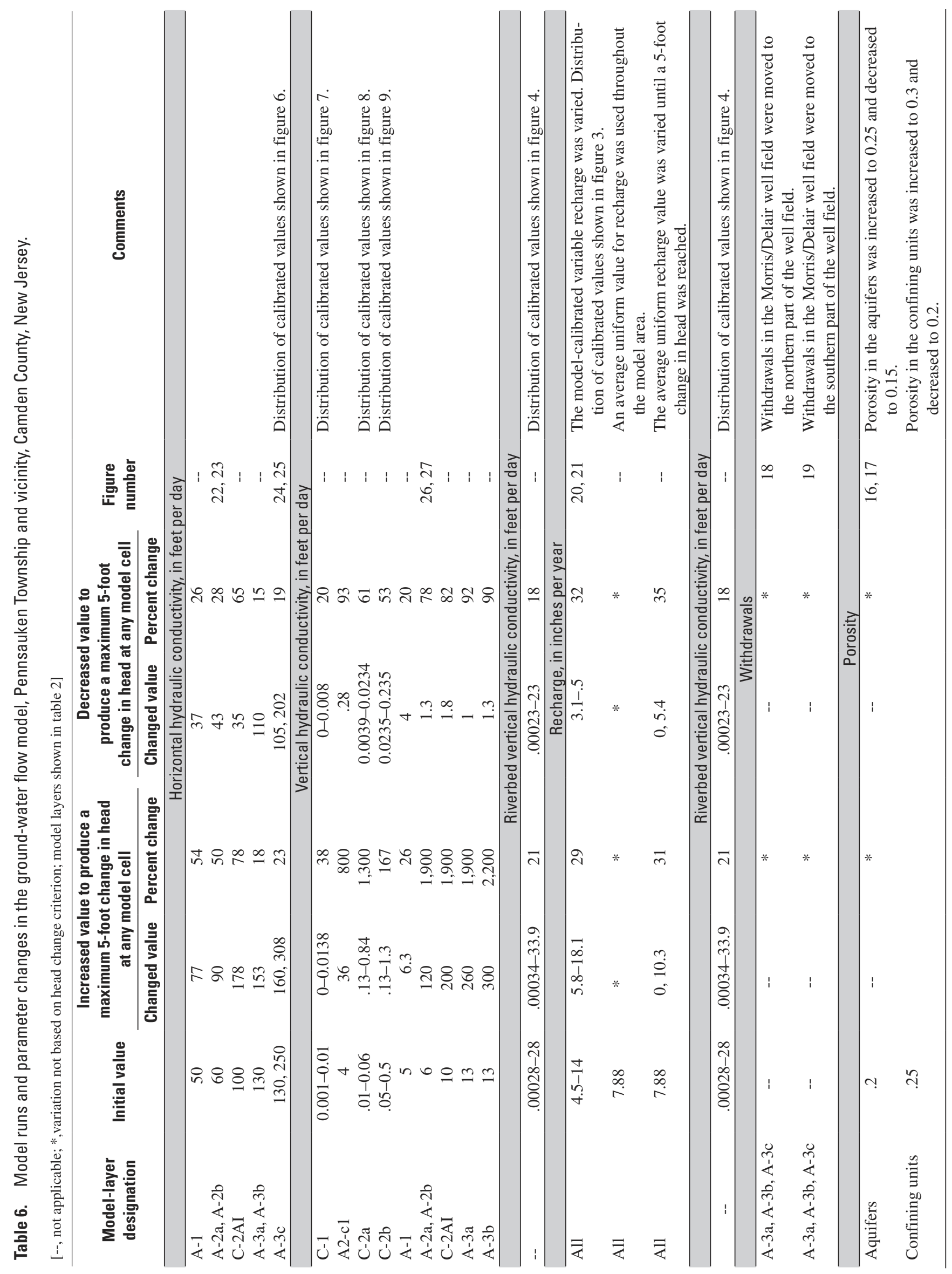




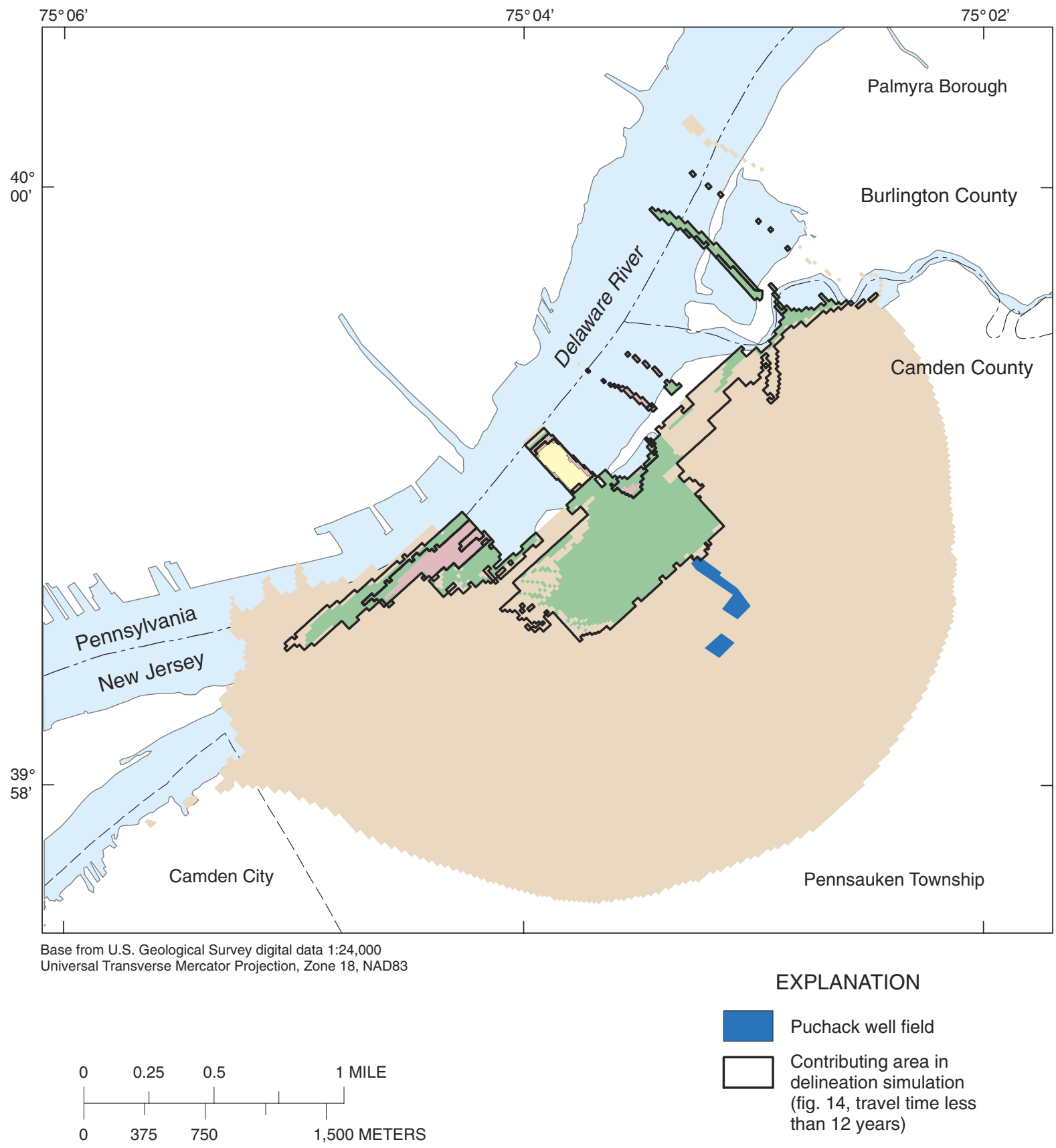

TRAVEL TIME, IN YEARS

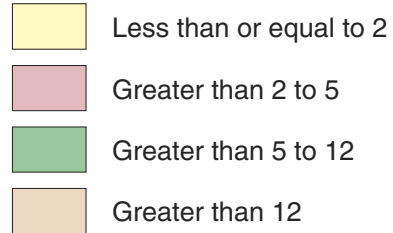

Figure 16. Simulated contributing area to Puchack well field when porosity is increased to 25 percent in aquifers and 30 percent in confining units, Pennsauken Township and vicinity, Camden County, New Jersey. 


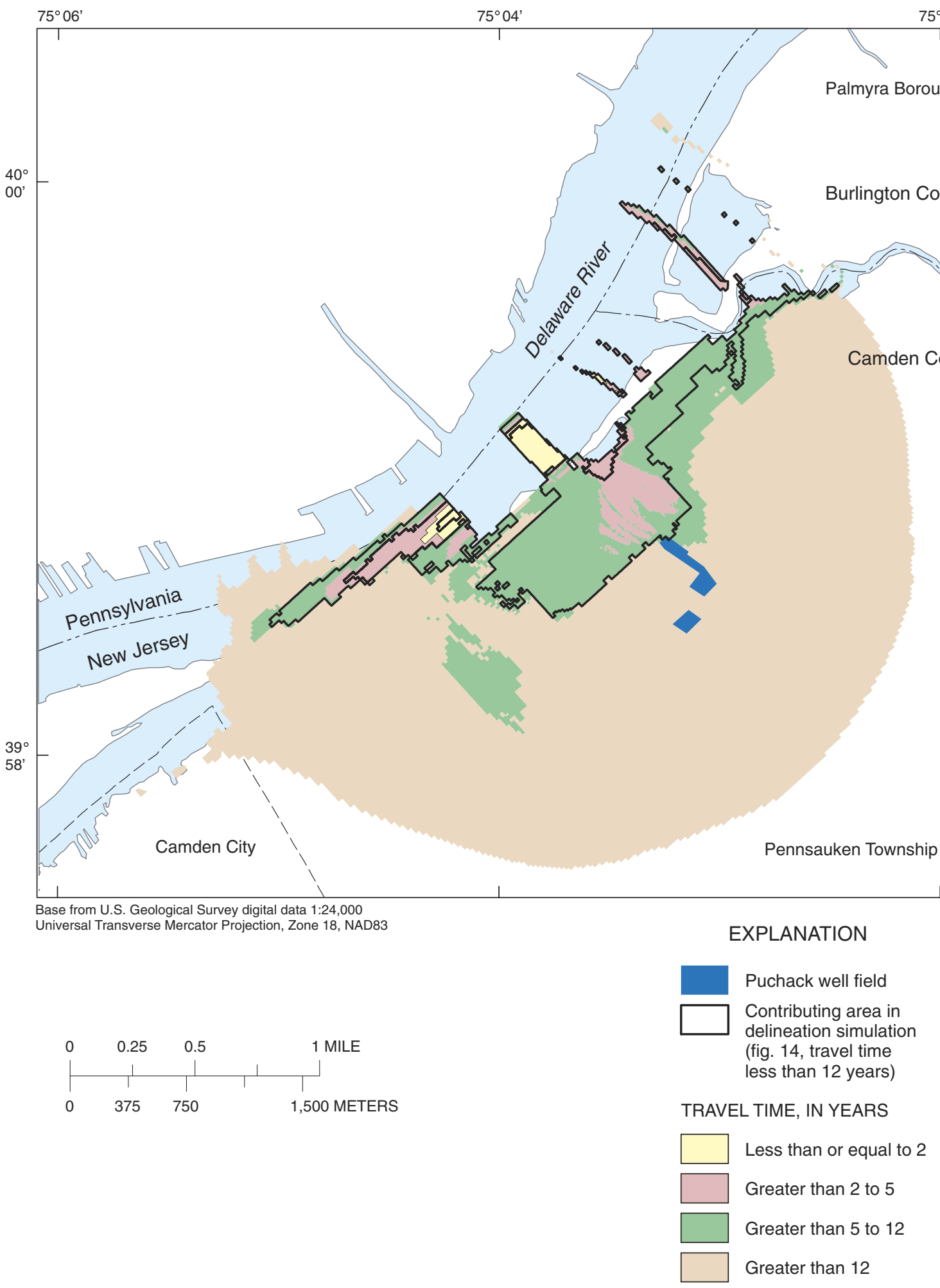

Figure 17. Simulated contributing area to Puchack well field when porosity is decreased to 15 percent in aquifers and 20 percent in confining units, Pennsauken Township and vicinity, Camden County, New Jersey. 


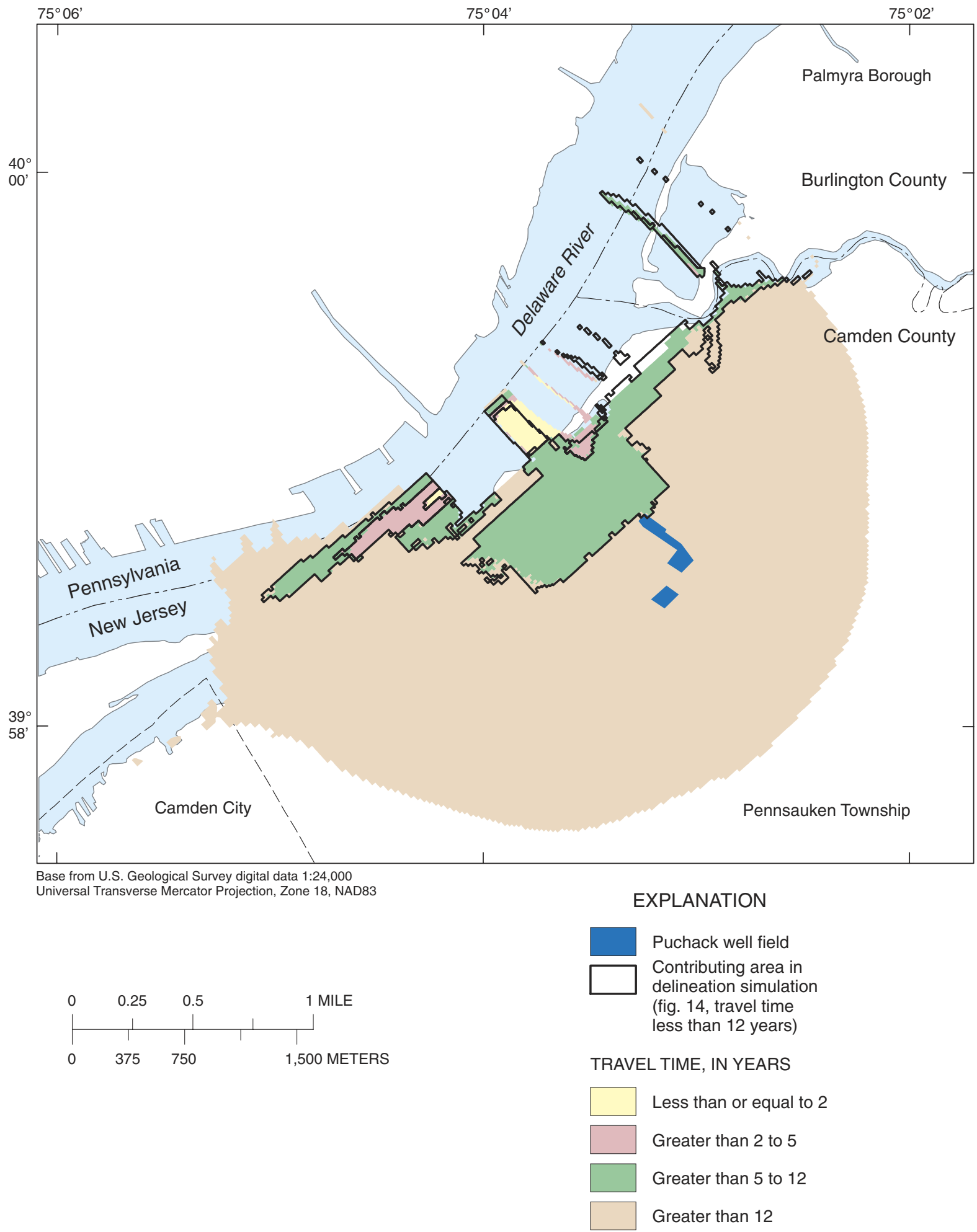

Figure 18. Simulated contributing area to Puchack well field when withdrawals at the Morris/Delair well field are distributed in the northern part of the well field, Pennsauken Township and vicinity, Camden County, New Jersey. 


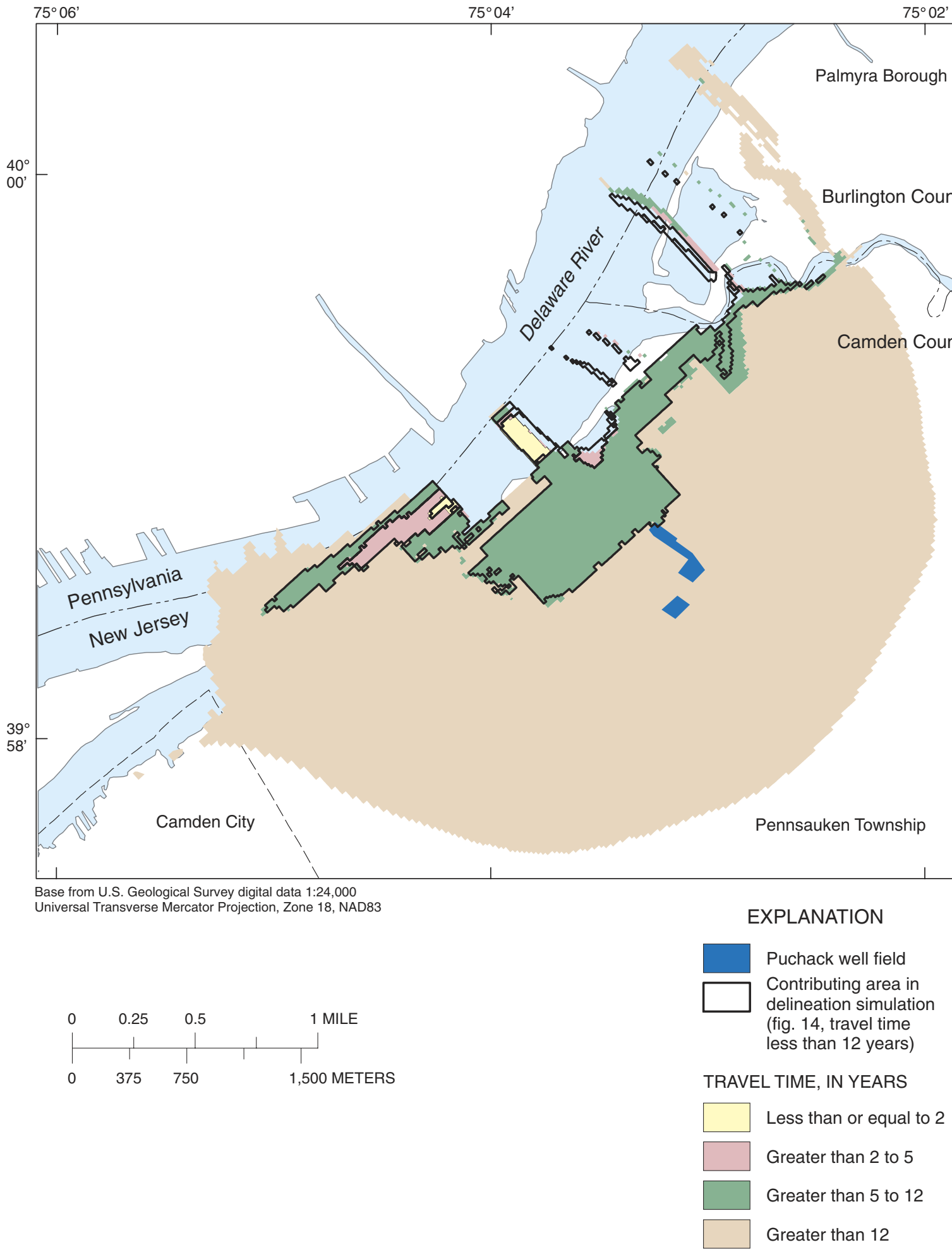

Figure 19. Simulated contributing area to Puchack well field when withdrawals at the Morris/Delair well field are distributed in the southern part of the well field, Pennsauken Township and vicinity, Camden County, New Jersey. 

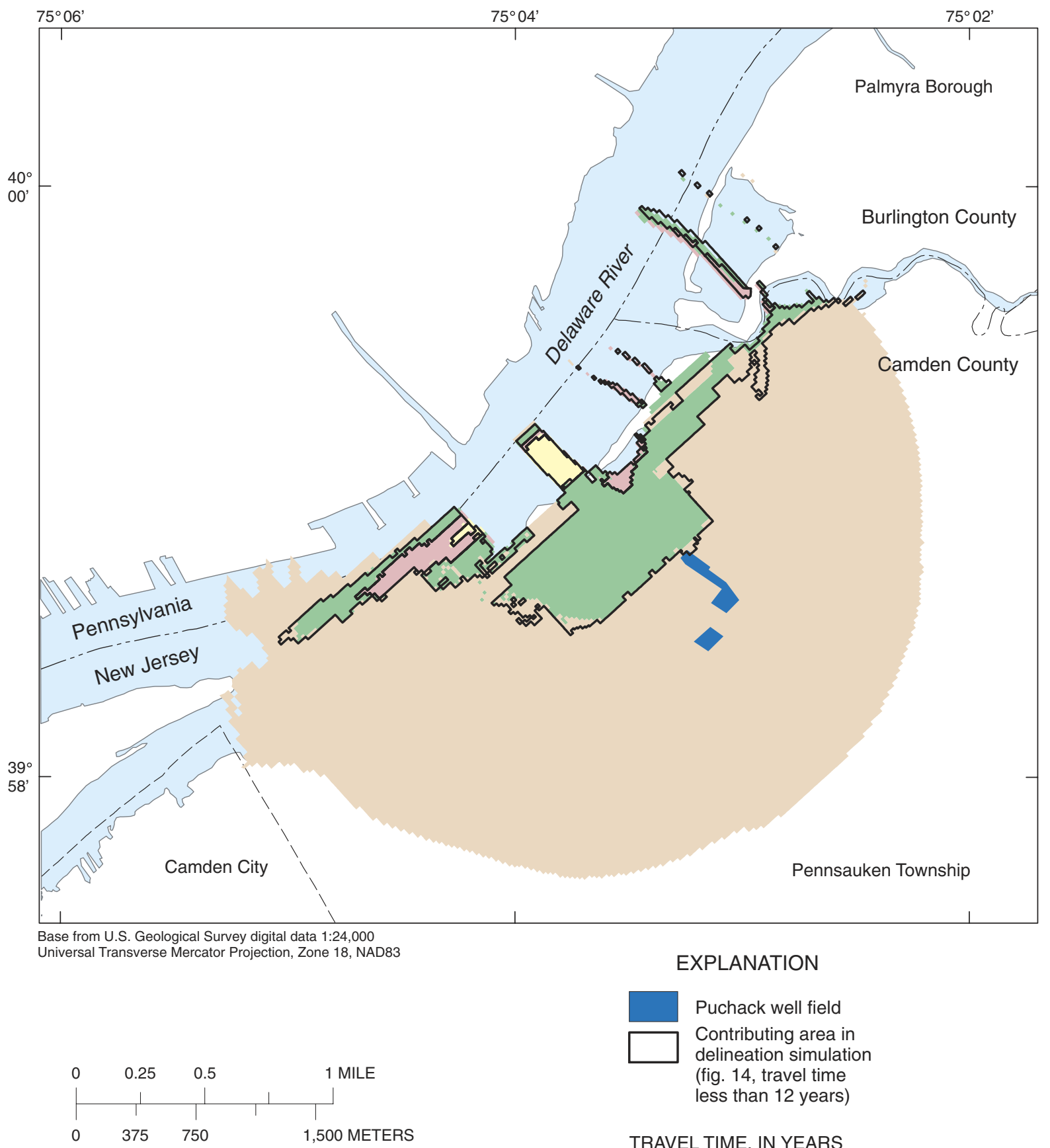

Puchack well field

Contributing area in delineation simulation (fig. 14, travel time less than 12 years)

TRAVEL TIME, IN YEARS

Less than or equal to 2

Greater than 2 to 5

Greater than 5 to 12

Greater than 12

Figure 20. Simulated contributing area to Puchack well field when recharge is increased 29 percent, Pennsauken Township and vicinity, Camden County, New Jersey. 


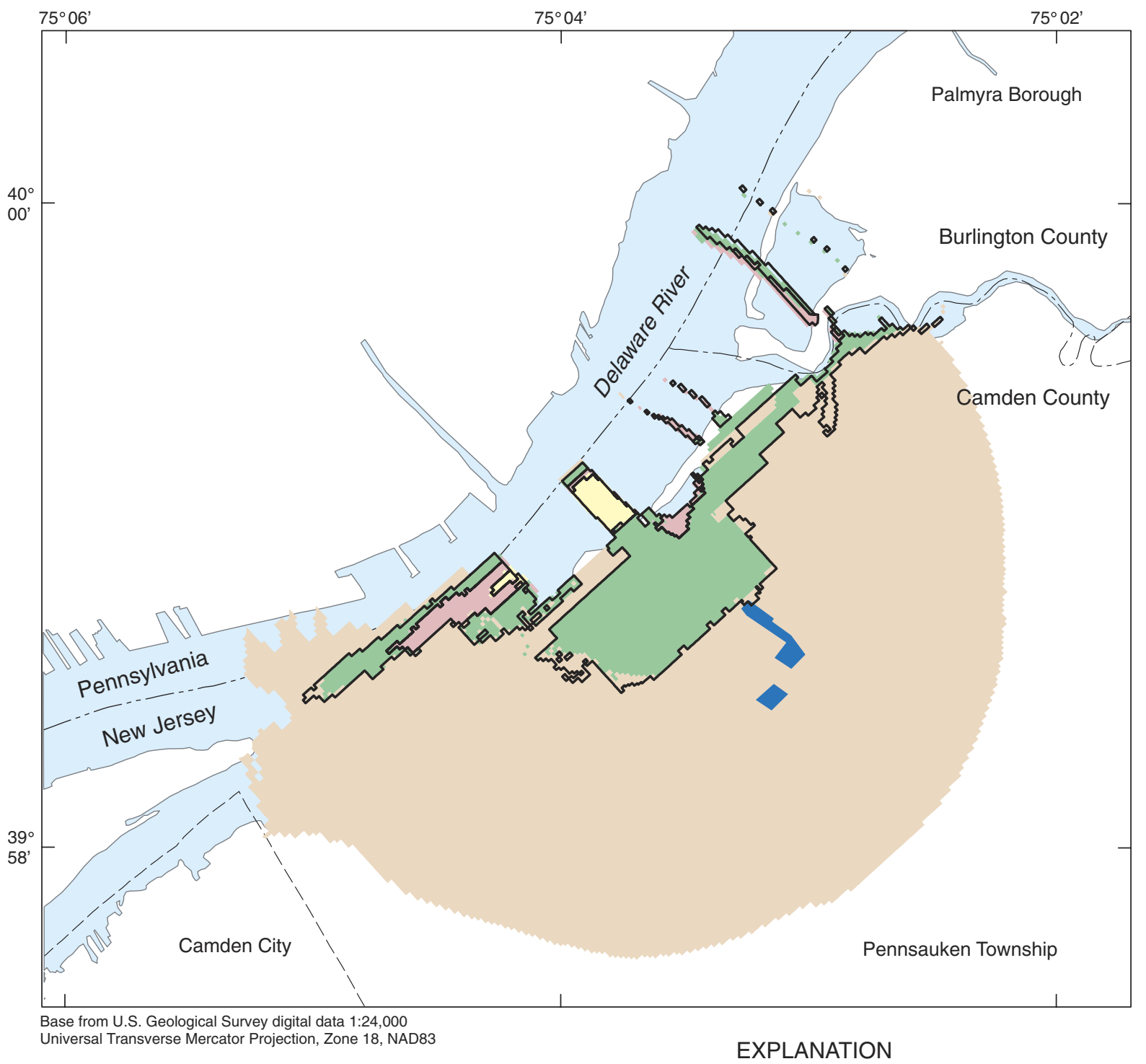

Puchack well field

Contributing area in delineation simulation (fig. 14, travel time

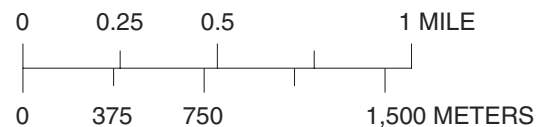
less than 12 years)

TRAVEL TIME, IN YEARS

Less than or equal to 2

Greater than 2 to 5

Greater than 5 to 12

Greater than 12

Figure 21. Simulated contributing area to Puchack well field when recharge is decreased 32 percent, Pennsauken Township, Camden County, New Jersey. 

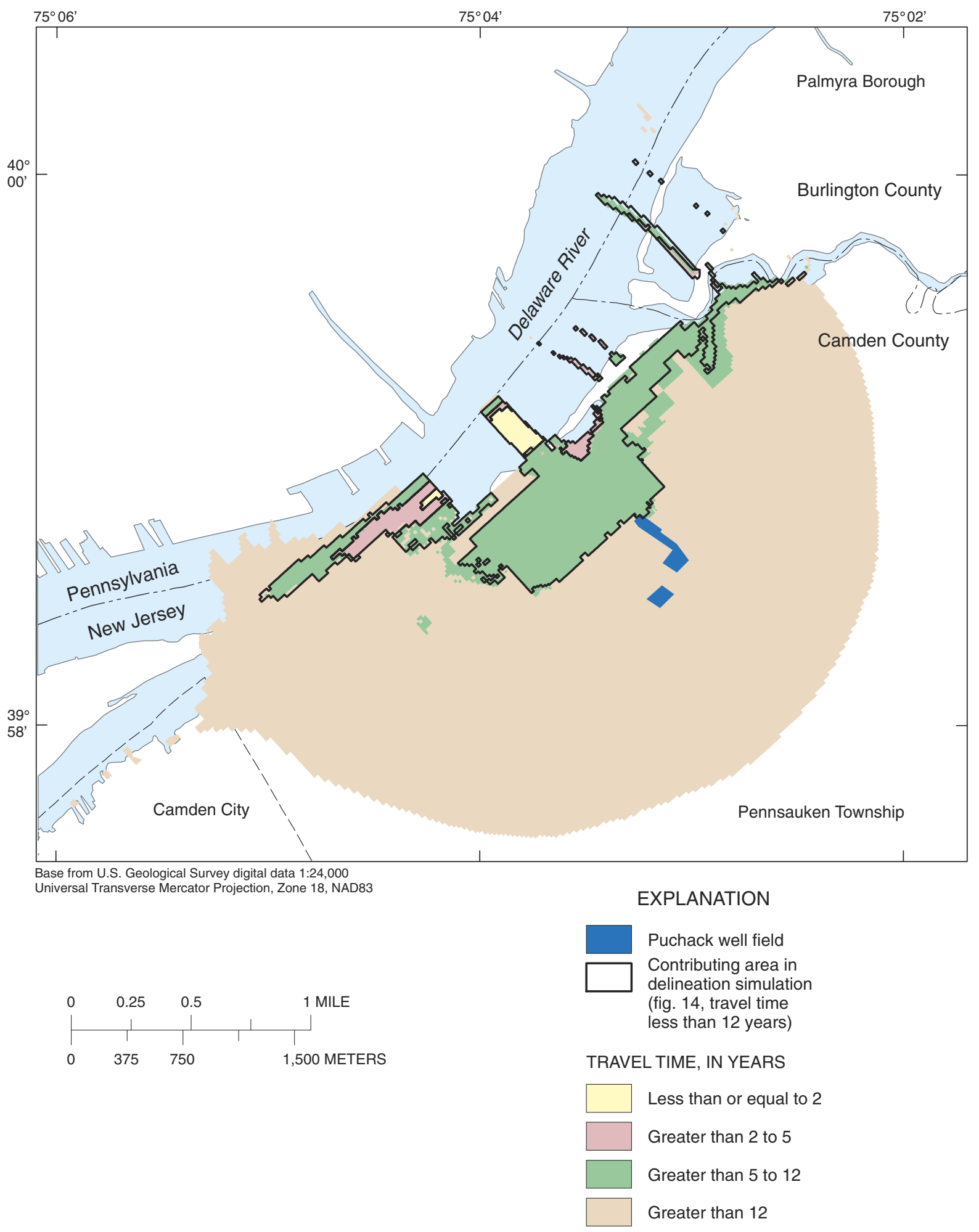

Figure 22. Simulated contributing area to Puchack well field when the hydraulic conductivity of the Middle aquifer of the Potomac-Raritan-Magothy aquifer system is increased 50 percent, Pennsauken Township and vicinity, Camden County, New Jersey. 


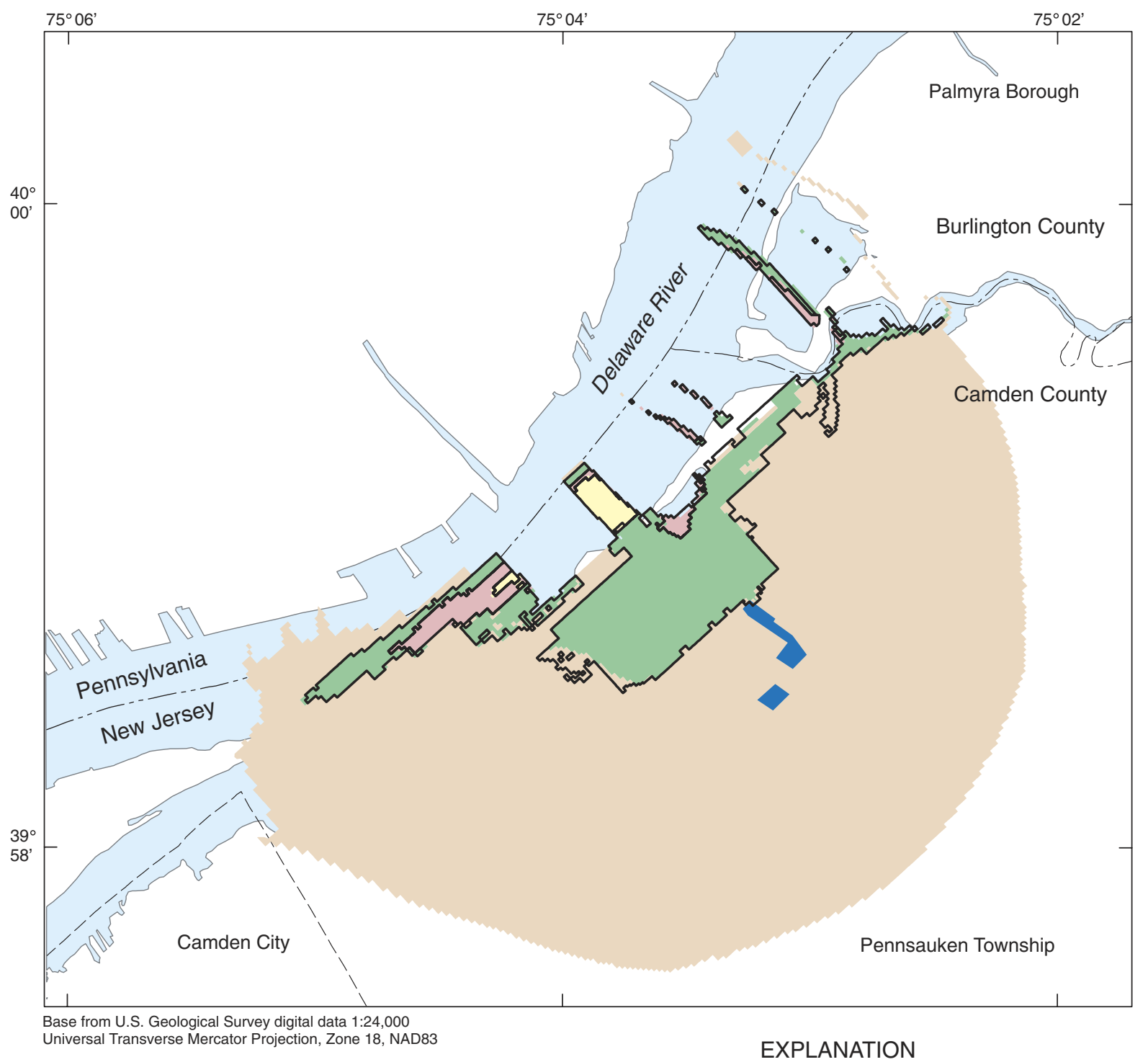

Puchack well field Contributing area in delineation simulation (fig. 14, travel time less than 12 years)

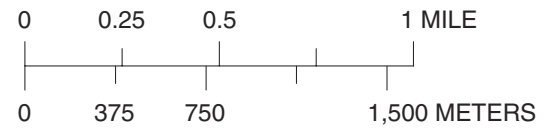

TRAVEL TIME, IN YEARS

Less than or equal to 2

Greater than 2 to 5

Greater than 5 to 12

Greater than 12

Figure 23. Simulated contributing area to Puchack well field when the hydraulic conductivity of the Middle aquifer of the Potomac-Raritan-Magothy aquifer system is decreased 28 percent, Pennsauken Township and vicinity, Camden County, New Jersey. 


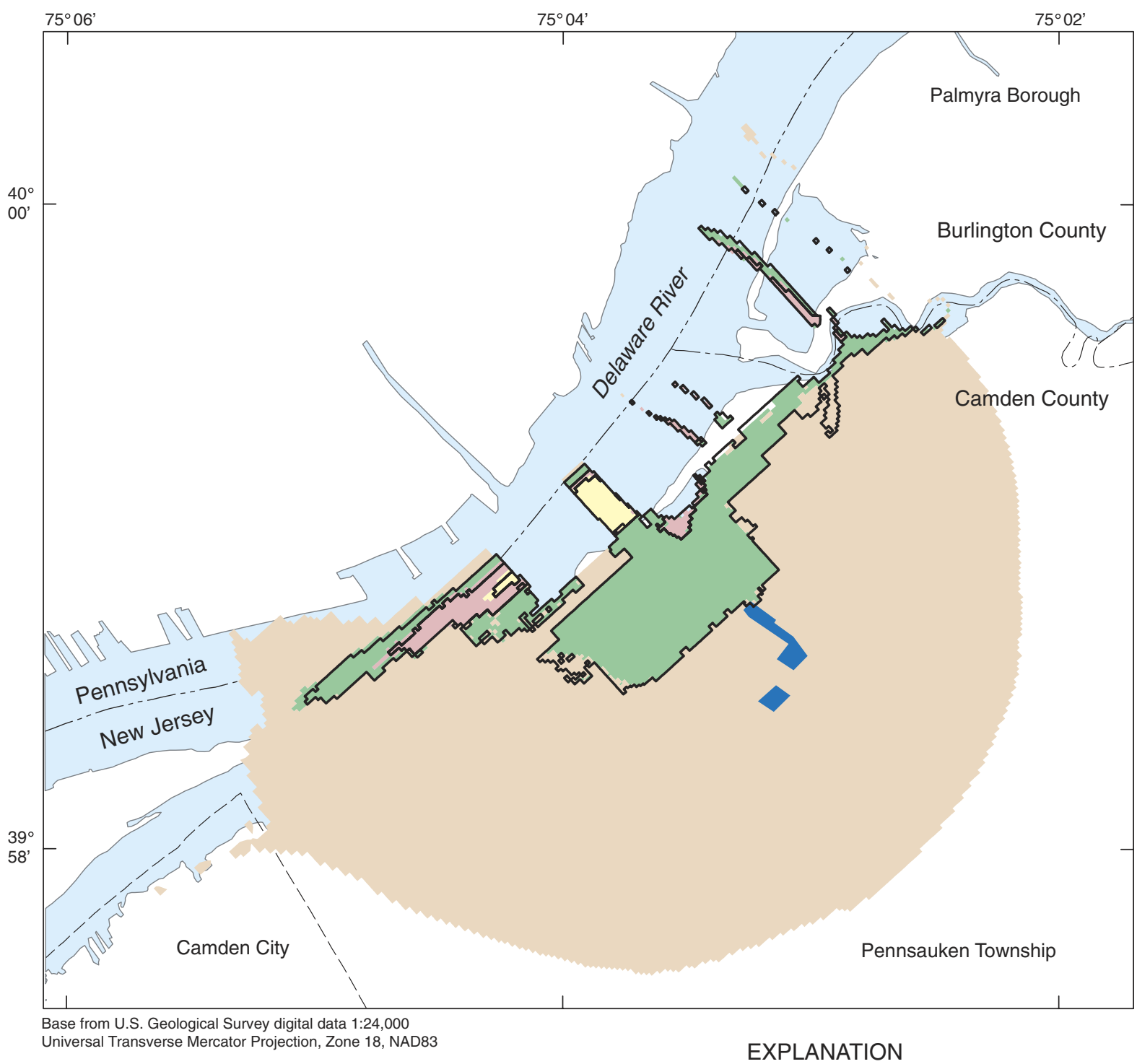

Puchack well field

Contributing area in delineation simulation (fig. 14, travel time less than 12 years)

TRAVEL TIME, IN YEARS

Less than or equal to 2

Greater than 2 to 5

Greater than 5 to 12

Greater than 12

Figure 24. Simulated contributing area to Puchack well field when the hydraulic conductivity of the Lower aquifer of the Potomac-Raritan-Magothy aquifer system (model layer A-3c) is increased 23 percent, Pennsauken Township and vicinity, Camden County, New Jersey. 

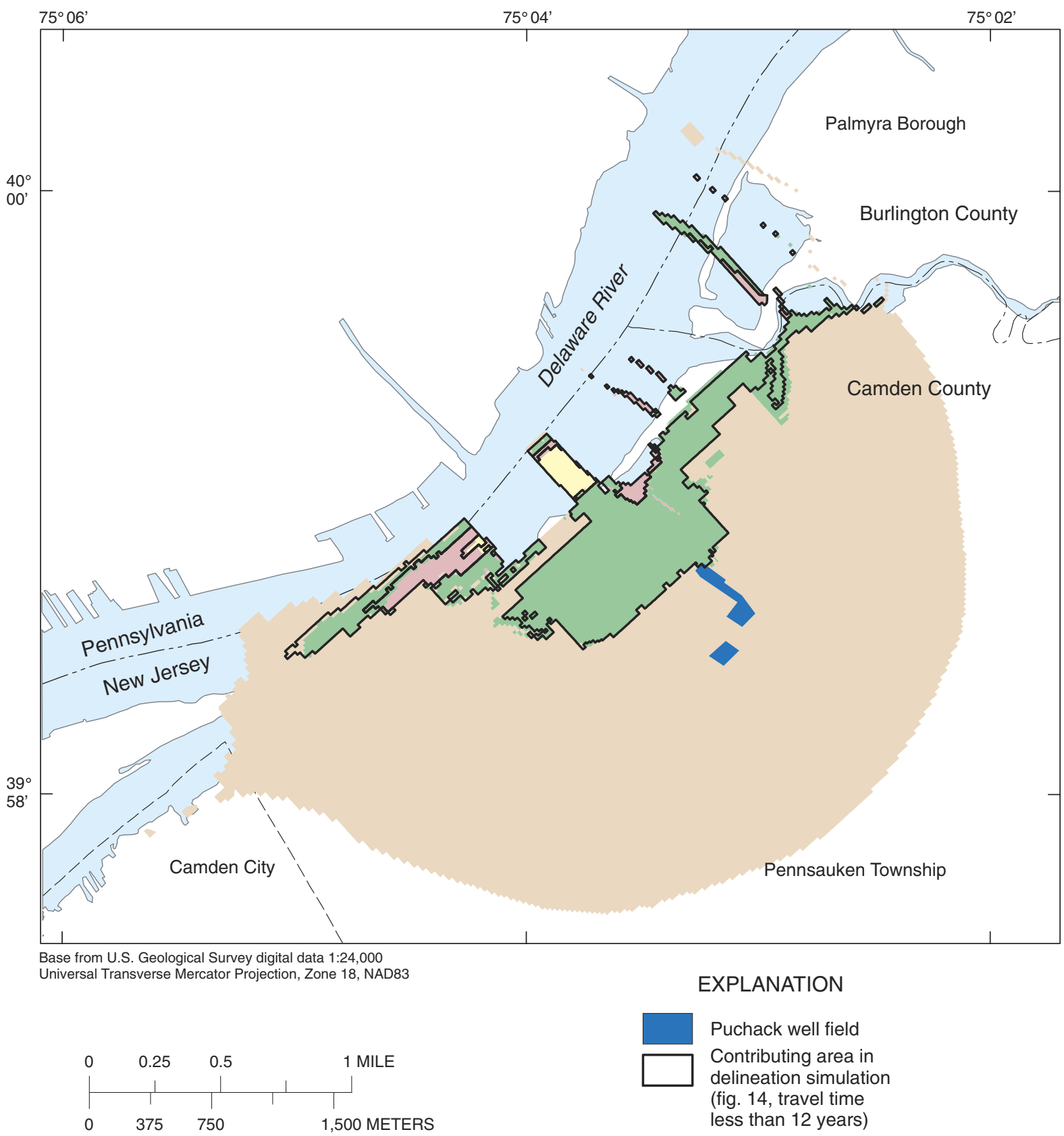

Puchack well field

Contributing area in delineation simulation (fig. 14, travel time less than 12 years)

TRAVEL TIME, IN YEARS

Less than or equal to 2

Greater than 2 to 5

Greater than 5 to 12

Greater than 12

Figure 25. Simulated contributing area to Puchack well field when the hydraulic conductivity of the Lower aquifer of the Potomac-Raritan-Magothy aquifer system (model layer A-3c) is decreased 19 percent, Pennsauken Township and vicinity, Camden County, New Jersey. 


\section{Recharge}

Increasing recharge decreased the size of the area contributing water from the Delaware River for both the 2-to-5-year and 5-to-12-year travel-time zones (fig. 20). Conversely, decreasing recharge increased the contribution from the river and decreased the area of the 5-to-12-year travel-time zone (fig. 21).

\section{Hydraulic Conductivity}

Changes in the hydraulic conductivity of the Middle aquifer (units A-2a and A-2b) and of unit A-3c in the Lower aquifer (figs. 22-25) caused changes in the sizes of the travel-time tiers of the contributing areas as well as in the percent changes required to cause a 5 -ft change in simulated water levels for the variables (table 6). Changes in the horizontal hydraulic conductivity of the Lower aquifer affect the contributing area to the Puchack well field by controlling flow between the Lower aquifer and the Delaware River.

Hydraulic conductivity affects the contributing areas because, as shown by particle-tracking analysis using the flow model, about 80 percent of the water supplying the Puchack well field comes from the Delaware River, and the hydraulic conductivity of the Lower aquifer is high and the hydraulic connection between the Lower aquifer and the riverbed sediments is good. Therefore, the model was sensitive to changes in the hydraulic conductivity of the Lower aquifer.

\section{Vertical Hydraulic Conductivity}

The vertical hydraulic conductivity of the Upper and Middle aquifers (A1, A-2a, and A-2b) and the vertical hydraulic conductivity of the confining unit overlying the Middle aquifer (C1) affect the contributing area to the Puchack well field by controlling flow between the Lower aquifer and areas where recharge is applied (away from the river). The vertical hydraulic conductivities of these units are important because they control vertical flow in the vicinity of the well field; vertical flow in the vicinity of the well field supplies about 20 percent of flow to the Puchack well field (as estimated from particle-tracking results).

As the vertical hydraulic conductivities of the upper units (A1, C1, A-2a, and A-2b) increase, more water comes from the recharge applied at the land surface and the sizes of the contributing areas away from the Delaware River increase (fig. 26). The area of the 12-year travel-time tier is smaller in the simulation when the vertical hydraulic conductivity of the Middle aquifer units is decreased (fig. 27) than in any of the other 36 simulations. In general, the model was sensitive to changes in the vertical hydraulic conductivity of the uppermost units in the model (A1, C1, C-2a, and C-2b).

\section{Aggregate Contributing Area}

The results of the uncertainty analysis described above were used to determine the aggregate contributing area to the Puchack well field. Particle starting locations, termination sites, and travel times from the particle-tracking analysis for the delineation simulation (1 run) and for each of the model runs in which model-input data were varied (36 runs) were combined. The combined data were grouped by particle starting location. The number of times (out of 37) each area contributed flow to the Puchack well field with travel times less than 12 years was determined (fig. 28). Variations in the contributing area to the Puchack well field due to changes in model-parameter values were relatively small. Taken together, the areas that contributed flow to the Puchack well field in at least 31 of the simulations most closely match the size and shape of the contributing area in the delineation simulation.

The aggregate contributing area that accounts for the uncertainty in the model is shown in figure 29. The travel times shown are the shortest travel times that occurred for each area. The shape of the aggregate contributing area is most similar to that resulting from the run in which porosity was decreased (fig. 17), because changes in porosity had a substantial effect on travel time. 


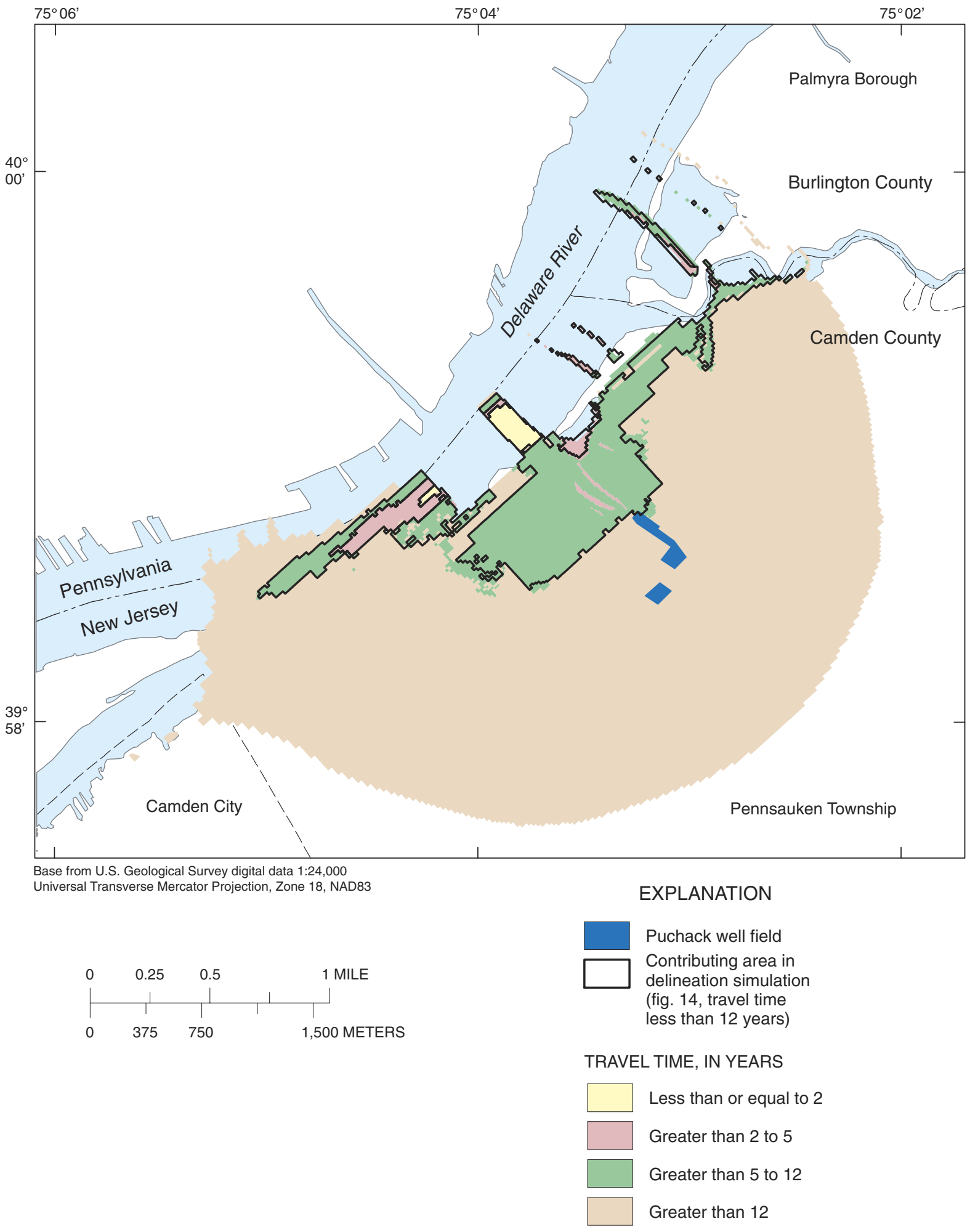

Figure 26. Simulated contributing area to Puchack well field when the vertical hydraulic conductivity of the Middle aquifer of the Potomac-Raritan-Magothy aquifer system is increased 1,900 percent, Pennsauken Township and vicinity, Camden County, New Jersey. 


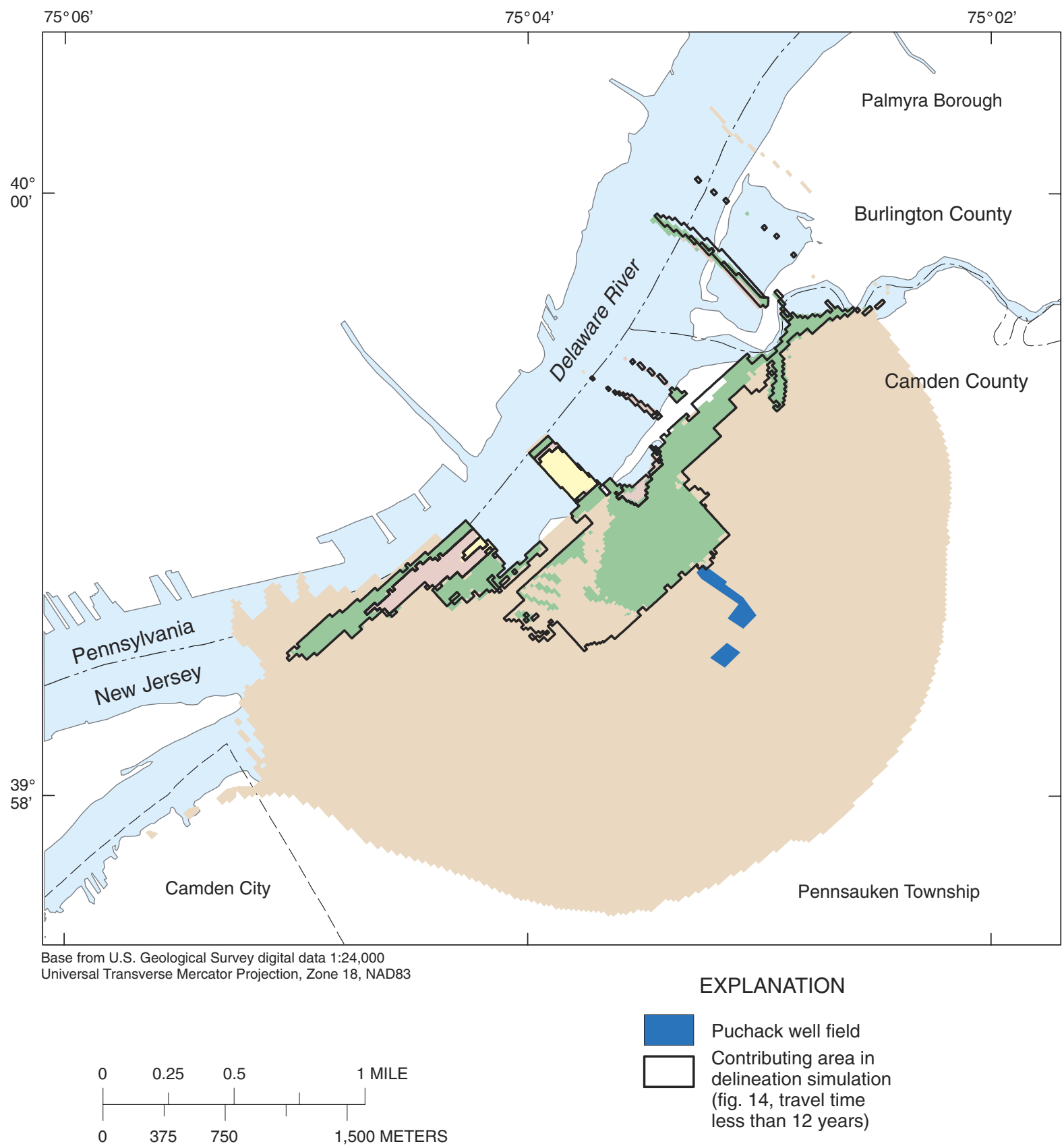

TRAVEL TIME, IN YEARS

Less than or equal to 2

Greater than 2 to 5

Greater than 5 to 12

Greater than 12

Figure 27. Simulated contributing area to Puchack well field when the vertical hydraulic conductivity of the Middle aquifer of the Potomac-Raritan-Magothy aquifer system is decreased 78 percent, Pennsauken Township and vicinity, Camden County, New Jersey. 

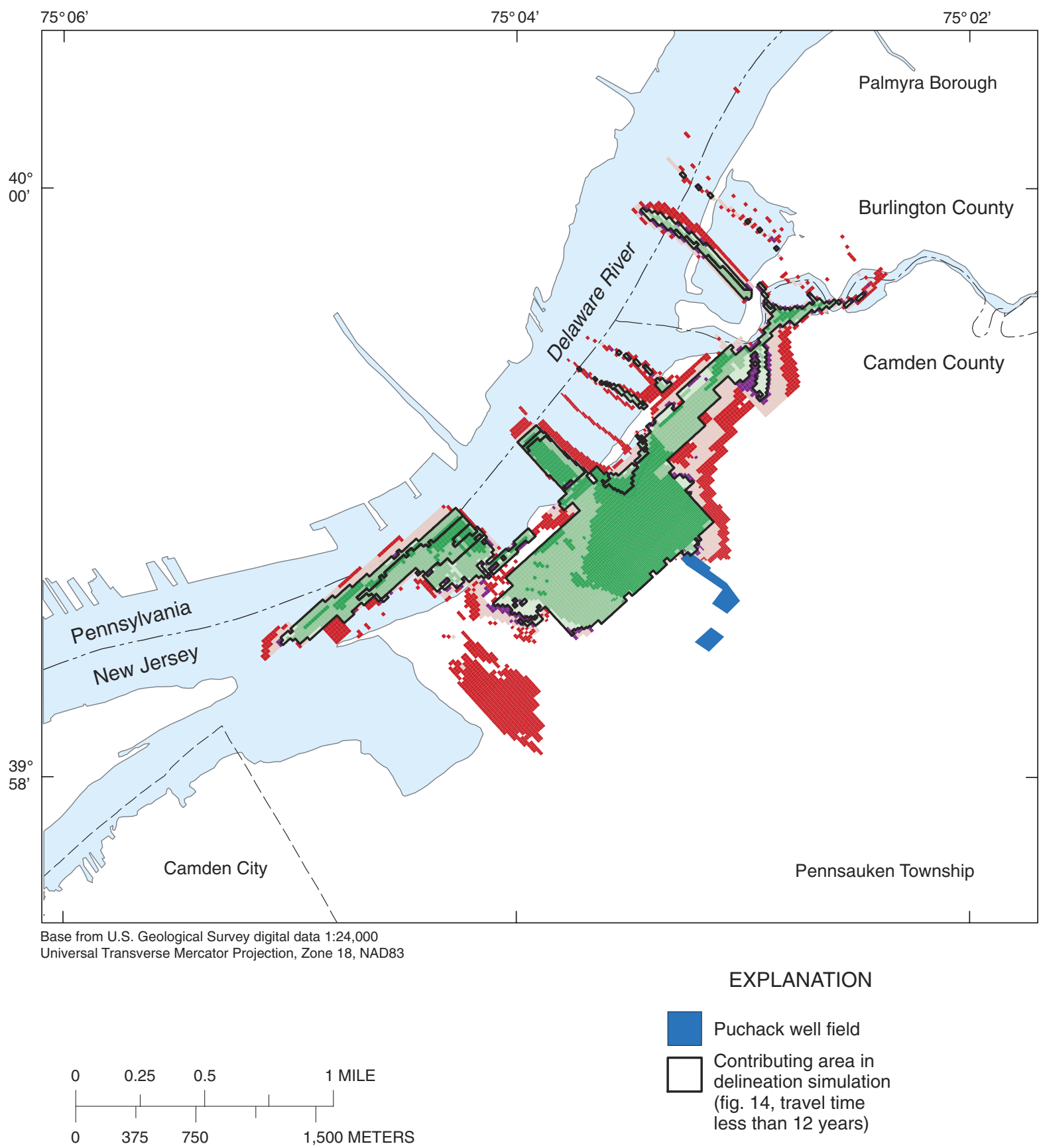

Puchack well field

Contributing area in delineation simulation

(fig. 14, travel time less than 12 years)

Number of model runs in which area contributed flow (travel time less than 12 years)

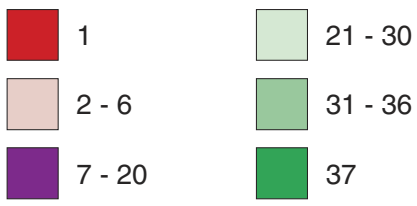

Figure 28. Number of model runs in which each area contributed flow to the Puchack well field in the uncertainty analysis, Pennsauken Township and vicinity, Camden County, New Jersey. 


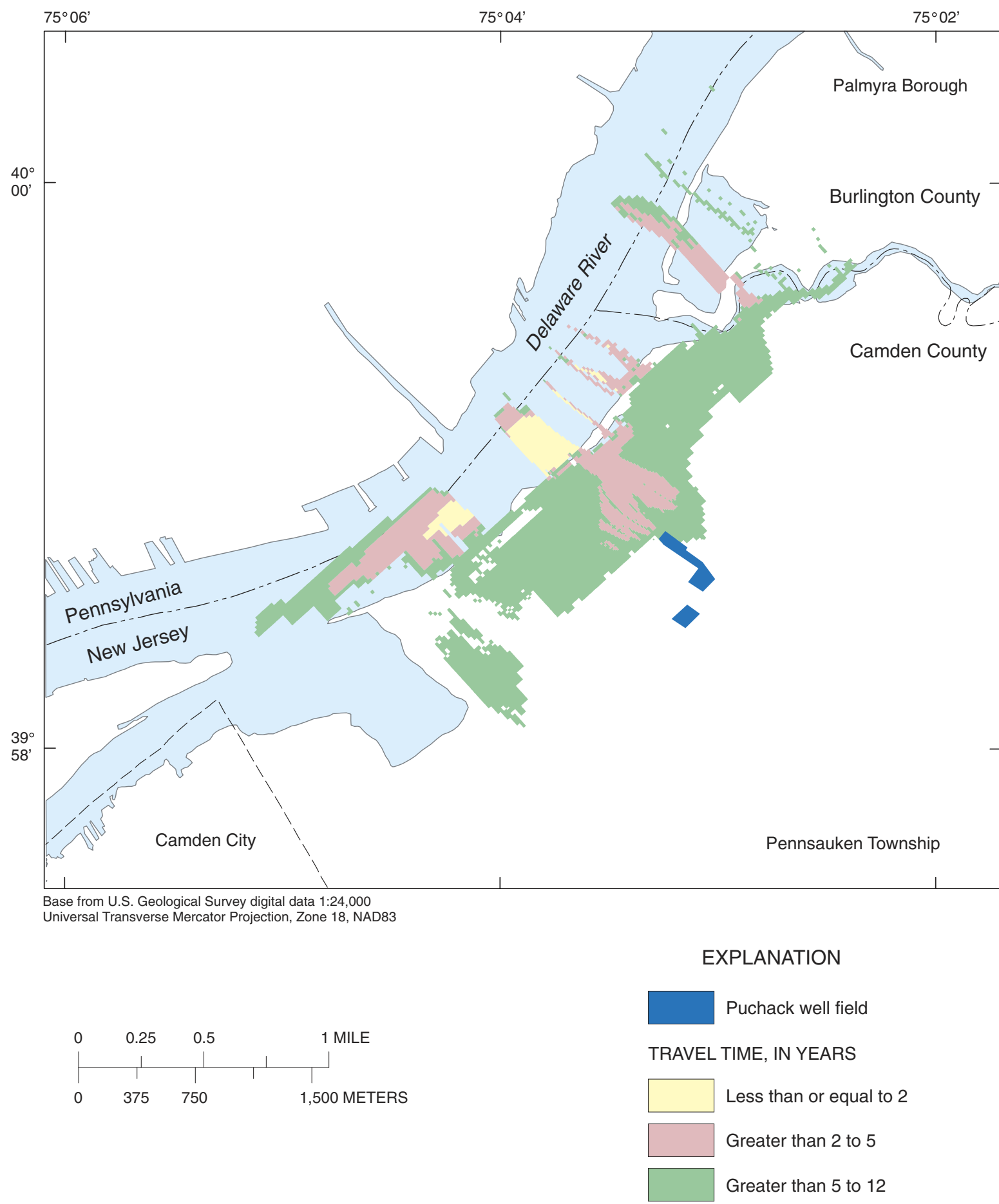

Figure 29. Simulated aggregate contributing area to the Puchack well field including the effects of uncertainty analysis, Pennsauken Township and vicinity, Camden County, New Jersey. 


\section{Summary}

The Well Head Protection Program in New Jersey requires delineation of Well Head Protection Areas (WHPA's). The NJDEP delineated WHPA's for all public community water-supply wells in New Jersey using standard methods. State guidelines also allow the use of a three-dimensional ground-water flow model where hydrologic conditions are complex.

A local ground-water flow model was developed that used a detailed 11-layer representation of the hydrogeologic units is used to account for local variations in hydrogeology. The local model was nested within a regional model to obtain boundary flows that used a more general 5-layer representation of the hydrogeology. The most important differences between the local 11-layer framework and the regional 5-layer framework included modifications to the representation of the confining unit between the Middle and Lower aquifers and differences in the variability of hydraulic properties in the Lower aquifer. The confining unit between the Middle and Lower aquifers is represented by three units in the local model-a relatively low-permeability layer (C-2a); a sandy unit (C-2AI) referred to as the Intermediate sand in this report; and an underlying layer that varies from clay to sand (C-2b). In many areas the lowermost of these units $(\mathrm{C}-2 \mathrm{~b})$ is relatively permeable and the Intermediate sand (C-2AI) is in direct connection with the Lower aquifer. The Lower aquifer is represented by three sand units in the local model-A-3a, A-3b, and A-3c. The lowermost of these units, A-3c, represents a very permeable gravel that is present throughout much of the model area.

Model-boundary conditions include recharge from precipitation, flow from the Delaware River and smaller tributary streams, and specified-flow boundaries. The simulated outcrop areas of the aquifers and confining units receive recharge at rates ranging from 0 to 14 inches per year, determined on the basis of zones representing the predominant land use. The Delaware River, the main surface-water body in the area, contributes a large volume of water to the ground-water-flow system and supplies much of the water withdrawn from the local public-supply wells. Streambed sediments underlying the Delaware River were characterized as having high, moderate, or low permeability. Calibrated riverbed hydraulic-conductivity values ranged from $0.00028 \mathrm{ft} / \mathrm{d}$ to $28 \mathrm{ft} / \mathrm{d}$. The model was nested within a larger regional model of the Potomac-RaritanMagothy aquifer system that was used to provide boundary conditions for the local model. Flows were input from the regional model along the lateral model boundaries and where the Upper aquifer is confined.

Horizontal hydraulic conductivities used in the calibrated model ranged from $50 \mathrm{ft} / \mathrm{d}$ for the Upper aquifer to $250 \mathrm{ft} / \mathrm{d}$ for the most productive (lowermost) unit in the Lower aquifer. Zones of vertical hydraulic conductivity were determined using geophysical logs. Vertical hydraulic conductivities in the confining units ranged from 0.001 to $0.5 \mathrm{ft} / \mathrm{d}$ and were highest in unit $\mathrm{C}-2 \mathrm{~b}$ overlying the Lower aquifer.
The local ground-water flow model was calibrated using a steady-state simulation of average withdrawals during January-March 1998. The model-calibration target was water levels measured in March 1998. Near the Puchack well field, the simulated heads at the wells generally were within $1 \mathrm{ft}$ of the measured heads in both the Middle and Lower aquifers. In the Lower aquifer, residuals were larger in areas distant from the Puchack well field. Differences between simulated and observed gradients across confining units generally were within $\pm 0.5 \mathrm{ft}$.

The model used in calibration was modified to meet NJDEP guidelines for delineating contributing areas in complex hydrogeologic settings. These modifications included rediscretizing the model grid and preparing the water-use data set for use in delineation. Contributing areas to the Puchack well field were delineated using particle tracking. Estimates of porosity of 20 percent for aquifer units and 25 percent for confining units were used for particle-tracking analysis.

The contributing area for the Puchack well field is affected by withdrawals from nearby well fields. The City of Camden Water Department Morris/Delair well field is located between the Puchack well field and the Delaware River. A large percentage of the flow to the Morris/Delair wells is derived from the Delaware River. Consequently, the Puchack well field receives flow from the Delaware River only from a small strip between the Morris and Delair well fields and from areas south of the Morris/Delair well field.

An uncertainty analysis was conducted to demonstrate the effects of changes in the model-input values on the contributing area to the Puchack well field. For this analysis, the values of the model parameters were varied individually. Where possible, the values of 36 variables were adjusted until simulated heads changed $\pm 5 \mathrm{ft}$ from the calibrated-model heads (using the 5 - $\mathrm{ft}$ model-calibration criterion for heads). Input data that were adjusted but to which the 5-ft change criterion was not applicable were related to withdrawals, uniform recharge, and porosity.

Porosity has the greatest effect on the size and shape of the contributing areas for each travel-time tier. Decreasing the porosity to 15 percent in aquifers and 20 percent in confining units expanded the size of the contributing area. Likewise, an increase in recharge decreased the area contributing flow from the Delaware River, whereas a decrease in recharge increased the contribution from the river.

The results of the 36 uncertainty-analysis simulations and the delineation contributing area were combined to determine the aggregate contributing area to the Puchack well field. Variations in the contributing area to the Puchack well field resulting from changes in model parameters are relatively small. An aggregate contributing area, defined as any zone that contributed flow to the Puchack well field within the specified 12-year travel time, was delineated. The "tiers" of this contributing area (0-2, >2-5, and $>5-12$ years) were assigned by the model run that produced the shortest travel time to the Puchack well field. Because decreasing porosity had the larg- 
est effect on the tiers in the contributing areas, the final aggregate contributing area was most similar to that resulting from the uncertainty run in which the porosity in both the aquifers and confining units was decreased.

\section{Acknowledgments}

The authors thank Robert Gallagher and Akshay Pariakh of the NJDEP for information about contamination at the Puchack well field. Robert Nicholson of the USGS and Steven Spayd of the New Jersey Geological Survey provided technical input on contributing-area delineations. Alison Gordon of the USGS assisted with the uncertainty analysis.

\section{Literature Cited}

Anderson, M.P., and Woessner, W.W., 1991, Applied groundwater modeling: Simulation of flow and advective transport: San Diego, Academic Press, 381 p.

Duran, P.B., 1986, Distribution of bottom sediments and effects of proposed dredging in the ship channel of the Delaware River between Northeast Philadelphia, Pennsylvania, and Wilmington, Delaware, 1984: U.S. Geological Survey Hydrologic Atlas 697, 1 sheet, scale 1:48,000.

Farlekas, G.M., Nemickas, Bronius, and Gill, H.E., 1976, Geology and ground-water resources of Camden County, New Jersey: U.S. Geological Survey Water-Resources Investigations Report 76-76, 146 p.

Ground Water Associates, Inc., 1995, 30-Day aquifer test for evaluation of induced groundwater recharge, Delaware Garden well No. 1: Bridgewater, N.J., Ground Water Associates, Inc., unpaginated.

Harbaugh, A.W., and McDonald, M.G., 1996, User's documentation for MODFLOW-96, an update to the U.S. Geological Survey modular finite-difference ground-water flow model: U.S. Geological Survey Open-File Report 96-485, $56 \mathrm{p}$.

Heath, R.C., 1983. Basic ground-water hydrology: U.S. Geological Survey Water-Supply Paper 2220, 84 p.

Leake, S.A., and Lilly, M.R., 1997, Documentation of a computer program (FHB1) for assignment of transient specified-flow and specified-head boundaries in applications of the modular finite-difference ground-water flow model (MODFLOW): U.S. Geological Survey Open-File Report 97-571, $50 \mathrm{p}$.
Martin, Mary, 1998, Ground-water flow in the New Jersey Coastal Plain: U.S. Geological Survey Professional Paper 1404-H, 146 p.

Navoy, A.S., and Carleton, G.B., 1995, Ground-water flow and future conditions in the Potomac-Raritan-Magothy aquifer system, Camden area, New Jersey: New Jersey Geological Survey Report GSR 38, 184 p.

New Jersey Department of Environmental Protection, 1996, New Jersey geographic information system: Trenton, N.J., New Jersey Department of Environmental Protection, CD-ROM series 1, v. 2.

Orzol, L.L., 1997, User's guide for MODTOOLS: Computer programs for translating data of MODFLOW and MODPATH into geographic information system files: U.S. Geological Survey Open-File Report 97-240, 86 p.

Owens, J.P., and Minard, J.P., 1979, Upper Cenozoic sediments of the Lower Delaware Valley and the northern Delmarva Peninsula, New Jersey, Pennsylvania, Delaware, and Maryland: U.S. Geological Survey Professional Paper 1067-D, 47 p.

Pollock, D.W., 1994, User's guide for MODPATH/MODPATH-PLOT, version 3: A particle-tracking post-processing package for MODFLOW, the U.S. Geological Survey finite-difference ground-water flow model: U.S. Geological Survey Open-File Report 94-464, 6 chap.

Spayd, S.E., and Johnson, S.W., 2003, Guidelines for delineation of well head protection areas in New Jersey: Trenton, N.J., New Jersey Department of Environmental Protection, New Jersey Geological Survey, 30 p.

Walker, R.L., 2001, Effects of pumping on ground-water flow near water-supply wells in the Lower Potomac-Raritan aquifer, Pennsauken Township, Camden County, New Jersey: U.S. Geological Survey Water-Resources Investigations Report 00-4012, 12 p.

Walker, R.L., and Jacobsen, E.J., 2004, Reconnaissance of hydrogeology and ground-water quality, Pennsauken Township and vicinity, Camden County, New Jersey, 1996-98: U.S. Geological Survey Water-Resources Investigations Report 03-4247, 102 p.

Zapecza, O.S., 1989, Hydrogeologic framework of the New Jersey Coastal Plain: U.S. Geological Survey Professional Paper 1404-B, 49 p., 24 pl. 
Table 1. Well-construction data for wells used in the ground-water flow model, Pennsauken Township and vicinity, Camden County, New Jersey.

[NJDEP, New Jersey Department of Environmental Protection; NGVD29, National Geodetic Vertical Datum of 1929; --, data not available]

\begin{tabular}{|c|c|c|c|c|c|c|c|}
\hline \multirow{2}{*}{$\begin{array}{c}\text { U.S. Geological } \\
\text { Survey well } \\
\text { number }\end{array}$} & \multirow{2}{*}{ Well name } & \multirow{2}{*}{$\begin{array}{l}\text { NJDEP well } \\
\text { permit number }\end{array}$} & \multirow{2}{*}{$\begin{array}{l}\text { Aquifer } \\
\text { code }^{1}\end{array}$} & \multirow{2}{*}{$\begin{array}{l}\text { Altitude of land } \\
\text { surface }^{2} \\
\text { (feet above } \\
\text { NGVD29) }\end{array}$} & \multirow{2}{*}{$\begin{array}{l}\text { Depth of well } \\
\text { (feet below } \\
\text { land surface) }\end{array}$} & \multicolumn{2}{|c|}{$\begin{array}{c}\text { Screened interval } \\
\text { (feet below land surface) }\end{array}$} \\
\hline & & & & & & Top & Bottom \\
\hline $5-1418$ & PSLF MW-12 & $31-26580$ & MRPAM & 18.2 & 33 & 13 & 33 \\
\hline 7-94 & CITY 16 & $31-01249$ & MRPAL & 23 & 179 & 149 & 179 \\
\hline $7-109$ & CAMDEN DIV 46 & $31-00162$ & MRPAL & 11 & 178 & 148 & 178 \\
\hline $7-111$ & CAMDEN DIV 50 & $31-03456$ & MRPAL & 9 & 170 & 139 & 170 \\
\hline $7-319$ & 1R/BROWNING 1A & $31-05641$ & MRPAM & 15 & 152 & 132 & 152 \\
\hline $7-320$ & WOODBINE 1 & $31-04642$ & MRPAL & 69 & 285 & 245 & 285 \\
\hline $7-325$ & BROWNING RD 2 & $31-03987$ & MRPAL & 25 & 240 & 207 & 237 \\
\hline $7-332$ & MARION 2 & $31-04641$ & MRPAL & 72 & 258 & 223 & 258 \\
\hline $7-335$ & MARION 1 & $31-02915$ & MRPAL & 61 & 278 & 243 & 278 \\
\hline $7-341$ & DELA GARDEN 2 & $31-01417$ & MRPAL & 45.3 & 145 & 115 & 145 \\
\hline $7-342$ & DELA GARDEN 1A & $31-05228$ & MRPAL & 28 & 139 & 109 & 139 \\
\hline $7-344$ & PARK AVE REP 4 & -- & MRPAL & -- & 178 & 153 & 178 \\
\hline $7-345$ & PARK AVE 5 & 31-00011 & MRPAL & 17 & 288 & 248 & 288 \\
\hline $7-346$ & PARK AVE 3A & -- & MRPAL & 30 & 260 & 210 & 260 \\
\hline $7-347$ & PARK AVE 4 & -- & MRPAL & 20 & 181 & 146 & 181 \\
\hline $7-348$ & MPWC PARK AVE 3 & $31-03534$ & MRPAL & 25 & 275 & 240 & 275 \\
\hline $7-349$ & PARK AVE 1 & $31-00010$ & MRPAL & 8 & 270 & 240 & 270 \\
\hline $7-350$ & PARK AVE 2 & $51-00064$ & MRPAL & 12 & 257 & 232 & 257 \\
\hline $7-358$ & PUCHACK 6 & $31-05450$ & MRPAL & 47.5 & 220 & 170 & 220 \\
\hline $7-359$ & PUCHACK 5 & $51-00059$ & MRPAL & 27.8 & 208 & 181 & 204 \\
\hline $7-363$ & PUCHACK 2 & $51-00057$ & MRPAL & 13.8 & 170 & 124 & 164 \\
\hline $7-366$ & PUCHACK 1 & $51-00056$ & MRPAL & 12.2 & 140 & 107 & 137 \\
\hline $7-367$ & PUCHACK 3 & $51-00058$ & MRPAL & 13.6 & 176 & 139 & 176 \\
\hline $7-368$ & DELAIR 1 & $51-00053$ & MRPAL & 10 & 138 & 106 & 126 \\
\hline $7-369$ & DELAIR 2 & $51-00054$ & MRPAL & 5 & 146 & 111 & 141 \\
\hline $7-370$ & DELAIR 3 & $51-00055$ & MRPAL & 6 & 132 & 107 & 127 \\
\hline $7-372$ & NATIONAL HWY 1 & $31-05110$ & MRPAL & 68 & 231 & 195 & 230 \\
\hline $7-373$ & MORRIS 6 & $51-00051$ & MRPAL & 5.9 & 138 & 98 & 133 \\
\hline $7-374$ & MORRIS 9/9N & $51-00076$ & MRPAL & 6.8 & 143 & 99 & 118 \\
\hline $7-375$ & MORRIS 8 & 31-00944 & MRPAL & 6 & 128 & 89 & 124 \\
\hline $7-377$ & MORRIS 7 & $51-00052$ & MRPAL & 6 & 120 & 85 & 120 \\
\hline $7-379$ & MORRIS 10 & $31-04251$ & MRPAL & 8.7 & 118 & 75 & 115 \\
\hline $7-382$ & MORRIS 4A & $31-04252$ & MRPAL & 6 & 134 & 95 & 130 \\
\hline $7-386$ & MORRIS 3A & $31-00945$ & MRPAL & 10 & 107 & 73 & 103 \\
\hline $7-387$ & MORRIS 2 & $51-51106$ & MRPAL & 6 & 123 & 93 & 123 \\
\hline $7-388$ & MORRIS 5 & -- & MRPAL & 5 & 115 & 80 & 115 \\
\hline $7-390$ & MORRIS 1 & $51-00050$ & MRPAL & 6 & 107 & 93 & 118 \\
\hline $7-528$ & PUCHACK 7 & $31-08526$ & MRPAL & 20.1 & 180 & 140 & 180 \\
\hline $7-530$ & 4R-A/PARK AVE 6 & $31-14564$ & MRPAL & 40 & 270 & 240 & 270 \\
\hline $7-536$ & TW-3-79 & $31-15369$ & MRPAL & 10 & 117 & 85 & 115 \\
\hline
\end{tabular}


Table 1. Well-construction data for wells used in the ground-water flow model, Pennsauken Township and vicinity, Camden County, New Jersey.-Continued.

[NJDEP, New Jersey Department of Environmental Protection; NGVD29, National Geodetic Vertical Datum of 1929; --, data not available]

\begin{tabular}{|c|c|c|c|c|c|c|c|}
\hline \multirow{2}{*}{$\begin{array}{l}\text { U.S. Geological } \\
\text { Survey well } \\
\text { number }\end{array}$} & \multirow{2}{*}{ Well name } & \multirow{2}{*}{$\begin{array}{l}\text { NJDEP well } \\
\text { permit number }\end{array}$} & \multirow{2}{*}{$\begin{array}{l}\text { Aquifer } \\
\text { code }^{1}\end{array}$} & \multirow{2}{*}{$\begin{array}{l}\text { Altitude of land } \\
\text { surface }{ }^{2} \\
\text { (feet above } \\
\text { NGVD29) }\end{array}$} & \multirow{2}{*}{$\begin{array}{l}\text { Depth of well } \\
\text { (feet below } \\
\text { land surface) }\end{array}$} & \multicolumn{2}{|c|}{$\begin{array}{c}\text { Screened interval } \\
\text { (feet below land surface) }\end{array}$} \\
\hline & & & & & & Top & Bottom \\
\hline $7-537$ & TW-4-79 & -- & MRPAL & 10 & 128.33 & 97 & 128.33 \\
\hline $7-538$ & TW-5-79 & -- & MRPAL & 10 & 129 & 80 & 110 \\
\hline $7-540$ & TW-7-79 & $31-14569$ & MRPAL & 10 & 141 & 98 & 138 \\
\hline $7-545$ & MORRIS 11 & $31-15745$ & MRPAL & 15.3 & 149 & 102 & 144 \\
\hline $7-547$ & 54 & $31-18944$ & MRPAL & 35 & 200 & 155 & 195 \\
\hline $7-560$ & WOODBINE 2 & $31-14563$ & MRPAL & 58 & 226 & 196 & 226 \\
\hline $7-568$ & LANDFILL 1 & -- & MRPAM & 24.9 & 60 & 59 & 60 \\
\hline $7-571$ & LANDFILL 4 & -- & MRPAM & 24.6 & 48 & 47 & 48 \\
\hline $7-586$ & MORRIS 12 & $31-16814$ & MRPAL & 10 & 122 & 86 & 117 \\
\hline $7-587$ & MORRIS 13 & $31-16813$ & MRPAL & 10 & 135 & 90 & 130 \\
\hline $7-597$ & 55 & $31-20270$ & MRPAL & 11 & 176 & 136 & 176 \\
\hline $7-602$ & NATIONAL HWY 2 & 31-19207 & MRPAL & 35 & 206 & 182 & 206 \\
\hline $7-724$ & CLEVELAND AVE PW 53 & $31-18947$ & MRPAL & 32 & 194 & 154 & 194 \\
\hline $7-848$ & BISHOP EUSTACE PREP & $31-17884$ & MRPAM & 25 & 150 & 135 & 150 \\
\hline $7-851$ & CAMDEN CITY MW-1A & $31-37328$ & MRPAL & 73.6 & 140.94 & 130.94 & 140.94 \\
\hline $7-852$ & CAMDEN CITY MW-1B & $31-37329$ & MRPAM & 73.7 & 103.8 & 93.8 & 103.8 \\
\hline $7-853$ & CAMDEN CITY MW-2A & $31-37326$ & MRPAL & 57.4 & 174 & 164 & 174 \\
\hline $7-854$ & CAMDEN CITY MW-2B & $31-37327$ & MRPAM & 57.2 & 120 & 110 & 120 \\
\hline $7-855$ & CAMDEN CITY MW-4A & $31-37359$ & MRPAL & 54.9 & 202 & 192 & 202 \\
\hline $7-856$ & CAMDEN CITY MW-4B & $31-37360$ & MRPAM & 54.7 & 86 & 76 & 86 \\
\hline $7-906$ & PUCHACK MW-1D & $31-51230$ & MRPAL & 38.9 & 177 & 162 & 172 \\
\hline $7-907$ & PUCHACK MW-1S & $31-51229$ & MRPAM & 39.0 & 61 & 51 & 56 \\
\hline $7-908$ & PUCHACK MW-1M & $31-51228$ & MRPAL & 39.0 & 100 & 85 & 95 \\
\hline $7-909$ & PUCHACK MW-2M & $31-51226$ & MRPAL & 31.6 & 103 & 88 & 98 \\
\hline $7-910$ & PUCHACK MW-2D & $31-51227$ & MRPAL & 30.8 & 155 & 140 & 150 \\
\hline $7-911$ & PUCHACK MW-3M & $31-51222$ & MRPAM & 78.4 & 138 & 128 & 133 \\
\hline $7-912$ & PUCHACK MW-3D & $31-51223$ & MRPAL & 78.8 & 287 & 272 & 282 \\
\hline $7-913$ & PUCHACK MW-4M & $31-51224$ & MRPAM & 60.6 & 123 & 108 & 118 \\
\hline $7-914$ & PUCHACK MW-4I & $31-52598$ & MRPAL & 60.2 & 201 & 186 & 196 \\
\hline $7-915$ & PUCHACK MW-4D & $31-51225$ & MRPAL & 60.6 & 260 & 245 & 255 \\
\hline $7-916$ & PUCHACK MW-5M & $31-51695$ & MRPAM & 35.8 & 78 & 63 & 73 \\
\hline $7-917$ & PUCHACK MW-5I & $31-52597$ & MRPAL & 35.5 & 135 & 120 & 130 \\
\hline $7-918$ & PUCHACK MW-5D & $31-51696$ & MRPAL & 35.6 & 190 & 175 & 185 \\
\hline $7-919$ & PUCHACK MW-6M & $31-51697$ & MRPAM & 26.4 & 74 & 59 & 69 \\
\hline $7-920$ & PUCHACK MW-6D & $31-51698$ & MRPAL & 26.4 & 193 & 178 & 188 \\
\hline $7-921$ & PUCHACK MW-7D & $31-51699$ & MRPAL & 58.2 & 202 & 187 & 197 \\
\hline $7-922$ & PUCHACK MW-7M & $31-51700$ & MRPAM & 58.0 & 110.5 & 95.5 & 105.5 \\
\hline $7-923$ & PUCHACK MW-8M & $31-51702$ & MRPAM & 23.7 & 55 & 40 & 50 \\
\hline $7-924$ & PUCHACK MW-8D & $31-51701$ & MRPAL & 23.7 & 165 & 150 & 160 \\
\hline $7-925$ & PUCHACK MW-9S & $31-51705$ & MRPAM & 22.2 & 49 & 36 & 46 \\
\hline
\end{tabular}


Table 1. Well-construction data for wells used in the ground-water flow model, Pennsauken Township and vicinity, Camden County, New Jersey.-Continued.

[NJDEP, New Jersey Department of Environmental Protection; NGVD29, National Geodetic Vertical Datum of 1929; --, data not available]

\begin{tabular}{|c|c|c|c|c|c|c|c|}
\hline \multirow{2}{*}{$\begin{array}{l}\text { U.S. Geological } \\
\text { Survey well } \\
\text { number }\end{array}$} & \multirow{2}{*}{ Well name } & \multirow{2}{*}{$\begin{array}{l}\text { NJDEP well } \\
\text { permit number }\end{array}$} & \multirow{2}{*}{$\begin{array}{l}\text { Aquifer } \\
\text { code }^{1}\end{array}$} & \multirow{2}{*}{$\begin{array}{l}\text { Altitude of land } \\
\text { surface } \\
\text { (feet above } \\
\text { NGVD29) }\end{array}$} & \multirow{2}{*}{$\begin{array}{l}\text { Depth of well } \\
\text { (feet below } \\
\text { land surface) }\end{array}$} & \multicolumn{2}{|c|}{$\begin{array}{c}\text { Screened interval } \\
\text { (feet below land surface) }\end{array}$} \\
\hline & & & & & & Top & Bottom \\
\hline $7-926$ & PUCHACK MW-9M & $31-51704$ & MRPAM & 22.5 & 70 & 55 & 65 \\
\hline $7-927$ & PUCHACK MW-9D & $31-51703$ & MRPAL & 23.3 & 181 & 166 & 176 \\
\hline $7-928$ & PUCHACK MW-10M & $31-51900$ & MRPAM & 43.6 & 91 & 76 & 86 \\
\hline $7-929$ & PUCHACK MW-10D & $31-51901$ & MRPAL & 43.6 & 202 & 187 & 197 \\
\hline $7-930$ & PUCHACK MW-12M & $31-51906$ & MRPAL & 33.7 & 170 & 155 & 165 \\
\hline $7-931$ & PUCHACK MW-14 & $31-52706$ & MRPAL & 56.3 & 133 & 118 & 128 \\
\hline $7-932$ & DELA GARDEN R-1 & $31-43420$ & MRPAL & 28.7 & 145 & 125 & 145 \\
\hline $7-933$ & HOLMAN ENT P-47-D & $31-45075$ & MRPAL & 28.4 & 182 & 177 & 182 \\
\hline $7-934$ & HOLMAN ENT P-45-D & $31-45076$ & MRPAM & 28.5 & 120 & 100 & 120 \\
\hline $7-940$ & SUPER TIRE MW-2D & $31-35902$ & MRPAM & 36.6 & 75 & 55 & 75 \\
\hline $7-943$ & KING ARTHUR MW-5S & $31-36280$ & MRPAM & 64.7 & 91 & 71 & 91 \\
\hline $7-944$ & KING ARTHUR MW-5D & $31-36279$ & MRPAL & 64.7 & 140 & 125 & 140 \\
\hline $7-948$ & GSM MW-11 & $31-33572-1$ & MRPAM & 34.0 & 63 & 53 & 63 \\
\hline $7-954$ & PSLF MW-7 & -- & MRPAM & 71.4 & 115.08 & 95.17 & 115.08 \\
\hline $7-957$ & PSLF MW-3D & $31-26142-6$ & MRPAL & 60.6 & 177 & 157 & 177 \\
\hline $7-958$ & PSLF MW-5 & $31-18183$ & MRPAM & 72.3 & 109.75 & 89.75 & 109.75 \\
\hline $7-959$ & PSLF MW-5D & $31-26143-4$ & MRPAL & 72 & 187 & 167 & 187 \\
\hline $7-960$ & PSLF MW-6 & $31-19602$ & MRPAM & 37.4 & 80.42 & 60.33 & 80.42 \\
\hline $7-961$ & PSLF MW-6D & $31-26141-8$ & MRPAL & 38.4 & 149 & 129 & 149 \\
\hline $7-962$ & PSLF MW-2 & $31-17781$ & MRPAM & 70.0 & 100 & 90 & 100 \\
\hline $7-963$ & PSLF MW-13 & $31-29056-6$ & MRPAM & 17.1 & 44.24 & 29.24 & 44.24 \\
\hline $7-964$ & PSLF MW-11 & $31-24601-1$ & MRPAM & 19.0 & 30 & 10 & 30 \\
\hline $7-965$ & PSLF MW-11D & $31-26140-0$ & MRPAL & 18.7 & 105 & 85 & 105 \\
\hline $7-1070$ & MORRIS 14 & $31-56691$ & MRPAL & 11 & 125 & 93 & 120 \\
\hline $7-1071$ & MORRIS 15 & $31-57430$ & MRPAL & 12 & 128 & 93 & 123 \\
\hline
\end{tabular}

${ }^{1}$ Aquifer code: MRPAM, Middle Potomac-Raritan-Magothy aquifer; MRPAL, Lower Potomac-Raritan-Magothy aquifer.

${ }^{2}$ Values of altitude of land surface listed as whole numbers were determined by visual inspection of a 1:24,000-scale topographic map or by altimeter. Values listed to the tenths place were determined by level measurement. 
For additional information, write to:

\section{U.S. Geological Survey}

Water Resources Division

New Jersey District

Mountain View Office Park

810 Bear Tavern Rd., Suite 206

West Trenton, NJ 08628

or visit our Web site at:

http://nj.water.usgs.gov

To request numerical model input data sets in electronic form, contact the information officer, U.S. Geological Survey, New Jersey District, or call (609) 771-3900. 